\title{
Pig genetics : a review ${ }^{(1)}$
}

\author{
L. OLLIVIER and P. SELLIER \\ I.N.R.A., Station de Génétique quantitative et appliquée, \\ Centre de Recherches zootechniques, F 78350 Jouy-en-Josas
}

\begin{abstract}
Summary
A general review on pig genetics is given. The main topics covered are : karyotype and chromosomal abnormalities, coat colour, hereditary defects and disorders, disease resistance, immunogenetics, biochemical polymorphisms, linkages and syntenies, and quantitative traits of economic importance. As regards the latter field, special emphasis is put on the known influences of marker genes on performance traits. Lists of genes controlling coat colour, blood groups (erythrocyte antigens), and electrophoretic variants of blood serum proteins and blood cell enzymes are tabulated. A list of 29 genetic abnormalities which can be considered as probably monogenic in the pig is also given. The total number of presently identified loci is around 100 .
\end{abstract}

\section{Introduction}

Domestication of the pig dates back to the Neolithic age and, recently, remains of domestic pigs dated 7000 B.C. have also been found in China. Pig was considered as sacred in the ancient world and it still is in some countries like New-Guinea. Pigs have also been used in England to point for game and in France to root for truffles. Since modern times the pig has mainly been used to produce lard, fresh meat (pork) or various kinds of processed meat (bacon, ham, etc.). The increased demand for meat has seen the recent development of breeds with high lean meat content. Pig is also nowadays used as a laboratory animal in biomedical research (Pond \& Houpt, 1978), owing to its close physiological similarities to man, and several strains of miniature pigs have been developed for that purpose. The total world pig population was estimated to nearly eight hundred millions heads in 1981. Asia produces the largest number followed by Europe, North America, the U.S.S.R., South America, Africa and Oceania. The number of breeds or local varieties exceeds 300 : see MASON (1969).

(1) This review was originally intended as a chapter of the Handbook of Mammalian Genetics to be published by Garland Publishing, New York. We are grateful to the Editor (Dr Roy Robinson, Ealing, U.K.) for his permission to publish a revised version of the chapter separately, in view of the delay in the preparation of the book.

Cette revue bibliographique devait constituer un chapitre du livre Handbook of Mammalian Genetics léditeur: Garland Publishing. New York). Par suite des retards survenus dans la préparation de ce livre, l'Editeur scientifique ( $D^{\mathrm{r}}$ Robinson, Ealing, G.B.) nous a autorisés à publier séparément une nouvelle version du texte. Nous lui en exprimons ici notre reconnaissance. 
The present-day domestic pig (Sus scrofa var. domestica) has evolved from the European wild boar (Sus scrofa) that was crossed with the Chinese pig (Sus vittatus). The species is highly prolific. With a gestation length of 114 days and a litter size of 8-12 piglets, a sow is able to produce regularly around 20 slaughter pigs per year from the age of one year up to that of 6-7 years in the most favourable cases.

\section{TABLE 1}

A list of reviews on pig genetics (not including the reviews on quantitative performance traits).

Liste de revues bibliographiques sur la génétique du Porc (caractères quantitatifs exclus).

\begin{tabular}{l|l|l}
\hline \hline Year & \multicolumn{1}{|c|}{ Authors } & \multicolumn{1}{c}{ Coverage } \\
\hline 1918 & WRIGHT & Colour \\
1931 & KOSSWIG and OSSENT & Colour \\
1936 & SCHMIDT and LAUPRECHT & Colour \\
1938 & SMITH, ROBINSON and BRYANT & General \\
1940 & CASTLE & Colour \\
1945 & HETZER & Colour \\
1957 & KOCH, FISCHER and SCHUMANN & Abnormalities \\
1959 & HANSET & Colour \\
1961 & BERGE & Colour \\
1962 & ANDRESEN & Blood groups \\
1964 & JOHANSSON & Abnormalities \\
1968 & BUSCHMANN and SCHMID & Serum proteins \\
1968 & SEARLE & Colour \\
1969 & HULOT & Chromosomes \\
1971 & LARSEN & Blood groups and polymorphic proteins \\
1974 & WIESNER and WILLER & Abnormalities \\
1975 & RASMUSEN & Blood groups \\
1975 & MCDERMID, AGAR and CHAI & Red cell enzymes \\
1975 & WIDAR, ANSAY and HANSET & Enzymes \\
1977 & IVANYI & Histocompatibility \\
1978 & HUSTON, SAPERSTEIN, SCHONEWEIS and LEIPOLD & Abnormalities \\
1978 & AGERGAARD and NIELSEN & Blood groups \\
1978 & HYLDGAARD-JENSEN and JøRGENSEN & Serum proteins and red cell enzymes \\
1979 & GAHNE & Immunogenetics \\
& and biochemical genetics \\
1979 & OISHI & Immunogenetics \\
1981 & FECHHEIMER & and biochemical genetics \\
1981 & HRUBAN & Cytogenetics \\
\hline & & Immunogenetics \\
\hline & & \\
\hline & & \\
\hline & & \\
& &
\end{tabular}

As indicated in table 1, several reviews on pig genetics have already been published, many devoted to coat colour. A very detailed review of genetic abnormalities has been published by Косн, Fischer \& SchumanN (1957), to which we shall frequently refer in this article. A number of reviews have recently been devoted to the newer fields of immunogenetics and biochemical polymorphism. No general review on pig genetics appears to have been published since The genetics of the pig by SMITH, Robinson \& Bryant (1938). 


\section{Karyotype}

Up to 1960 , the pig chromosome number was an object of controversy. SмIтH et al. (1938) however accepted $2 \mathrm{n}=38$ as a working hypothesis, a number on which there is now complete agreement, as indicated by Hulor (1969), to whom we owe a detailed historical review of techniques and chromosome number estimations between 1913 and 1968. But there has been some confusion on the description and arrangement of chromosomes even after the advent of the "banding " techniques in 1970, which, in principle, permit a precise identification of each chromosome. An up-to-date description and identification of the pig chromosomes is given by HANSEN (1980) and LIN et al. (1980), on the basis of relative length and several banding patterns.

Two polymorphisms in C-banding pattern have recently been reported in the pig by Christensen \& SMEDEgARd $(1978,1979)$ : these variants are inherited in a regular Mendelian way, as most of similar variants in humans. Chromosomal polymorphism appears to be a widespread phenomenon in pigs (HANSEN-Melander \& Melander, 1974 ; Veijalainen \& Rimaila-Pärnänen, 1978 ; Sysa, 1980).

The chromosome complement of some european wild pigs, with 36 chromosomes, includes a submetacentric chromosome which is considered as homologous to two telocentric chromosomes of the domestic pig, these two chromosomes being involved in a Robertsonian translocation (e.g. MC FEE et al., 1966 ; POPESCU et al., 1980). MC FEE \& BANNER (1969) have shown that this translocation behaves as a simple Mendelian character, without any incidence on fertility or visible traits. In the Netherlands, a particular strain of wild pigs has been shown to carry three different chromosome numbers, 36, 37 and 38, which would indicate the existence of a balanced chromosomal polymorphism, similar to that found in other mammalian species (BosMA, 1976). Bosma suggests that the original chromosomal number in the wild boar was indeed 38 and has been reduced to 36 in modern wild populations as a consequence of a centric fusion of two telocentrics into one submetacentric. In fact, two types of such a fusion, involving three different telocentric chromosomes, have been shown to occur in wild boars of the U.S.S.R. (Tikhonov \& Troshina, 1975).

Pig chromosomal abnormalities have been reviewed by HuLot (1969) and, more recently, by Gustavsson (1980), FechHeimer (1981) and Popescu (1982). Most studies have been done in connection with reproductive abnormalities and they will be reviewed below in the corresponding section.

\section{Coat colour}

\section{A. Description of the main coloured types and breeds}

\section{Wild type}

The wild colour, similar to agouti in rodents, is characterized by a yellow subterminal band on an otherwise dark dorsal hair and also often by a variable colour intensity according to the body region. A particularity of the wild pig is that piglets at birth exhibit longitudinal stripes which gradually disappear later in life. This may also occur in some domestic breeds (e.g. Mangalitza). 


\section{Uniform black}

This type is exemplified by the English Large Black breed. It was also found in several local breeds which have by now disappeared, such as the German Cornwall, the French Gascon and a variety of the Mangalitza breed.

\section{Uniform red}

Two breeds show this colour, Duroc-Jersey and Tamworth, and also the new American breed Minnesota $n^{\circ}$ I. A red variety has also been reported in Mangalitza.

\section{Black spotting}

Black spots generally occur on a white background, but red hair in a variable amount may be mixed with white, up to a uniformly red background. Such a pattern is found in Spotted Poland-China, Gloucester Old Spot, Piétrain and Bayeux.

\section{Black with white points}

The coat is uniformly black with the exception of six white points (feet, tail and snout) in Berkshire and Poland-China.

\section{Belt}

Several breeds show a white belt of variable width and generally centered on the shoulders, against a background which is black in the following breeds, Wessex, Essex, Hampshire, Hannover-Braunschweig, Basque and Limousin, and red in Bavarian Landschwein, also called half-coloured as most of the anterior part of the body is white.

\section{White}

Two types of white coat exist, a shiny white with usually a white skin as in Large White (Yorkshire), Middle White, Chester White, Lacombe, Blanc de l'Ouest and the Landraces of various european countries, and a "dirty "white on a pigmented skin as in Mangalitza.

The asiatic breeds of pigs, as described by EPSTEIN (1969), also appear to fall in the same categories. Rarer types of colour have occasionally been reported and may be worth mentioning : sepia hair, sepia coat which is a mixture of white, dark and banded hair, and roan, a mixture of white and black hair. The blue colour, which consists of white hair on a black skin, has also sometimes been referred to as roan.

\section{B. Genetics of coat colour}

Table 2 summarizes the experimental work pertaining to the previously described main colour types in pigs and it shows that almost all possible combinations have been investigated in crossbreeding experiments. These, unfortunately, were not usually designed for studying colour inheritance, and not carried on long enough nor on a sufficient number of animals to allow definite conclusions to be reached. Therefore several points still remain obscure in pig coat colour inheritance. The first overall 


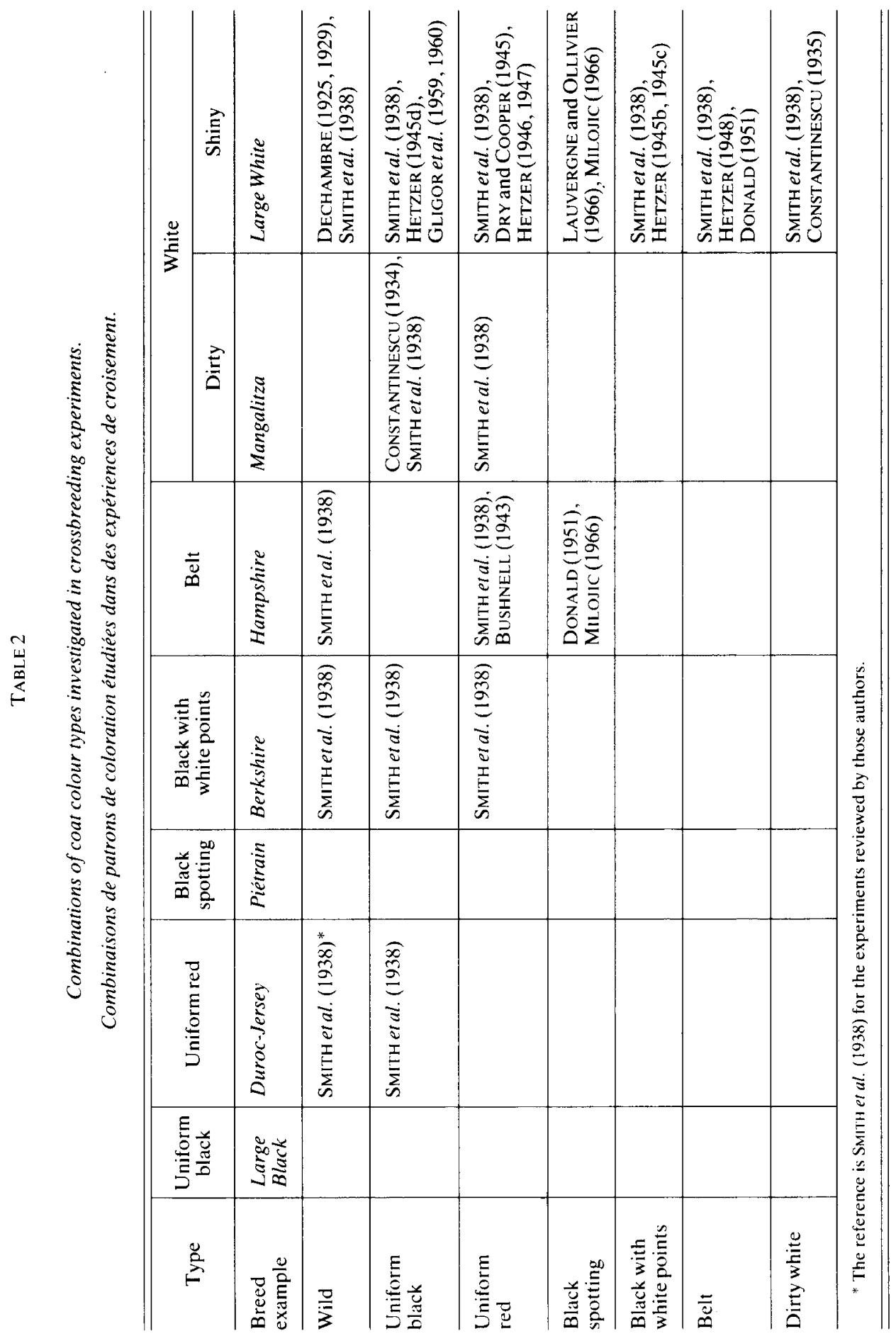


view of the subject was given by $W_{\text {RIGHT }}$ (1918). Early conclusions reached in America by Wentworth \& Lush (1923) and in Germany by Kosswig \& Ossent (1931, 1932, 1934) and by Kronacher \& OGRIzek (1932) have been summarized by Smith et al. (1938). But the major body of experimental data so far remains the series of papers by Hetzer, published from 1945 to 1954 . Searle (1968) discussed possible homologies between the colour genes of the pig and those of other mammalian species and we shall follow his order of presentation (see table 3 for summary).

\section{TABLE 3}

A list of coat colour genes in the pig, adapted from BERGE (1961) and SEARLE (1968).

Liste de gènes de coloration de la robe chez le Porc, adaptée de BERGE (1961) et SEARLE (1968).

\begin{tabular}{|c|c|c|}
\hline Loci & & Alleles \\
\hline A & $\begin{aligned} & A^{w} \\
\text { (1) } & A^{b} \\
& a \\
\text { (1) } & a^{s}\end{aligned}$ & $\begin{array}{l}\text { (agouti white belly) } \\
\text { (agouti badger face) } \\
\text { (non agouti) } \\
\text { (sepia) }\end{array}$ \\
\hline $\mathrm{C}$ & (1) $\begin{array}{ll} & C \\
c^{e}\end{array}$ & $\begin{array}{l}\text { (normal) } \\
\text { (extreme dilution }=\text { dirty white) }\end{array}$ \\
\hline $\mathrm{D}$ & $\begin{array}{l}D \\
\text { (1) } d^{s}\end{array}$ & $\begin{array}{l}\text { (normal) } \\
\text { (sepia) }\end{array}$ \\
\hline $\mathrm{E}$ & $\begin{array}{ll} & E^{d} \\
& E \\
& E^{p} \\
& e \\
\text { (1) } & e^{h}\end{array}$ & $\begin{array}{l}\text { (dominant black) } \\
\text { (normal) } \\
\text { (partial extension) } \\
\text { (red) } \\
\text { (white face) }\end{array}$ \\
\hline $\mathrm{R}$ & $\begin{array}{l}R \\
r\end{array}$ & $\begin{array}{l}\text { (normal) } \\
\text { (red-eye) }\end{array}$ \\
\hline I & $\begin{array}{ll} & I \\
& I^{d} \\
& i \\
\text { (1) } & i^{m}\end{array}$ & $\begin{array}{l}\text { (inhibition of colour) } \\
\text { (roan) } \\
\text { (coloured) } \\
\text { (dirty white) }\end{array}$ \\
\hline $\mathrm{Be}$ & $\begin{array}{l}B e \\
b e \\
\text { (1) } b e^{b}\end{array}$ & $\begin{array}{l}\text { (belt) } \\
\text { (self) } \\
\text { (half-coloured and possibly white face) }\end{array}$ \\
\hline
\end{tabular}

(1) Allelism not proven. 


\section{Wild colour (Agouti locus)}

From crosses reported by Spillman (1906), Fröhlich (1913), Wentworth \& LuSh (1923) and Kosswig \& Ossent (1931), wild colour appears to be dominant to the Berkshire black, but recessive to Hannover-Braunschweig black and to white. However, the segregation results observed in crosses between wild and red or black breeds are complex and various hypotheses had to be put forward by Kosswig \& Ossent (1931) in order to explain them. This is a consequence of epistatic relations, not yet well understood, between the agouti locus (A) and the other colour loci.

It can reasonably be assumed, with Berge (1961) and Searle (1968), that most domestic breeds carry the recessive non-agouti $(a)$ allele, though the wild allele $(A)$ may be present in some red breeds as the light-belly agouti pattern has been shown by LusH (1921) to appear in an $\mathrm{F}_{2}$ Berkshire $\times$ Duroc-Jersey. The Mangalitza breed is another exception in that respect, for wild type $F_{1}$ piglets may appear when Mangalitza is crossed with various other domestic breeds (Ossent, 1929 ; KosswiG \& Ossent, 1931 ; Constantinescu, 1933 ; Teodoreanu, 1935). In view of this, Kosswig \& OSSEnT (1931) assume that in Mangalitza the $A$ allele, which would be responsible for the juvenile striping pattern, is present at a high frequency. This is not accepted by Constantinescu (1933), Teodoreanu (1935) and Hetzer (1945 a), who consider that the juvenile stripes, a constant characteristic of Mangalitza, and the wild pattern are determined by genes at two different loci. On the other hand, the presence of juvenile stripes in white breeds, often visible as a "ghost pattern " (DECHAMBre, 1925), suggests that hair structure rather than pigmentation is involved in the phenomenon. Comparing wild coat colour between Papua New Guinea village pigs and the French wild boar, LAUVERGNE et al. (1982) think that another agouti pattern may exist besides the light-belly agouti of the previous authors : a kind of badger face pattern, with black belly and snout. The symbol they propose for light-belly agouti is $A^{w}$ ( $w$ for white) and they prove that this allele is dominant on $a$. The tentative symbol for the badger face variant could be $A^{b}$ ( $b$ for badger face).

\section{Brown and Albinism (B and $\mathrm{C}$ loci)}

No members of these two series were reported until recently, but according to LAUVERGne et al. (1982) a brown variant of eumelanin could exist in Papua New Guinea village pigs. Albinism is unknown in the pig, but SEARLE (1968) considers the dirty white colour of Mangalitza as possibly due to an allele of the $\mathrm{C}$ series, homologous with extreme dilution $c^{e}$ in other mammals.

\section{Dilution (D locus)}

A likely member of this series is, according to SEarle (1968), the recessive sepia factor observed by Mc PHEE et al. (1931), who describe this colour as due to a partial dilution of the black pigment and to a mixture of white, pigmented and banded hair. BERGE (1961) attributes it to an allele $\left(a^{s}\right)$ of the agouti locus.

\section{Extension (E locus)}

A series of three alleles at the $\mathrm{E}$ locus is well established. The alleles are, in HETZER's nomenclature, $E$ for uniform black, $E^{p}$ for black-spotting and $e$ for uniform red. The allelism of $E$ and $e$ has been shown in Large Black $\times$ Duroc crosses 
(Detlefson \& Carmichael, 1921) and confirmed in Hampshire $\times$ Duroc crosses by Bushnell (1943). It is also compatible with observations involving the Cornwall and the Bavarian breeds by KronACHER (1924). From those results, Large Black, Hampshire and Cornwall may be considered as EE, Duroc as ee, and Bavarian Landschwein as predominantly $e e$. Allelism between $E$ and $E^{p}$ may also be inferred from Large Black $\times$ Berkshire crosses (CARR-SAUnders, 1922), Berkshire $\times$ Cornwall crosses (Kosswig \& OsSENT, 1931) and from comparisons between Landrace $\times$ Large Black and Landrace $\times$ Poland-China (or Berkshire) crosses by HeTZer (1945 b, c, d), who also confirms (HETZER, 1946) the order of dominance $E / E^{p} / e$. It may thus be assumed that Berkshire and Poland-China are $E^{p} E^{p}$. The same genotype is found in the Piétrain breed (Lauvergne \& Ollivier, 1966 ; Milois, 1966). Thus the Berkshire (Poland-China) black is merely an extended form of black spotting. This was first suggested by WRIGHT (1918) and has later been confirmed by HETZER (1954) who showed that black spotting may be experimentally extended by selection. According to HANSET (1959), the origin of the Piétrain coat is the Berkshire, which was originally a spotted breed.

The existence of a fourth allele at the E locus is likely. Kosswig \& Ossent (1931) distinguish between a hypostatic black $(E)$ in Cornwall (or Large Black) and a dominant black $\left(E^{d}\right)$, epistatic over the other colours, in Hannover-Braunschweig (or Hampshire). This series of 4 alleles, $E^{d} / E / E^{p / e}$, is thus similar to that found in the guinea pig and the rabbit (SEARLE, 1968).

\section{Pink or Red-eye series ( $\mathrm{P}$ and $\mathrm{R}$ loci)}

According to SEarle (1968), no member of the P series is known, but the analogous (and linked) $\mathrm{R}$ locus (red-eye) of the rat seems to have an equivalent in the recessive autosomal gene $(r)$ shown by RoBERTS \& KRIDER (1949) to be responsible for the red-eye and dilution of the black pigment into a sepia colour, found in the Hampshire breed.

\section{White (I locus)}

White is the most frequent colour among the present domestic breeds of pigs, and, not surprisingly, crosses between white and coloured breeds have been the most investigated (see table 2). As early as 1906, SpILlman established the dominance of the white colour in a Tamworth $\times$ Yorkshire cross. On the basis of those results, WRIGHT (1918) assumed that white was due to two dominant genes, but, from later results, WENTWORTH \& LusH (1923) put forward the hypothesis of a single dominant gene. This was confirmed by Hetzer ( 1945 b, c, d) who called the gene $I$. Later results also showed independence between the I and the E colour loci (HETzER, 1946). White breeds, such as Yorkshire and Landrace, are generally homozygous for $I$, a gene which inhibits both black and yellow pigment production, and coloured breeds, such as Berkshire, Poland-China, Large Black, etc., are homozygous recessive $i$. A third allele, $I^{d}$, has been postulated by HeTzER (1948) in order to explain the occurrence of roans in some crosses between Landrace and Hampshire. $I^{d}$ would be recessive to and would have the same inhibitory effect on pigments as $I$ when $E^{p}$ is present, and it would give a roan phenotype (mixture of black and white hair) when $E$ is present. The "sapphire hog " described by MC LEAN (1914) probably presented the same roan character, originating from the white breeds used in its foundation. This $I^{d}$ gene, also present in the Créole pig of Guadeloupe (LAUVERGNe \& CANOPE, 1979), is possibly homologous to the genes for roan found in cattle and in horses (SEARLe, 1968). A fourth allele $i^{m}$ is assumed by BERGE (1961) 
as responsible for the recessive white of Mangalitza, the order of dominance being then at the I locus $I / I^{d} / \mathrm{i} / \mathrm{i}^{\mathrm{m}}$. This is not however accepted by SEArLe (1968) who considers the Mangalitza white as due to an allele at the $\mathrm{C}$ locus (see above).

\section{White Belt (Be locus)}

This pattern was first studied genetically by SpILLman (1907) who assumed it to be due to the complementary action of two genes. Durham (1921) is in favour of a major dominant gene, as also Olbrycht (1941) and Donald (1951). The latter authors however disagree on the explanation for the colour polymorphism observed in the Wessex Saddleback and Essex breeds, where the belt is variable in width and black pigs are reported to remain at a noticeable frequency in spite of their regular elimination by the breeders. For OlbRYcht (1944), belt width is essentially a polygenic character, whereas for DonaLD the narrow belt selected for by the breeders is an "unfixable » heterozygous genotype $\left(B e^{w} b e\right)$, black piglets being mainly bebe. According to BERGE (1961), the wide belt of the Hannover-Braunschweig would correspond to the homozygous $B e^{w} B e^{w}$, and the extension of the belt towards the front found in the half-coloured Bavarian Landschwein, which is recessive to uniform colour, would be due to a third allele $b e^{b}$ at the same locus, the order of dominance being $B e^{w} / b e / b e^{b}$. SEARLE (1968) however considers the dominant white saddle of Hampshire (analogous to belt in cattle) and the recessive half-coloured pattern (similar to belted in mouse) as two entities not proven to be allelic. This opinion is somewhat reinforced by the suggestions of a close linkage between the $E$ locus and the half-coloured pattern on one hand (KRONACHER, 1924) and of a loose linkage between the white belt factor and the E locus on the other hand (Bushnell, 1943). Searle (1968) also considers the white face pattern of the "Hereford hog " described by SMITH et al. (1938) as probably due to the same gene as the half-coloured pattern, whereas BERGE (1961) assumes an allele of the $\mathrm{E}$ series responsible for white face.

\section{Hair and skin}

The hereditary basis of hairlessness (hypotrichosis) has been established by Roberts \& Carrol (1931). This condition, which is to be distinguished from a similar one due to a deficiency of iodine, is due to a single autosomal recessive gene, which reduces the number of hair follicles.

Another type of hypotrichosis has been described by Meyer \& Drommer (1968). In their case an autosomal dominant gene is involved. This character is lethal, as homozygous hypotrichotic piglets die within 10 days. The vitality of heterozygous individuals is also reduced.

The woolly hair condition, frequently occurring in the Brazilian native breed Canastrao, has been studied by RHOAD (1934), who showed it to be determined by a single autosomal dominant gene, segregating independently from genes for coat colour and pattern. The data were insufficient to establish its independence from the recessive type of hairlessness, a factor which also was present in the same breed. 
Disturbances in the arrangement of the hair, known as whorls or " roses ", occur mainly along the spinal column. They have been explained by the complementary action of two dominant genes (NorDBY, 1932).

Several kinds of skin defects, of a hereditary nature, have been reported in the pig. A condition known as epitheliogenesis imperfecta is characterized by areas of missing epidermis of variable and irregular size. The condition is semi-lethal, as affected piglets usually die within three days but may survive if the abnormal area is small and the animal properly handled. The first case was reported by NordBy (1929) who considered the abnormality to be probably genetic. This has been confirmed by segregation results obtained by SAILER (1955), which correspond to a single autosomal recessive gene.

The occurrence of melanotic skin tumours was first studied by NORDBY (1933), who came to the conclusion that the defect is inherited, but with an unclear mode of inheritance. This has later been confirmed by Hook et al. (1979) who were able to increase the frequency of the defect by selection in a line of miniature pigs. Their data suggest that the hereditary basis is polygenic and similar to that reported in humans.

A hereditary basis of the transient skin disease known as pityriasis rosea has for the first time been suggested by WELLMANN (1953), who was able to exclude infectious agents as possible causes. The disease begins with the apparition of a few hyperhaemic patches on the underside of the animal. These rapidly spread in a circular fashion and then join together to form large circular marks similar to those found in ringworm. The disease appears in the first weeks of life and generally lasts until 3-4 months of age. Observations made in several countries (Heuner, 1957 ; Flatla et al., 1958 ; LARSSON, 1961 ; CORCORAN, 1964) show that the condition is widespread, of a hereditary origin and may go unnoticed by the breeder, as general health is not impaired. Its mode of inheritance is complex according to Wellman (1953) and Flatla et al. (1958), whereas LARSSON (1961), from his observations in Sweden, assumes a monogenic autosomal recessive inheritance.

Skin lesions of a different origin may also appear in the first or second week of life. This disease, known as dermatosis vegetans, differs from the preceding one in that it also affects the feet and the lungs. The pig usually die within four to six weeks from either pneumonia or secundary bacterial infections. FlatLA et al. (1961) showed dermatosis vegetans to be a semi-lethal hereditary disease due to a single autosomal recessive gene, a hypothesis which also fits the observations of Done et al. (1967). The disease has also been reported in Austria by Glawischnig et al. (1974) who tried unsuccessfully to obtain affected animals from matings between parents known to have given defective progeny. This genetic defect seems to affect mesodermal tissue selectively (dermis, intestinal, lymphoid tissue, tonsils and pulmonary lymph nodes) as shown by the histological observations of JERICHO (1974). The club-foot syndrome, reported by LARSSON (1953) and shown to be inherited as a single autosomal recessive gene, is likely to be the disease later described as dermatosis vegetans.

Abnormal mammae, called «inverted " or «cratered " teats, were first investigated by NordBy (1934 a), who suggested a simple recessive mode of inheritance. A recessive inheritance was also assumed by FISCHER (1957), HAMORI (1962 a) and PARIZEK et al. (1965), but more recent studies by Holmevist (1971), Molénat \& Thibault (1977), VENEV (1977) and CLAYTON et al. (1981) are in favour of a polygenic inheritance, with heritability estimates ranging from 0.10 to 0.76 . 


\section{Skeleton}

\section{A. Axial skeleton}

A shortened vertebral column, due to the absence of four cervical and two dorsal vertebrae and to the fusion of the remaining ones, has been described by GLuHovsCHI et al. (1967), in a Large White herd. As the parents are normal and no karyotype abnormality exists, the authors conclude that the defect is due to a single autosomal recessive gene.

The "kinky tail " condition characterized by rigid angles due to irregular vertebral fusions, which is one of the various tail anomalies of genetic origin found in mice, has also been shown to be hereditary in pig by NORDBY (1934 b), who assumed a single recessive gene as the main cause of the defect. A similar tail defect, sometimes associated with uro-genital disorders, has been reported by DonALD (1949) and RYLEY et al. (1955). DonalD assumes an incompletely dominant gene, with variable expressivity due to recessive modifying factors. For RyLEY et al., the genetic basis is likely to be complex and a threshold may be involved. No conclusion as to the inheritance of « kinky tail " could be reached by RICHTER \& SCHARRER (1959), whereas Fischer (1960) postulated a single dominant gene with low penetrance.

Rudimentary tail has been observed in connection with hydrocephalus, due to a recessive lethal gene (see below), and a tailless condition of hereditary origin associated with vertebral abnormalities has been reported by BROOKSBANK (1958).

\section{B. Head and appendages}

A common skull defect in pigs is brain hernia, which is due to a cleft in the skull, through which meninges may protrude (meningocele) or meninges and brain tissue (encephalocele). The early work reviewed by $\mathrm{KoCH}$ et al. (1957) points towards a sublethal recessive gene, with variable penetrance and expressivity according to CoHrs et al. (1963). GiLman (1956) suggests that a maternal dietary influence may affect the penetrance of the gene. Later results by MEYer \& Trautwein (1966), STEWART et al. (1972) and WiJERATNE et al. (1974) confirm that no simple genetic explanation exists for this defect.

Hydrocephalus is an enlarged head condition which results from an excess of cerebrospinal fluid either in the brain ventricles (internal hydrocephalus) or in the cranial cavities (external hydrocephalus). The defect is variable in expression and has been found associated with rudimentary tail and sometimes light-coloured hair and skin, in the Duroc breed, by BlunN \& Hughes (1938) and W ARWICK et al. (1943), who showed it to be due to a single autosomal recessive gene. Observations by Smith \& Stevenson (1973), on sire $x$ daughter matings within a Yorkshire $\times$ Landrace herd, confirm the single recessive hypothesis.

According to the review by Косн et al. (1957), the exact mode of inheritance for cleft lip, jaw and palate (cheilognathopalatoschisis) is uncertain. A simple recessive gene has been suggested by NORODD (1958) and a recessive gene with incomplete penetrance by LABIK (1972). Non-genetic factors may also be involved as shown by the breeding experiment of BUTZ \& MEYER (1960). 
In Swedish Large White, a condition characterized by shortened lower jaw (brachygnathia inferior) together with hind leg malformations has been observed by IDVALL (1952), who assumes a simple recessive mode of inheritance.

Complete absence of the lower jaw (agnathia) has been reported by KELLER (1941), Holz \& ForTuin (1956) and KRÜGER (1965), but the inheritance of this lethal condition has not been investigated.

Investigations on other jaw malformations (crooked or shortened jaw) with an uncertain hereditary basis have been reviewed by Косн et al. (1957). DoNE (1977) suggests that many facial deformities, including those due to atrophic rhinitis, have a genetically multifactorial aetiology.

A lethal factor, supposed to be recessive, is held responsible for the occurrence of bilobed ears, an abnormality which is sometimes accompanied by cleft palate and hind leg malformations (ANNETT, 1938).

Reduction in size of the ears has been reported to occur either alone or in connection with skull defects (NoRDBY, 1930). The condition is considered to be hereditary, but external causes may also produce it (HORNEFF, 1967).

The presence of tassels or «bells » in the neck region of the pig has been reported in several breeds (see $\mathrm{KOCH}$ et al., 1957). From the genetic investigations of KRONACHER (1924) and RoBerts \& Morrill (1944) it can safely be concluded that a single autosomal dominant gene is responsible for the development of those appendages.

\section{Limbs}

Absence of one, two or four legs has been reported in pigs. The absence of the four legs (legless) is a lethal condition, which has been described by JoHNSON \& Lush (1939) and shown to be due to a single autosomal recessive gene. The absence of one or two legs has several times been described in grown pigs. From the work reviewed by Косн et al. (1957) it can safely be concluded that the three-legged condition is due to a single autosomal recessive gene, whereas the less common two-legged condition (apodia) is genetically unclear.

The absence of toes (adactylia) has also been described in pigs, either alone or associated with several other abnormalities (Butz \& SCHnelle, 1951; BeER, 1962). A hereditary basis is probable but has not yet been clearly established.

Syndactyly and polydactyly have been extensively studied. The early genetic hypothesis of a single dominant gene responsible for syndactyly (Simpson's, 1908) has been later on confirmed by other workers with few exceptions (see Косн et al., 1957). The inheritance of polydactyly is much less clear, owing to the irregular expression of the defect, and so far no clear conclusion can be reached, according to КоCH et al. (1957). However, MALYNICZ (1982) has recently described a case of autosomal dominant complete polydactyly in Papua New Guinea village pigs. Homozygous piglets are lethal monsters with club foot and otocephaly.

A hereditary defect leading to unequal toes has been described by NordBY (1939). Its exact hereditary basis however remains to be explained.

A short-leg syndrome has been shown to be inherited as a single recessive gene by Swiger (1981). 


\section{Multiple abnormalities}

Various skeletal anomalies may occur on the same animal. Such is the case of the Pulawska lethal factor described by DABCZEwSKI (1949) and inherited as a single autosomal recessive gene. Various malformations affect the cranium bones, the vertebral column (vertebral fusion) and the ribs, and several internal organs (liver, pancreas, kidney and intestine are larger than normal, and lungs are rudimentary).

Other cases of multiple anomalies (involving skeleton and ears) have been reported by Ryley et al. (1955), Beer (1962) and' Trolldenier (1964). Their hereditary basis remains unclear, but they remind of the case, already mentioned, of ANNETT (1938).

As previously mentioned, rudimentary tail has been shown to be associated with

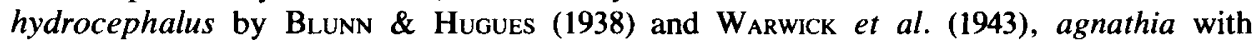
several malformations by KELLER (1941) and HoLz \& ForTUIN (1956), and polydactyly with club foot and otocephaly by MALYNICZ (1982).

In many cases the genetic study of skeletal anomalies is made difficult becausc some of them arise as a result of metabolic disturbances of non-genetic origin occurring during embryonic development, as indicated in particular by FREDEEN \& JARMOLUK (1963). These authors give several examples of skeletal defects not reported previously and for which no genetic explanation can be offered. This is also the case for a vertebral column malformation (lordo-scoliosis) reported by CELA \& COLOMBANI (1972).

Lameness (or the so-called leg weakness syndrome) occurs frequently in the modern pig. Various forms of skeletal lesions (osteochondrosis, epiphysiolysis, arthritis) are usually at the origin of this defect. An extensive literature is devoted to the subject, and many authors have suggested that the disease is partly of hereditary origin. A moderate heritability is usually found for leg weakness, when it is assessed either visually (Smith, 1966 ; Gröndalen, 1974 ; Bring-Larsson \& Sundgren, 1977 ; Bereskin, 1979 ; Webb \& Russell, 1981) or radiologically (Nagel \& Seifert, 1980).

\section{Eye}

Lack of pigmentation of the iris leads to the "glass-eye " defect also called heterochromia iridis. An account on the heredity of this condition has been given by Gelati et al. (1973). In the first genetic work, DüRR (1937) concluded to an incompletely dominant gene, as only about 50 percent of the heterozygous individuals exhibit the trait. Gelatl et al. (1973) conclude that, in their herd of miniature pigs, the defect is due to an autosomal recessive gene (het), whose expression is variable and in particular is influenced by the white colour gene $(I)$. The two hypotheses can be reconciled if one assumes, as suggested by GELATI et al. (1973), that pigs with bilateral heterochromia are homozygous at the Het locus and unilateral or partial heterochromia, very frequent in DÜR's data, may appear in heterozygous individuals. The gene may thus be considered as truly recessive for bilateral heterochromia.

Congenital blindness is of frequent occurrence in pigs and generally the result of various degrees of microphtalmia. Non-genetic causes may be implied in eye defects, especially lack of vitamin A. Several workers however have shown that a genetic basis exists for blindness in pigs. The various cases studied have been reviewed by $\mathrm{Koch}$ et al. (1957) who observe that their own investigations, on the progeny of a blind boar, do not always confirm previous ones and conclude that further research is needed in order to clarify the heredity of the condition. 
Cyclopia is an abnormality found in several species and shown to be hereditary in guinea pig and rabbit. In the pig, cyclopia often goes along with several other abnormalities and its heredity remains to be clarified (Косн et al., 1957).

The red-eye mutation (also known as albinismus oculi) has been referred to in the section on coat colour.

\section{Neurological and neuromuscular disorders}

Congenital tremor (or myoclonia) is a frequent disease affecting the central nervous system of pigs, and it may have several different causes. In the taxonomy proposed by DONE (1976 a), those forms of tremor in which morphological lesions are found are called type A. Two of these are of genetic origin, namely AIII, which is due to a sex-linked recessive gene (HARDING et al., 1973) and AIV, which is due to an autosomal recessive gene (PATtERSON et al., 1973). Type AIII is similar to the "jimpy " mutant in mice and type AIV to the murine leukodystrophy designated « quaking " (DonE, $1976 \mathrm{~b}$ ). Neurochemical techniques allow distinguishing the hereditary types from those due to transplacental infections (Patterson \& Done, 1977). There are also several observations indicating a possible role of the boar in a non-genetic transmission of myoclonia (STromberG, 1975). A favourable association in fattening pigs between tremor and growth and carcass quality has been shown by Gedde-DAHL \& Standal (1970), in contrast with the unfavourable effects of the disease in early life.

Epilepsy has been investigated by SonNENBRODT (1944), who considered it unlikely to be monogenic and postulated two or more factors responsible for the disease.

A congenital motor defect, demonstrated by clinical signs of ataxia and perverse movements, with no morphological defect in the central nervous system at birth, but dysplasia of the cerebellar cortex in older pigs, is inherited as a single autosomal recessive trait in Large White and Wessex Saddleback pigs (DONE, 1978). This has recently been confirmed in Yorkshire pigs in Finland (Rimaila-Pärnänen, 1982).

Several cases of hind leg paralysis have been reported in Norway, in the U.S.S.R. and in Germany. Косн et al. (1957) consider those cases as possibly all due to the same recessive lethal gene. The case reported by LuDvigsen et al. (1963) in the Danish Landrace may be due to a different recessive gene, this condition being associated with abnormal lumbar vertebrae.

In 1933, HallqVist described an abnormality of the forelegs in Swedish Landrace which he called bent-stiff-legged and showed to be due to an autosomal recessive gene. This defect, known as arthrogryposis in several other domestic species, may affect the four limbs as in the cases reported by ELY \& LeIPOLD (1979) and also shown to be due to a single autosomal recessive gene. Swatland (1974) considers the general name congenital articular rigidity (CAR) as more appropriate, and in his review on porcine CAR he classifies the observed cases into hereditary, as the previously mentioned ones by HALLQVIST (1933), and environmentally-induced or sporadic due to an unknown cause. As to the primary cause of rigidity, it may be muscular, nervous (neuroaxonal dystrophy in ELY \& LEIPOLD's cases) or skeletal as in the thickleg syndrome where both connective tissue and bone developments are abnormal. This defect, which preferentially affects the forelegs, is inherited as an autosomal recessive gene. It is not certain that this gene is different from the one responsible for bent-stiff-leg. 
Splayleg is a condition of newborn piglets in which the hind legs and sometimes the forelegs tend to splay sidewards and forwards as a result of muscular weakness. In their reviews of the subject SWATLAND (1974) and WARD (1978) conclude that splayleg has a genetic basis, probably polygenic, though sometimes it occurs only in males and may be due to a sex-linked gene with variable penetrance (LAx, 1971) Myofibrillar hypoplasia has sometimes been observed in splayleg (though it may also be found in normal pigs) and indicates a retardation in the development of the leg muscles as a consequence of a possibly general neuromuscular dysmaturity. Splayleg accompanied by tremor has been reported to occur in Hungary by Bertha (1975). Sellier $\&$ Ollivier (1982) show the genetic basis of the character to be of an additive polygenic type, with an estimated heritability of 0.47 . They also find a higher frequency of the defect in males (the character is sex-influenced but not sex-linked) and a higher incidence in larger litters.

Other disturbances in muscle development may result in the so-called asymmetric hindquarter syndrome (AHQS). A variety of degenerative and dystrophic changes have been seen in the muscles of AHQS pigs. The precise cause of the syndrome is still unresolved further than the observation of familial occurrence, which suggests a genetic liability (Done et al., 1975). This however could not be confirmed in a breeding experiment at the Hannover Veterinary School (Institut für Tierzucht, 1975).

A genetic basis is also assumed for the condition known as acute back muscle necrosis by BICKHARDT et al. (1975), according to whom this myopathy is one among several possible manifestations, induced by bodily exertion or stress, of a latent condition due to an insufficient muscle energy metabolism, other possible manifestations being the post mortem pale soft exudative (PSE) meat or the stress-induced sudden death or porcine stress syndrome (PSS). BradLEY et al. (1979) also found the defect associated with PSS.

PSE and sudden death are also connected with a genetic defect known as malignant hyperthermia (MH), a syndrome found in several other species including Man and which is triggered by halothane anesthesia. A rapid rise in body temperature, muscular rigidity and blotchy cyanosis of the skin are the most obvious symptoms. Death normally ensues if anesthesia is continued. A genetic basis was first suggested by $H_{\text {ALL }}$ et al. (1966). Christian (1972) assumed a single autosomal recessive gene with incomplete penetrance, and this has been later on subtantiated by the experimental results of Ollivier et al. (1975), SMith \& Bampton (1977), Andresen \& JENSEN (1977), Schwörer \& Blum (1977), Mc Phee et al. (1979), Hradecký et al. (1980) and Mabry et al. (1981). However, Minkema et al. (1977), in the Dutch Landrace, consider the gene to be fully penetrant. Possible breed differences in gene penetrance (along with important differences in gene frequency) have been suggested by OLLIVIER et al. (1978). Hypotheses involving more than one gene have been postulated by BRITT et al. (1978) and Williams et al. (1978). The relationships between malignant hyperthermia, PSE meat condition, porcine stress syndrome and various forms of myopathy, such as the "creeper " trait in Piétrain described by WELLS et al. (1980), need further clarification. Well established connections however exist, according to several investigators, between MH, liability to sudden death and muscular hypertrophy. In fact, the major gene responsible for muscular hypertrophy in the Piétrain pig may well be the MH gene itself - $\mathrm{Hal}^{s}$ (or $\mathrm{Hal}^{n}$ ) as opposed to the normal allele $\mathrm{Hal}^{+}$(or $\mathrm{Hal}^{\mathrm{N}}$ ) - as suggested by Ollivier (1980). 
A muscle disease, known in human as myositis ossificans, has been shown to occur on 34 out of 115 progeny of a boar who himself developed the condition at the age of 9 months (SEibold \& Davis, 1967).

More detailed information and references pertaining to this section may be found in general reviews on nervous or muscular disorders by Done (1968, $1976 \mathrm{~b})$, Swatland (1974) and Bradley \& Wells (1978).

\section{Haematological disorders}

Abnormal haemoglobin synthesis in the bone marrow is thought to be at the origin of congenital porphyria (found in human, cattle and pigs) in which excessive amounts of porphyrin are deposited in the bones and teeth and excreted in the urine and faeces. In pigs, the condition has been studied in detail by JøRGENSEN (1959) who considers it to be hereditary and due to one or more dominant genes, contrary to cattle where it depends on a recessive gene. However, Yamashita et al. (1980) suggest that porphyria in pigs is also due to a single recessive gene.

A hemophilia-like disease was reported and studied genetically by BogarT \& Muhrer (1942) in an inbred line of Poland-China swine and more recently by FAss et al. (1979). The disease was shown to be due to a single autosomal recessive gene. It is analogous to the human von Willebrand's disease, a type of hemophilia due to the lack of a plasma antihemophilic factor (factor VIII). Normal porcine plasma also contains a platelet aggregating factor (factor W) for human platelets and, as this W factor is associated with factor VIII, a quantitative assay of $\mathrm{W}$ makes it possible to detect heterozygous carriers of the hemophilia gene (GrIGGS et al., 1974).

A hereditary lymphosarcoma (leukemia) has been described in a herd of Large White pigs, and shown to be due to an autosomal recessive gene (Mc TAGGART et al., 1979).

Anemia may be genetically determined in piglets, as various blood parameters have been shown by several authors to be under genetic control, likely polygenic in nature (see GABRIS, 1973, for references).

The hemolytic disease of the newborn piglets is similar to icterus neonatorum in humans. Szent-Ivanyı \& Szabo (1953) assume an antigen, which they call Su, due to a dominant gene similar to the Rhesus factor in man, responsible for this sow-piglet incompatibility, which, owing to the particular pig placentation, can only express itself when the piglet has absorbed the antibodies present in the colostrum. The disease can also be produced experimentally, as shown by ANDRESEN \& BAKER (1963), who used an antigen of the B blood group system. Himeno et al. (1969) were able to identify one red cell antigen responsible for the disease and confirmed that it was due to a single gene. Antibodies against erythrocytes may also arise from the vaccination of the sow by the hog cholera crystal violet vaccine and several blood cell antigens may be involved (DUNNE, 1975).

A similar disease, thrombocytopenia, may arise from the development of maternal antibodies against the platelets of the piglets, with pathological changes characterized by paleness of various tissues and scattered hemorrhages in various parts of the body (Stormorken et al., 1963). The simultaneous occurrence of hemolytic disease and thrombocytopenia has been reported (see DunNE, 1975). 


\section{Endocrine and metabolic defects}

Only three cases of dwarfism in the pig have been mentioned in the literature according to Petrov (1974), who himself obtained a female dwarf in the $F_{2}$ of a black Mangalitza $\times$ East Balkan cross. A subsequent full-sib mating between normal parents gave $8 \mathrm{~F}_{3}$ piglets of which 2 were dwarfs. The author considers the anomaly as similar to achondroplasy in cattle and similarly inherited as a recessive.

Investigations on the disease of newborn pigs called oedema, myxoedema or hydrops, have been reviewed by $\mathrm{KoCH}$ et al. (1957). Their conclusion is that a thyroid deficiency is at the origin of the disease, which appears to be inherited as a single autosomal recessive gene. In the pig oedema appears to be quite distinct from hemolytic disease, whereas in human and rabbit hydrops has been assumed to be a consequence of mother-fetus incompatibility due to a Rhesus-like factor.

A new syndrome, characterized by acute respiratory distress and by abnormalities of the skin, hair and thyroid, has been described in piglets by Gibson et al. (1976). The syndrome, similar to the respiratory distress syndrome of the new born infant and the "barker" syndrome of the foal, is inherited as a single autosomal recessive

gene. Wrathall et al. (1977) suggest that the manifestations of the syndrome may all be more or less directly related to a fetal hypothyroidism.

A disturbance of calcium metabolism, causing severe rickets in pigs after the age of five weeks, has been shown to be due to an autosomal recessive gene by MEYER \& Plonait (1968) and confirmed by HaRmeyer (1982). In piglets with inherited rickets, the rachitic lesions do not respond to dietary vitamin $\mathrm{D}$ and the $\mathrm{Ca}$ intestinal resorption is markedly reduced, as in the vitamin D-resistant form of the disease in children. HARMEYER (1982) offers some evidence that this hereditary defect may also in pigs be due to an insufficient renal production of the vitamin $D_{3}$ hormone.

Obesity has been reported to occur in piglets and to be a semi-lethal condition with an unclear genetic aetiology (KосH et al., 1957). Recently, an obese syndrome has been described in a native breed of Georgia by MARTIN et al. (1973), and shown to be comparable to human diabetes. In fact, the pig has a natural propensity to excess adiposity and fat tissue development is a complex polygenic character which has been intensely selected by the breeder (see performance traits). A review on genetic and metabolic aspects of swine adipose tissue development has been given by HENRY (1977). Variations in glucose tolerance have been shown to exist in pigs and some attempts are being made at producing a genetically diabetic pig for biomedical purposes, by exploiting presumably polygenic variations in the rate of glucose utilization (PHILLIPS et al., 1979).

\section{Internal organs}

\section{A. Digestive tract}

Atresia ani (closure of the anal outlet) is one of the most frequent abnormalities encountered in pigs : 0.14 p. 100 in Germany according to Triebler et al. (1974), 0.14 and 0.31 p. 100 respectively for British Large White and Landrace from REED's survey (1976). Various genetic hypotheses have been proposed : see КoCH et al. 
(1957) and WIESNER \& WILlER (1974) for reviews. Either one recessive gene with incomplete penetrance or two incompletely dominant genes have been proposed as the most likely genetic explanations. NeEteson (1964), from observations on 36 litters, ruled out six different genetic explanations and retained as a provisional conclusion a two dominant genes hypothesis. The frequency of the defect in affected litters observed by Triebler et al. (1974) agrees with the hypothesis of a recessive gene with $50 \mathrm{p}$. 100 penetrance. The linkage mentioned between atresia ani and thickleg by WALTHER et al. (1932) awaits further confirmation.

A different abnormality with similar consequences, aplasia of the anal sphincter, has been reported by HAMÓRI (1965) who considers it as a semilethal hereditary defect whose transmission still remains to be clarified.

Scrotal (or inguinal) hernia, a protrusion of the intestine into the scrotum (or through the inguinal canal), is probably the most frequent hereditary abnormality in the pig. In an externe case, 5 p. 100 of the male pigs were affected (MAGEE, 1951). Scrotal hernia is a sex-limited defect, whereas inguinal hernia is found in both sexes. Inguinal hernia in females has been reported to occur in conjunction with abnormal ovaries (Colennrander \& Wensing, 1975). According to Warwick (1926), scrotal hernia is dependent on two recessive genes, whereas BERGE (1941) considers it to be monofactorial with incomplete dominance and HAMORI (1962 b) suggests two sex-linked recessive genes. After reanalyzing published data, Sitrman (1973 a) came to the conclusion that scrotal (inguinal) hernia is fully penetrant in males homozygous recessive at two loci. These are normally viable but homozygous recessive females have a lowered viability, which may produce a deficiency of sisters of affected males. However, MAGEE (1951) assumes the character to be polygenic (with a threshold) with low heritability, and under the same assumption a high heritability has been estimated by MIKAMI \& FREDEEN (1979).

Umbilical hernia is a less frequent type of hernia ; its frequency is higher in females than in males. Косн et al. (1957) mention studies showing the condition to be hereditary, possibly of a dominant type.

A «baby pig disease », appearing as a degeneration of the myenteric stomach plexus, has been reported to occur in the progeny of two boars in a Danish experimental farm by STEINICKE \& NieLSEN (1959) who suggest that hereditary as well as exogenous factors are probably involved.

A condition called diverticulosis has been observed with a high frequency in an experimental herd in New-Zealand by HANCOCK (1950). The abnormality appears as a series of pockets formed by the intestinal mucous membrane and it is associated with a thickening of the gut. The mode of inheritance is not clear but a recessive gene may be implied.

\section{B. Uro-genital system}

A bilateral renal hypoplasia has been observed in the progeny of one Large White boar by CORDES \& DODD (1965) who state a strong evidence that the defect is due to a single autosomal recessive gene.

An obstruction of the ureters, which occurs shortly after birth and leads to death by uremia within a few days, is at the origin of the baby pig disease described by LUKAS (1953) and considered by him as hereditary. 
Recently, the existence of an autosomal dominant gene responsible for renal cysts has been shown by WiJERATNE \& WELLS (1980).

Various uro-genital disorders have previously been mentioned in connection with a hereditary tail defect (DONALD, 1949 ; RYLEY et al., 1955).

The most common abnormality in the male reproductive system is cryptorchidism, for which a recent and very detailed review by Sitman \& Woodhouse (1977) is available. By reanalyzing five sets of published data, they come to the conclusion that those data agree with the hypothesis of completely penetrant recessive genes at two autosomal loci, except in the Lacombe breed where a multifactorial threshold model is more plausible. With this same model, MiKami \& FredeEN (1979) obtain a heritability of 0.5 for the underlying variable. TRIEBLER et al. (1974), from observations in German Democratic Republic, assume one autosomal recessive gene.

Boar sterility may be due to either incapacity to copulate (sexual impotence) or incapacity to fertilize. Among 22 sons of a slow breeding boar, Holst (1949) found 12 that had to be discarded as sexually impotent and were the sons of 6 different sows. His data suggest, as those of Aamdal \& Nes (1958) and WierzbowsKi (1959), a hereditary basis for sexual impotence but they do not corroborate the hypothesis suggested by FunKQuisT (1929), on a rather limited sample, of a recessive sex-linked mode of inheritance.

Incapacity to fertilize may be due to testicular hypoplasia for which a hereditary basis has been suggested by Holst (1949), WOHLFARTH (1964) and WOHLFarTH \& Seffner (1968). A case due to an abnormal sex chromosome constitution (XXY)

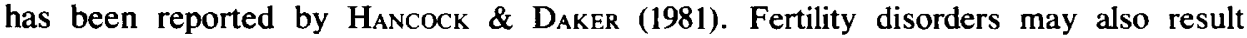
from epididymal aplasia which has been found by KöNIG et al. (1972) in a fertile boar (with unilateral aplasia) and three of his sons. These observations are in favour of a recessive mode of inheritance, as for a similar and much more frequent defect in bulls.

Abnormal spermiogenis may also affect fertility. The knobbed acrosome defect, due to an autosomal recessive gene in cattle, is likely to have a different genetic basis in pig. BISHOP (1972) rightly remarks that the recessive mode of inheritance suggested by WoHLFarTH (1961) is not supported by his own data. A new defect of the sperm head, appearing as a nuclear cyst and associated with lowered fertility, has been described by BLOM (1973) who called it "SME-defect " from the name of the boar carrying it and it is considered as probably hereditary by ANDERSEN \& FilseTh (1976) and BLOM \& JENSEN (1977), the latter authors assuming a simple recessive mode of inheritance. It cannot yet be ascertained whether this sperm defect is related or not to the preceding one.

Finally, it must be mentioned that various chromosomal abnormalities may reduce boar fertility as a consequence of unbalanced gametes produced at meiosis which increase embryonic mortality (HenRICSON \& BACKSTRÖM, 1964 ; VoGT et al., 1974). Thus a reduction of about 50 p. 100 is generally observed in the size of the litters produced by a boar carrying a translocation, as it is the case for the reciprocal translocation found by Popescu \& Legault (1979). Ten different types of translocations have so far been reported in the pig, as reviewed by POPESCU (1982).

Among gross genital abnormalities observed in gilts by WIGGiNs et al. (1950), the most frequent are tubal abnormalities (1.4 p. 100), cystic follicles (1.7 p. 100) and missing parts $(0.7$ p. 100$)$, if one excludes intersexuality and immature genital tract. 
Such abnormalities, which explain about one quarter of the reproductive failures, have no established hereditary basis, except for a segmental aplasia of the uterus shown to be due to one autosomal recessive gene (KING \& LinARES, 1980).

Intersexuality is a frequently occurring defect in pigs, the reported frequencies ranging from 0.1 to 1.4 p. 100 (BАCKSTRÖM \& HeNRICSON, 1971). In general intersexes may be either true hermaphrodites, which have gonads of both sexes, or pseudohermaphrodites, these having either female or male gonads and being called accordingly female or male pseudohermaphrodites. The great majority of pig intersexes belong to the latter category and they have been shown to possess the normal female XX chromosome constitution, and may be regarded as masculinized females (BreEuwsma, 1970 ; BACKSTRÖM \& HenRICSON, 1971). Most authors consider this type of intersexuality as hereditary : see Koch et al. (1957), Breeuwsma (1970) and BiShop (1972) for reviews. The simplest hypothesis, proposed by several authors, of a recessive autosomal gene with sex-limited expression, is excluded by BACKSTRöm \& HENRICSON (1971) who imply several genetic causes on the grounds of a higher frequency of abnormalities among intersexes and also of a reduced sex-ratio due to an increased female embryonic mortality. Breeuwsma (1970) came to the conclusion that intersexuality is controlled both paternally (as shown by differences between boars with regard to its incidence among their offspring) and maternally (through an early contact between male and female blastocysts due to crowding of the uterus). However, when the same data were reanalyzed by Sittmann et al. (1980), maternal and other environmental factors appeared to be unimportant, and intersexuality was held to be essentially genetic, either with polygenic inheritance or more likely due to recessive genes at very few autosomal loci.

In some cases, as those reported by Glunovschi et al. (1969) and Lojda (1975), male pseudohermaphrodites show a male chromosomal constitution (XY). This condition, much rarer than the $\mathrm{XX}$ hermaphroditism, is comparable to the human syndrome of testicular feminization. Two possible genetic hypotheses have been proposed, in Man as well as in pig, either an autosomal dominant gene or a sex-linked recessive, between which it is not yet possible to decide (LojDA, 1975).

Freemartinism as another cause of intersexuality has been reported in pigs. Bosma et al. (1975) have reviewed such cases and their own ones, in which an $\mathrm{XX} / \mathrm{XY}$ mosaicism is found in lymphocytes and an $\mathrm{XX}$ pattern in kidney cells. This suggests that placental cross-circulation between embryos of different sexes is the primary cause of intersexuality, as in cattle free-martins.

Abnormal chromosome pattern of the Klinefelter type (XXY) and various mosaics have occasionally been reported in pig intersexes (see the review by HuLOT, 1969) and also in a boar with testicular hypoplasia (see above).

To summarize the above sections on genetic abnormalities, a list is given in table 4 of 29 defects which may be considered as probably monogenic.

\section{Disease resistance}

Resistance to disease is not in general simply inherited, apart from the purely genetic diseases which have been described before, like pneumonia in dermatosis vegetans, tremor, hemophilia, leukemia, hemolitic disease, oedema, respiratory distress, 
TABLE 4

A list of probably monogenic abnormalities in the pig.

Liste des anomaties porcines probablement monogéniques.

\begin{tabular}{|c|c|c|}
\hline Abnormality & Mode of inheritance & Degree of lethality \\
\hline $\begin{array}{l}\text { Hairlessness } \\
\text { Hairlessness } \\
\text { Woolly hair }\end{array}$ & $\begin{array}{l}\text { Autosomal recessive } \\
\text { Autosomal dominant } \\
\text { Autosomal dominant }\end{array}$ & Homozygous lethal \\
\hline $\begin{array}{l}\text { Epitheliogenesis imperfecta } \\
\text { Dermatosis vegetans }\end{array}$ & $\begin{array}{l}\text { Autosomal recessive } \\
\text { Autosomal recessive }\end{array}$ & $\begin{array}{l}\text { Semi-lethal }\left(C_{17}\right)\left(^{*}\right) \\
\text { Semi-lethal }\left(C_{13}\right)\end{array}$ \\
\hline $\begin{array}{l}\text { Hydrocephalus } \\
\text { Tassels } \\
\text { Legless } \\
\text { Three-legged } \\
\text { Syndactyly } \\
\text { Polydactyly } \\
\text { Pulawska factor }\end{array}$ & $\begin{array}{l}\text { Autosomal recessive } \\
\text { Autosomal dominant } \\
\text { Autosomal recessive } \\
\text { Autosomal recessive } \\
\text { Autosomal dominant } \\
\text { Autosomal dominant } \\
\text { Autosomal recessive }\end{array}$ & $\begin{array}{l}\text { Homozygous lethal } \\
\text { Lethal }\left(\mathrm{C}_{16}\right)\end{array}$ \\
\hline Heterochromia iridis & Autosomal recessive & \\
\hline $\begin{array}{l}\text { Congenital tremor A III } \\
\text { Congenital tremor A IV } \\
\text { Congenital ataxia }\end{array}$ & $\begin{array}{l}\text { Sex-linked recessive } \\
\text { Autosomal recessive } \\
\text { Autosomal recessive }\end{array}$ & $\begin{array}{l}\text { Semi-lethal } \\
\text { Semi-lethal } \\
\text { Semi-lethal }\end{array}$ \\
\hline $\begin{array}{l}\text { Hind leg paralysis } \\
\text { Bentleg } \\
\text { Thickleg } \\
\text { Malignant hyperthermia }\end{array}$ & $\begin{array}{l}\text { Autosomal recessive } \\
\text { Autosomal recessive } \\
\text { Autosomal recessive } \\
\text { Autosomal recessive }\end{array}$ & $\begin{array}{l}\text { Lethal }\left(C_{2}\right) \\
\text { Lethal }\left(C_{6}\right) \\
\text { Semi-lethal }\left(C_{5}\right)\end{array}$ \\
\hline $\begin{array}{l}\text { Hemophilia (von Willebrand's disease) } \\
\text { Leukemia } \\
\text { Hemolytic disease }\end{array}$ & $\begin{array}{l}\text { Autosomal recessive } \\
\text { Autosomal recessive } \\
\text { Autosomal dominant }\end{array}$ & $\begin{array}{l}\text { Semi-lethal }\left(C_{15}\right) \\
\text { Lethal }\left(C_{14}\right)\end{array}$ \\
\hline $\begin{array}{l}\text { OEdema } \\
\text { Acute respiratory distress ("barker") } \\
\text { Rickets }\end{array}$ & $\begin{array}{l}\text { Autosomal recessive } \\
\text { Autosomal recessive } \\
\text { Autosomal recessive }\end{array}$ & $\begin{array}{l}\text { Lethal }\left(\mathrm{C}_{12}\right) \\
\text { Lethal }\end{array}$ \\
\hline $\begin{array}{l}\text { Renal hypoplasia } \\
\text { Renal cysts } \\
\text { Uterus aplasia }\end{array}$ & $\begin{array}{l}\text { Autosomal recessive } \\
\text { Autosomal dominant } \\
\text { Autosomal recessive }\end{array}$ & Lethal \\
\hline
\end{tabular}

(*) Reference in the international list of lethal defects given by WIESNER and WIILE:R (1974).

rickets, etc. However, a resistance to neonatal diarrhoea due to a single autosomal recessive gene has been reported by RUTTER et al. (1975) and further investigated by GibBons et al. (1977). Resistance to leptospirosis has been shown to be associated with various genetic markers by PRzYtulski \& Porzeczkowska $(1976,1979)$, and lung lesions with adenosine deaminase by HYLDGAARD-JENSEN (1978).

More frequently, disease resistance behaves as a polygenic character with one (or several) threshold, and the concept of "liability " should in this context be preferred to " susceptibility", as liability includes all circumstances, internal as well as external, which can influence the manifestation of the threshold character (FALCONER, 1965; Done \& WiJeratne, 1972). Such a kind of genetic resistance has been shown to exist 
for several specific diseases, namely swine fever and foot-and-mouth disease (SMITH et al., 1938) brucellosis (CAMERON et al., 1943), pigling dysentery (ENGELHARDT, 1951), lactation failure (RINGARP, 1960 ; MARTIN \& MC Dowell, 1975), tuberculosis (GEdymiN et al., 1964), gastric ulcer (BERRUECOS \& RoBISON, 1972), atrophic rhinitis (e.g. Jonsson, 1965 ; Seifert et al., 1971 ; Planchenault et al., 1978 ; Kennedy \& Moxley, 1980), respiratory diseases (LUNDEHEIM, 1979) and leptospirosis (PrZYTULSKI \& Porzeczkowska, 1980). In their review of early selection experiments for resistance against swine fever, SмIтH et al. (1938) conclude that a certain degree of resistance is inherited, the most likely mode of inheritance being polygenic, with recessive factors. They also state that inbreeding reduces and crossbreeding enhances disease resistance, which confirms the existence of recessive factors. This has since been shown in numerous investigations (see the review by SELLIER, 1970) to be a rather general phenomenon.

\section{Immunology}

For a long time the research on pig immunogenetics has been confined to erythrocyte antigens or blood groups. The first steps in this field are the discovery of the A blood factor by SzymanowsKi et al. (1926) and the genetic study of KaEMPFFer (1932) hypothesizing that the A factor is inherited as a Mendelian dominant character. A detailed review of the earlier work on pig blood groups has been made by ANDRESEN (1962): at that time, 22 blood factors had been assigned to 10 genetic systems (A, B, E, F, G, H, I, J, K, L). Since then, more than 40 other blood group factors belonging to 8 of these 10 systems or to 5 new systems $(C, D, M, N$, O) have been genetically described, as successively summarized by DinkLAGE (1970 a), Larsen (1971), Imlah (1972 a), Rasmusen (1975 a), Agergaard \& Nielsen (1978), Gahne (1979), Oishi (1979) and Hruban (1981).

The current status of the 15 blood group systems controlling the polymorphism of pig erythrocyte antigens is given in table 5, with a list of references for each of them. A large number of reports being devoted to the most polymorphic systems (E, $\mathrm{H}, \mathrm{K}, \mathrm{L}$ and $\mathrm{M}$ ), one or two recent references where these reports are quoted are only given in addition to the original report. From 2 to 16 "alleles " or "phenogroups" are presently known in each system. The dash superscript "-" in a gene symbol refers to a "silent» allele for which no antigenic substance is yet detected and the corresponding systems, i.e. $\mathrm{C}, \mathrm{H}, \mathrm{J}, \mathrm{K}$ and $\mathrm{M}$, are called "open ». In contrast, the 2-allele B, D, G, I, and $\mathrm{O}$, the 3-allele $\mathrm{F}$ and $\mathrm{N}$, the 6-allele $\mathrm{L}$ and the 15 -allele $\mathrm{E}$ systems are "closed"systems. The existence of recombinations within the complex E system has been postulated by RASMUSEN (1963) and BAKER (1971).

The two-factor A system has serological and genetic properties which give it a special position. Two types of A-positive red blood cells, i.e. A(Ac) and Aw(Ap), are recognized (Hojný \& Hála, 1965 a ; HojnÝ \& Stratil, 1978). Moreover, while genes are codominant for the other blood group systems, the gene $A^{A}$ controlling the factor $\mathrm{A}$ is completely dominant on its allele $a^{O}$ controlling the factor $\mathrm{O}$. The existence of A-O negative individuals and the occurrence of A-positive offspring with allegedly A-negative parents have led several authors to the hypothesis that the expression of the $A$ and $O$ antigens is influenced by genes at a different locus (ANDRESEN, 1962 ; SAISON \& InGRAM, 1962 ; RASMUSEN, 1964 ; HojnÝ \& Hála, 1965 a). The results of 


\section{TABLE 5}

The current status of the blood group systems in the pig.

Etat actuel des systèmes de groupe sanguin du Porc.

\begin{tabular}{|c|c|c|c|c|}
\hline System & $\begin{array}{l}\text { Number } \\
\text { and designation } \\
\text { of blood factors }\end{array}$ & $\begin{array}{l}\text { Minimum } \\
\text { number of } \\
\text { "alleles" }\end{array}$ & Allelic symbols & References \\
\hline A & $2 \mathrm{~A}(\mathrm{Ac}, \mathrm{Ap}), \mathrm{O}$ & 2 & $A^{A}, a^{O}$ & $\begin{array}{l}\text { HOJNÝ and HÁlA (1965a), } \\
\text { HOJNÝ and STRATIL (1978) }\end{array}$ \\
\hline B & $2 \mathrm{Ba}, \mathrm{Bb}$ & 2 & $B^{a}, B^{b}$ & BAKER and ANDRESEN $(1962,1964)$ \\
\hline $\mathrm{C}$ & $1 \mathrm{Ca}$ & 2 & $C^{a}, C^{-}$ & ANDRESEN and BAKER (1964) \\
\hline D & $2 \mathrm{Da}, \mathrm{Db}$ & 2 & $D^{a}, D^{b}$ & $\begin{array}{l}\text { SAISON et al. (1967), } \\
\text { HRADECKÝ and LINHART (1970) }\end{array}$ \\
\hline $\mathrm{E}$ & $\begin{array}{l}16 \mathrm{Ea}, \mathrm{Eb}, \mathrm{Ed}, \mathrm{Ee}, \mathrm{Ef}, \\
\mathrm{Eg}, \mathrm{Eh}, \mathrm{Ei}, \mathrm{Ej}, \mathrm{Ek}, \\
\mathrm{El}, \mathrm{Em}, \mathrm{En}, \mathrm{Eo}, \mathrm{Ep}, \\
\mathrm{Er}\end{array}$ & 15 & $\begin{array}{l}E^{I}=E^{\text {bdgkmp }}, \ldots \\
E^{I S}=E^{\text {abgmnop }}\end{array}$ & $\begin{array}{l}\text { ANDRESEN (1962) and many } \\
\text { subsequent reports quoted by } \\
\text { LINHART and ROMANOV (1975) }\end{array}$ \\
\hline $\mathrm{F}$ & $4 \mathrm{Fa}, \mathrm{Fb}, \mathrm{Fc}, \mathrm{Fd}$ & 3 & $F^{a c}, F^{b c}, F^{b d}$ & $\begin{array}{l}\text { ANDRESEN (1957), } \\
\text { HRADECKY and HOINÝ (1970), } \\
\text { VORON and SOKOLENKO (1971) }\end{array}$ \\
\hline $\mathrm{G}\left({ }^{*}\right)$ & $2 \mathrm{Ga}, \mathrm{Gb}$ & 2 & $G^{a}, G^{b}$ & ANDRESEN and WROBLEWSKI (1961) \\
\hline $\mathrm{H}$ & $5 \mathrm{Ha}, \mathrm{Hb}, \mathrm{Hc}, \mathrm{Hd}, \mathrm{He}$ & 7 & $\begin{array}{l}H^{a}, H^{b}, H^{a b}, H^{c d} \\
H^{b d}, H^{b e}, H^{-}\end{array}$ & $\begin{array}{l}\text { ANDRESEN and WROBLEWSKI (1961) } \\
\text { and subsequent reports quoted } \\
\text { by HOJNÝ (1973) }\end{array}$ \\
\hline I & $2 \mathrm{Ia}, \mathrm{Ib}$ & 2 & $I^{a}, I^{b}$ & ANDRESEN $(1962,1964)$ \\
\hline $\mathbf{J}$ & $2 \mathrm{Ja}, \mathrm{Jb}$ & 3 & $J^{a}, J^{b}, J^{-}$ & $\begin{array}{l}\text { ANDRESEN (1962), } \\
\text { HOJNÝ and HRADECKÝ (1972) }\end{array}$ \\
\hline K & $\begin{array}{l}7 \mathrm{Ka}, \mathrm{Kb}, \mathrm{Kc}, \mathrm{Kd}, \mathrm{Ke}, \\
\mathrm{Kf}, \mathrm{Kg}\end{array}$ & 6 & $\begin{array}{l}K^{a c e f}, K^{a c f}, K^{a d e}, \\
K^{a d e g}, K^{b f}, K^{-}\end{array}$ & $\begin{array}{l}\text { ANDRESEN and IRWIN (1959), BRUCKS } \\
(1966) \text {, HOJNÝ et al. (1979b), and other } \\
\text { reports quoted by NIELSEN and VöGELI } \\
(1982)\end{array}$ \\
\hline $\mathrm{L}$ & $\begin{array}{l}12 \mathrm{La}, \mathrm{Lb}, \mathrm{Lc}, \mathrm{Ld}, \mathrm{Lf}, \\
\mathrm{Lg}, \mathrm{Lh}, \mathrm{Li}, \mathrm{Lj}, \mathrm{Lk}, \\
\mathrm{Ll}, \mathrm{Lm}\end{array}$ & 6 & $\begin{array}{l}L^{a d h i}, L^{b c g i}, L^{b d f i}, \\
L^{a d h j k}, L^{a d h j l}, \\
L^{a g i m}\end{array}$ & $\begin{array}{l}\text { ANDRESEN (1962) and subsequent } \\
\text { reports quoted by HOJNÝ et al. } \\
\text { (1966) and LINHART (1971) }\end{array}$ \\
\hline M & $\begin{array}{l}11 \mathrm{Ma}, \mathrm{Mb}, \mathrm{Mc}, \mathrm{Md} \\
\mathrm{Me}, \mathrm{Mf}, \mathrm{Mg}, \mathrm{Mh} \\
\mathrm{Mi}, \mathrm{Mj}, \mathrm{Mk}\end{array}$ & 16 & $M^{a e}, M^{b}, \ldots, M^{-}$ & $\begin{array}{l}\text { NIELSEN (1961) and other papers } \\
\text { quoted by HoJNÝ et al. (1979a) }\end{array}$ \\
\hline $\mathbf{N}$ & $3 \mathrm{Na}, \mathrm{Nb}, \mathrm{Nc}$ & 3 & $N^{a}, N^{b}, N^{b c}$ & $\begin{array}{l}\text { HÁLA and HOJNÝ (1964), HOJNÝ et al. } \\
\text { (1966), SAISON (1967) }\end{array}$ \\
\hline $\mathrm{O}$ & $2 \mathrm{Oa}, \mathrm{Ob}$ & 2 & $O^{a}, O^{b}$ & $\begin{array}{l}\text { HOJNÝ and HÁL.A (1965b), } \\
\text { HOJNÝ et al. (1966) }\end{array}$ \\
\hline
\end{tabular}

(*) A factor (Gc) controlled by a $G^{\text {bc }}$ allele is likely to exist (ANONYmous, 1981). 
Rasmusen (1972) and Hojný (1974) indicated that alleles at the $\mathrm{H}$ blood group locus are involved in the determination of the A-O phenotypes. However, according to RASMUSEn et al. (1980), RASMUSEN (1981) and ANDRESEN (1981), there is evidence that inhibition of expression of $A$ and $O$ is not due to the $H$ system itself but to a distinct locus ( $\mathrm{S}$, as designated by RASMUSEN, 1964) closely linked to $\mathrm{H}$.

According to Hojný \& Stratil (1978), more genetical evidence is required to classify the so-called Hel system (SChmid \& Buschmann, 1966) as the 16th pig blood group system.

Immunogenetic studies in pigs have resulted in the detection of other markers than red blood cell antigens (GAHN, 1980).

The pig's major histocompatibility complex (MHC), which plays a decisive role in acute transplantation reactions, has been first evidenced by VAIMAN et al. $(1970,1971)$. This system, called SL-A (or SLA), presents many functional similarities with the murine H-2 and the human HLA systems (e.g. Vaiman, 1974 ; Ivanyi, 1977 ; LeVEZIEL, 1979). Its complex genetic organization and polymorphism are now under investigation : the SLA chromosomal region is composed of a yet unknown number of closely linked loci and its total size is likely to be less than 1 map unit. Serologically defined (SD) or class I antigens are controlled by genes of three allelic series at very closely linked loci (SLA-A, SLA-B and SLA-C), with more than 25 specificities (allelic forms) presently identified by the lymphocytotoxic test (e.g. Hruban et al., 1977 ; VaIman et al., 1979). The mixed lymphocyte reaction (MLR) is controlled by a region (SLA-D) which is distinct from but closely linked to that controlling the class I antigens (VAImAN et al., 1973 ; BradLey et al., 1974) : SLA-D is very likely to be localized outside the SLA-A, B, C region, as indicated by recombination studies of Vaiman et al. (1979) and Pennington et al. (1981 b). Class II (or Ia) antigens have also been found in the pig and are coded for by genes closely associated with those controlling the MLR (VAiman et al., 1975 ; LunNey \& SACHs, 1979 ; Chardon et al., 1981 ; Pennington et al., 1981 b). In addition, the SLA complex influences the level of serum hemolytic complement activity (VAIMAN et al., 1978 b) and SLA-like antigens have been demonstrated on boar spermatozoa (Vaiman et al., 1978 a). Current views on the genetic organization of the SLA chromosomal region (with the five loci A, B, C, D, and DR), the specificities so far recognized (more than 40) and the strong linkage disequilibria exhibited by the SLA genes have been summarized by RENARD et al. (1982).

Besides SLA antigens, genetically determined leucocyte antigens with different designations have also been described in early studies (e.g. Simon \& Hruban, 1971; SCHmid \& CWIK, 1972) and it is not known whether all or some of them belong to the SLA system. An alloantigen distinct from serologically determinable SLA antigens has been detected on lymphocytes by Hruban et al. (1978) and designated SLB : the SLB locus has been shown to be independent of the SLA complex of loci. Six different B-lymphocyte-specific antigens, provisionally designated Mü-SB 1, ..., Mü-SB 6, have been identified by CwIK et al. (1981): they follow an autosomal and codominant mode of inheritance and are independent of the SLA system. Moreover, the presence of red blood cell antigenic substances from the A, E, G and N systems has been demonstrated on leucocytes and other tissue cells : e.g. Hála (1967), Simon \& Hojný (1972), Simon \& Hruban (1972), and Hruban et al. (1972). The results of HRUBAN et al. (1974) indicate the survival of skin grafts to be apparently influenced 
by differences in the $\mathrm{E}$ blood group system and this highly polymorphic system might represent a minor histocompatibility system according to IVANYI (1977) and PAZDERA et al. (1981). Furthermore, Pennington et al. (1981 a) have presented evidence for one or two non-SLA-linked immune response gene(s) controlling the rejection of SLA-identical renal allografts.

The term allotype refers to genetic variants of soluble plasma proteins which can be detected by the application of immunological techniques. Several classes of allotypes are presently known in the pig. Two $\gamma$-globulin (immunoglobulin) allotypes, controlled by codominant alleles $\left(G l^{a}\right.$ and $\left.G l^{b}\right)$, have been first demonstrated by RASMUSEN (1965 a). In the study of NiELSEN (1972), four immunoglobulin allotypes (a, $\mathrm{b}, \mathrm{c}, \mathrm{d})$ have been found and they appear to be simply inherited and controlled by multiple genes at a single autosomal locus or at very closely linked loci. The genetic control of nine antigenic markers of immunoglobulins $\left(A_{1}, A_{2}, A_{3}, B_{1}, B_{2}, C_{1}, C_{2}\right.$, $D_{1}$ and $D_{2}$ allotypes) has been investigated by RAPACZ \& HASLER-RAPACZ (1982). Among the three allotypic antigens detected by Orshi et al. (1979 a), two belong to the $\beta$ globulin electrophoretic fraction and are controlled by alleles of the PSA-I locus, while the third one belongs to the $\alpha$-globulin fraction and is controlled by a gene of the PSA-II locus. Possible identities between these three allotypes and those previously reported by LANG (1970), TIKнonov et al. (1970) and DunieC (1972) are discussed by OISHI et al. (1979 a). However, the most extensively studied class of pig allotypes involves blood serum low density $\beta$-lipoproteins (LDL) which exhibit a marked antigenic polymorphism in this species. Most of LDL allotypic specificities are determined by a series of codominant alleles at an autosomal locus, designated $\mathrm{Lpb}$ (formerly $\mathrm{Lpp}$ ) : e.g. RAPACZ et al. (1970), RAPACZ (1974), RAPACZ et al. (1976), ANDRESEN et al. (1976), RAPACZ et al. (1978), and HoJNÝ \& DunIEC (1980). In addition to the Lpb system, four other serum lipoprotein systems (Lpr, Lps, Lpt and Lpu) have been identified by RAPACZ \& Hasler-RAPACZ (1980). The current status of the immunogenetic polymorphism controlled by these five systems is summarized by RAPACZ (1982).

No additive genetic variation for the immune responsiveness of pigs to sheep erythrocytes could be detected within breed by RADzikowski et al. (1974), though significant differences between breeds have been found in this study. In later studies, evidence for within-breed additive genetic variation has been presented with respect to the immune response of pigs to bovine or human serum albumin (HuANG, 1978; HyldgaARd-JENSEN, 1979) and to some $E$. coli antigens (Edfors-LiLja et al., 1982). In addition, MEYER et al. (1982) have successfully performed selection for increased antibody forming capacity to dinitrophenyl (DNP)-hapten in a pig line. Genes (Ir-Lys) located within or near to the SLA chromosomal region are involved in the humoral immune response against egg-white lysozyme according to VaIMAN et al. (1978 c).

\section{Biochemical polymorphism}

The majority of the polymorphic protein systems presently known in farm animals have been detected by means of starch gel electrophoresis as introduced by SMmriEs (1955). Electrophoretic variants of proteins have been first described in pig blood serum by Ashton $(1957,1960)$ and Kristjansson $(1960 \mathrm{a}, 1960 \mathrm{~b}, 1961)$ and thereafter our knowledge 
on the pig protein polymorphisms and their genetic control has regularly extended as it can be seen in the successive reviews of OGden (1961), Buschmann (1965 a), Lush (1966), Buschmann \& Schmid (1968), Bouw \& Osterlee (1969), Stormont (1970), Larsen (1971), Klucinski (1973), Mc Dermid et al. (1975), Widar et al. (1975), HyldgaARd-Jensen \& Jørgensen (1978), Oishi (1979) and Gahne (1979).

Most of the polymorphic loci involve blood proteins and a list of serum proteins and red cell enzymes found to be polymorphic in the pig is given in tables 6 and 7 , respectively. These protein variants are generally controlled by codominant genes so that the genotype of an animal can be established directly from the phenotype. Exceptions are the red cell adenosine deaminase and the serum albumin systems for which four phenotypes are governed by two codominant alleles $(A$ and $B)$ and a recessive " null » allele $(O)$.

Several genetic polymorphisms of proteins have been found by electrophoresis in other body fluids than blood or in tissue extracts. Since the first observations of GLASNÁ (1966), genetic variants of the sow's milk proteins have been reported, as reviewed by LARSEN (1971) and LYSTER (1972). The three main casein fractions $\left(\alpha-\mathrm{Cn}, \beta_{1}-\mathrm{Cn}\right.$ and $\beta_{2}-\mathrm{Cn}$ ) have been shown to be polymorphic ; see GlasNaK (1966, $1968 \mathrm{a}$, 1968 b), Gerrits et al. (1969) and Kemmer et al. (1972). Genetic variants have also been identified for whey proteins of porcine milk : $\beta$-lactoglobulin $(\beta-\mathrm{Lg})$ (KEMMER, 1969 ; Kraeling \& Gerrits, 1969 ; Bell et al., 1981 a), $\alpha$-lactalbumin ( $\alpha$-La) (SchmidT \& EBNER, 1972 ; Bell et al., $1981 \mathrm{~b}$ ), and the so-called whey ${ }_{2}$ protein (Althen \& Gerrits, 1972). Several polymorphic proteins of the seminal plasma of boars have been detected by Dostál $(1968,1970)$ and Dostál et al. (1976). One of the systems of lactate dehydrogenase isoenzyme (LDH-C) is polymorphic in boar spermatozoa (VALENTA et al., 1967). Apparently the same polymorphism of PHI enzyme as in red blood cells is demonstrable in extracts of liver (TARIVERDIAN, 1970) and in muscle (Gee \& Noltmann, 1981). Sorbitol dehydrogenase has been studied with kidney as a source material and this enzyme (SDH) is polymorphic with two codominant alleles (OP'T HoF et al., 1972). Genetic variants of pancreatic proteinase, controlled by two loci $\left(\mathrm{PPr}_{1}\right.$ and $\left.\mathrm{PPr}_{2}\right)$, have been identified by $\mathrm{T}_{\mathrm{AKAHASH}}$ et al. (1974).

\section{Linkages and syntenies}

Systematic search for genetic linkages in the pig has essentially dealt with polymorphic blood group and biochemical systems.

The first case of close linkage has been discovered by ANDRESEN \& BAKER (1964) and involves the $\mathrm{C}$ and $\mathrm{J}$ blood group systems. Additional data on the recombination frequency between genes at the $C$ and $J$ loci have been provided by RaSmuSEN (1965 b), ANDRESEn (1966 a) and Muir \& RaSmusen (1974) : the combined estimate of recombination frequency given by the latter authors is $5.7 \pm 0.8 \mathrm{p}$. 100. Thereafter, linkage of the pig main histocompatibility complex (SLA) and the $J$ blood group system has been demonstrated by HRUBAN et al. (1976), with a recombination frequency of 9.8 p. 100. As linkage between the $\mathrm{C}$ blood group locus and the SLA region has been further confirmed by Hruban et al. (1977), the linkage group including the $\mathrm{C}$ and $\mathrm{J}$ blood group loci and the SLA complex of loci (see above for more details on the SLA region) is established : the map order of these markers is SLA-J-C according to HRADECKÝ et al. (1982). 


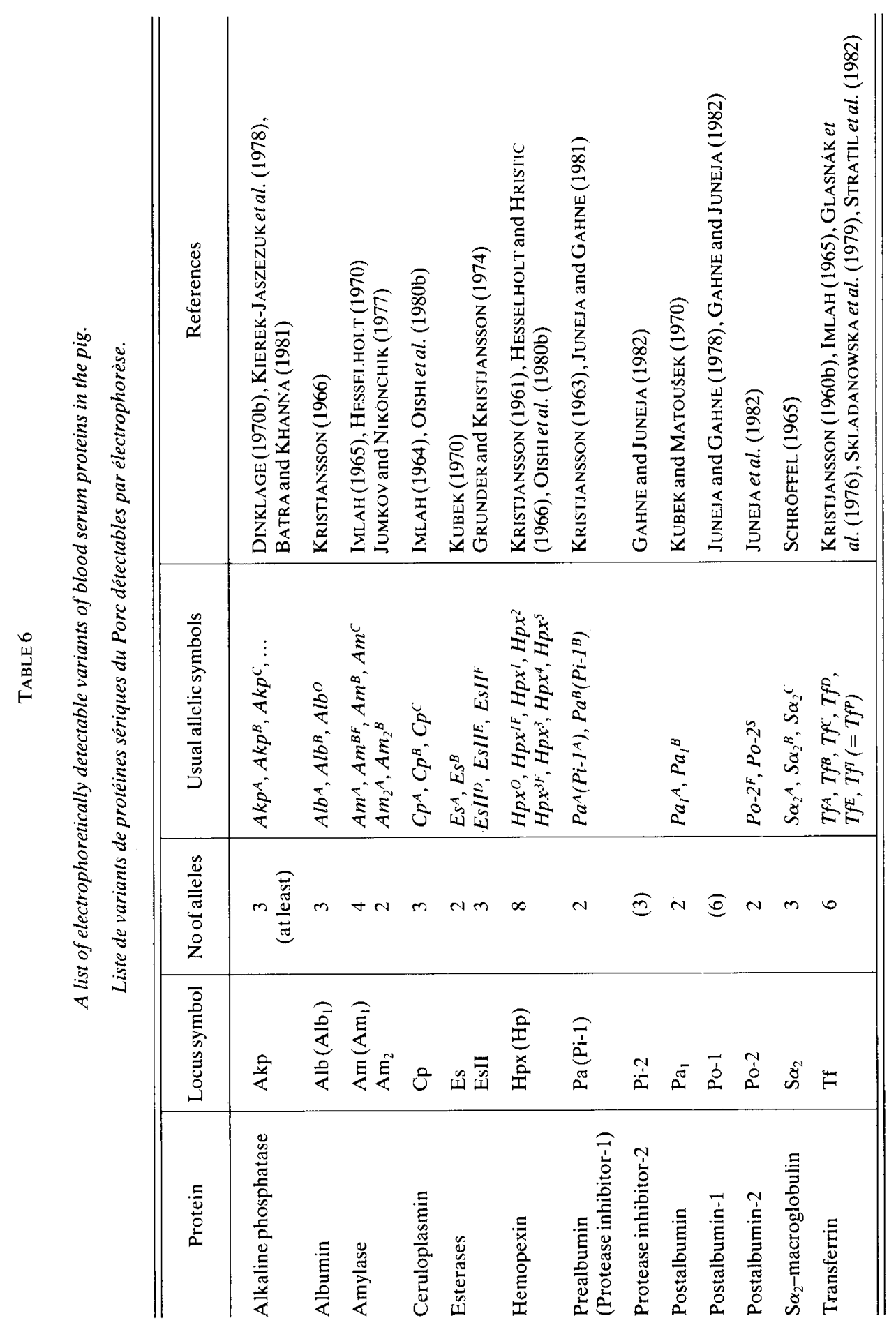




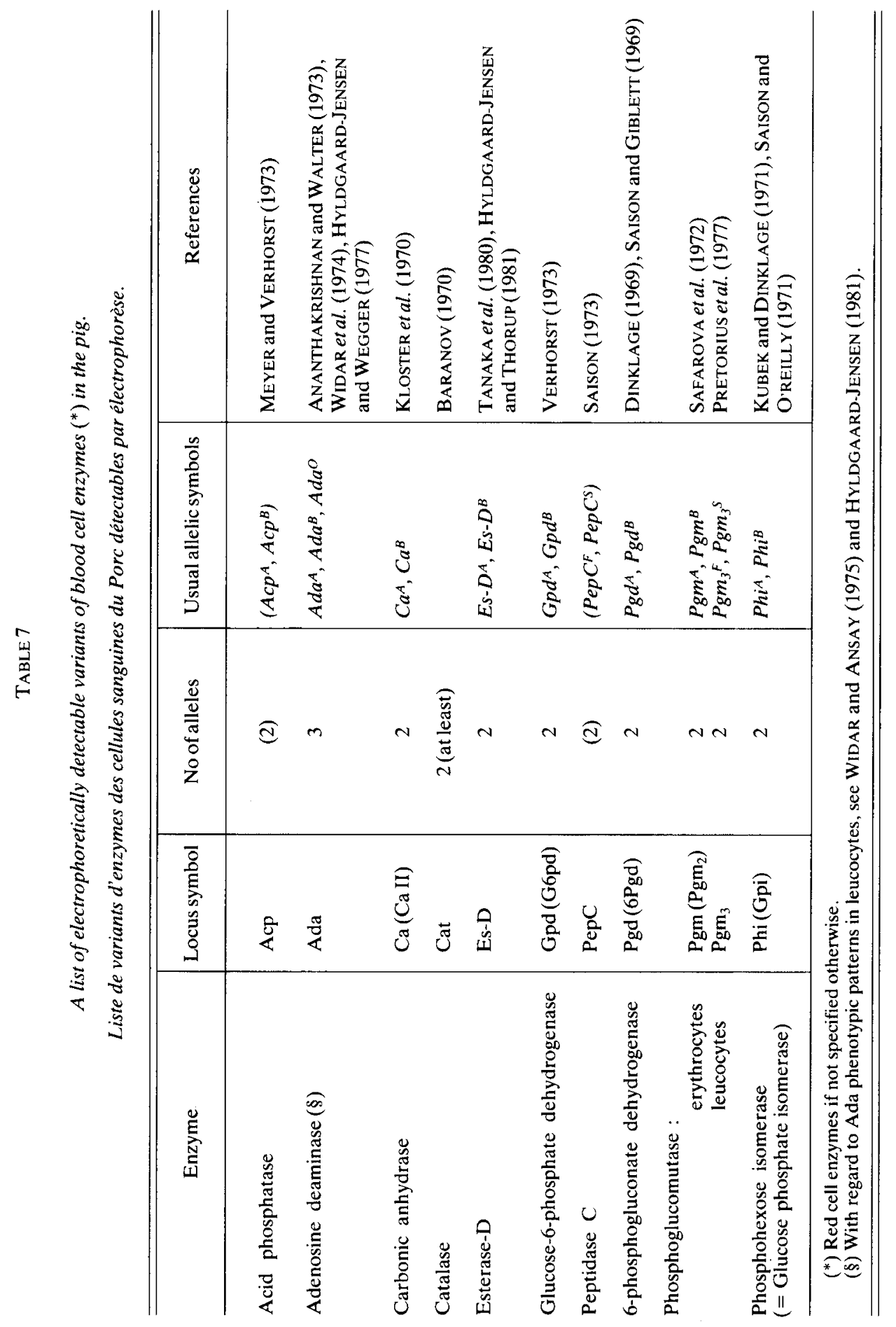


Linkage between the $\mathrm{K}$ blood group locus and the $\mathrm{Hpx}$ locus for hemopexin has been demonstrated by Imlah (1965), Andresen (1966 b) and Hesselholt \& Nielsen (1966). Combining segregation data from these three studies and their own study, HAGEN et al. (1968) have estimated at $3.8 \pm 0.5 \mathrm{p} .100$ the recombination frequency between $\mathrm{K}$ and $\mathrm{Hpx}$.

Close linkage between the Am locus for serum amylase and the I blood group locus has been found by ANDRESEN (1966 c) and NIELSEN (1966) : recombination frequency was 0.8 and 2.5 p. 100 , respectively.

The $\mathrm{H}$ blood group locus has been found to be closely linked to the Pgd locus for 6-phosphogluconate dehydrogenase and to the Phi locus for phosphohexose isomerase by ANDRESEN $(1970 \mathrm{a}, \mathrm{b})$. The recombination frequency between the two enzyme loci has been found higher than those between $\mathrm{H}$ and Phi and $\mathrm{H}$ and Pgd by the same author (ANDRESEN, 1971), according to whom the most likely order of the three loci is Phi-H-Pgd.

As first suggested by JøRGENSEN et al. (1976) on the basis of strong associations between halothane sensitivity and PHI phenotypes in several Landrace populations, close linkage between the $\mathrm{Hal}$ locus and the Phi locus has been demonstrated by ANDRESEN \& J JNSEN (1977, 1978 a) from segregation results in families. Mapping of the chromosomal region comprising the $\mathrm{Hal}, \mathrm{H}, \mathrm{Pgd}$ and Phi loci is currently under investigation. The following recombination frequencies (in p. 100) in this linkage group have been reported :

H-Pgd 3.4 (ANDRESEN 1970 a) ; 4.0 (RASMUSEN et al., 1980) ; $5.2 \pm 1.4$ (JøRGENSEN, 1981).

H-Phi 2.6 (ANDRESEN, 1970 b) ; 1.4 (RASMUSEN et al., 1980) ; 12.3 (IMLAh, 1980) ; $4.5 \pm 1.7$ (JøRGENSEN, 1981).

Pgd-Phi 8.1 (Andresen, 1971) ; 6.25 (Oishi \& Abe, 1979) ; 4.8 (Rasmusen et al., 1980) ; $12.4 \pm 4.6$ (JøRGENSEN, 1981);0.56 (GuÉRIN et al., 1983).

H-Hal 7.4 (IмLAH, 1980) ; $3.0 \pm 2.3$ (JøRGENSEN, 1981).

Pgd-Hal $9.1 \pm 6.3$ (Jørgensen, 1981) ; 1.18 (Guérin et al., 1983).

Phi-Hal 6.9 (IMLAH, 1980) ; no recombinant (JøRGENSEN, 1981) ; 0.73 (GUÉrin et al., 1983).

Note that the figures reported above for the study of RASMUSEN et al. (1980) correspond to the recombination frequencies pooled over the two sexes.

That the Hal locus is situated between the $\mathrm{H}$ and Phi loci has been deduced from relative linkage disequilibrium estimates by ANDRESEN (1979 a) and this hypothesis has been further accepted by RASMUSEN et al. (1980), IMLAH (1980) and JøRGENSEN (1981) : the most likely order is therefore Phi-Hal-H-Pgd according to these authors. However, GuÉRIN et al. (1983) have provided data in favour of the alternative order Hal-Phi-Pgd in this linkage group. In addition, as suggested by RASMUSEN et al. (1980), there might be a locus ( $S$ ) closely linked to but separate from the $\mathrm{H}$ locus for inhibition of expression of A-O blood group phenotypes : according to ANDRESEN (1981) and RASMUSEN (1981), data obtained so far are consistent with the following map order for the five loci : Phi-Hal-S-H-Pgd.

The locus Po-2 responsible for electrophoretic variants of a blood serum protein (postalbumin-2) has recently been assigned to the latter linkage group, with a recom- 
bination frequency of 3.2 p. 100 between Po-2 and Phi and with the Po-2 locus being probably located between the $\mathrm{H}$ and Pgd loci (Juneja et al., 1982). On the other hand, evidence for a loose linkage between the $\mathrm{H}$ blood group locus and the $\mathrm{C}$ and $\mathrm{J}$ blood group loci has been presented by RASMUSEN (1982), the frequencies of recombination being $42.4 \pm 3.0$ p. 100 for $\mathrm{H}$ and $\mathrm{C}$ and $41.7 \pm 3.5$ p. 100 for $\mathrm{H}$ and $\mathrm{J}$. All things together, it appears that nine polymorphic loci or systems, i.e. Hal, Phi, S, H, Po-2, Pgd, C, J and SLA, would be localized on the same chromosome : however, further data are needed to determine the exact gene order of this linkage group.

The loci for postalbumin-1 (Po-1) and protease inhibitor-1 (Pi-1) are closely linked according to GAHNE and JUNEJA (1982).

Possible linkage between two coat colour loci, E (extension) and $\mathrm{Be}$ (belt), has been reported by BuSHNELL (1943). Loose linkage between the B blood group locus and the Pa locus for serum prealbumin has been suggested by ANDRESEN (1968). There is some evidence of linkage between the genes controlling the different casein fractions of the sow's milk, according to GLASNAK (1968 b). An early lethal factor has been found to be linked to the Tf locus for transferrin (IMLAH, 1970 a). Linkage between genes controlling different immunoglobulin (IgG) allotypes has been shown by RAPACZ \& Hasler-Rapacz $(1974,1982)$. Close linkage between the SLB locus and the L blood group locus has been demonstrated by HRUBAN et al. (1978). Among the five lipoprotein allotype loci identified so far, three, i.e. Lpb, Lpt and Lpu, are closely linked, as reported by RAPACZ (1982).

Somatic cell hybridization techniques have recently been used for pig gene mapping. The first synteny, i.e. location on the same chromosome, for the genes controlling glucose6-phosphate dehydrogenase (G6PD), hypoxanthine guanine phosphoribosyltransferase (HPRT) and phosphoglycerate kinase (PGK) has been found by Gellin et al. (1980) and this syntenic group is to be assigned to the $\mathrm{X}$ chromosome according to Förster et al. (1980) and LEONG et al. (1982 a), as in all the mammalian species studied so far. The latter authors have also localized the gene for pig GLA ( $\alpha$-galactosidase) on the $X$ chromosome.

In addition to the above mentioned enzyme loci, the other cases of sex-linkage so far reported in pigs concern the splayleg condition (LAX, 1971) and the recessive gene responsible for the congenital tremor A III (HARDING et al., 1973).

The genes for pyruvate kinase (PKM2), mannose phosphate isomerase (MPI) and purine nucleoside phosphorylase (NP) have been shown to be syntenic by GeLLin et al. (1981).

The gene for superoxide dismutase (SOD1) has been assigned to the chromosome 9 of the pig karyotype by LEONG et al. (1982 b).

The study of linkage between natural or induced chromosomal rearrangements and blood group or biochemical markers has led FRIES et al. (1982) to provisionally assign the $G$ blood group locus to the pig chromosome 15. On the other hand, a loose linkage between the $\mathrm{G}$ and Hal loci had formerly been suggested by JøRGENSEN (1979) on the basis of associations between halothane sensitivity and $G$ blood group types. From this result and some of their own findings, FRIES et al. (1982) have suggested that, besides the G locus, the Phi-Hal-S-H-Pgd linkage group might also be located on the chromosome 15 . 


\section{Population studies}

A large number of studies have been devoted to estimating allelic frequencies in a variety of pig populations for the well-known polymorphic loci, particularly those controlling erythrocyte antigens, serum proteins and red blood cell enzymes.

In most studies, the populations involved are usual breeds or strains of Sus scrofa domestica : see, among others, GaVAlier et al. (1966), BAKER (1968), SмITH et al. (1968), Dinklage \& Gruhn (1969), Major et al. (1970), Willer \& Neuffer (1970), Meyer (1973), Verhorst et al. (1974), Widar et al. (1975), AgergaArd et al. (1976, 1977), Van Asten \& Buis (1977), and Oishi et al. (1978, 1979 b). Available information on gene frequencies at seven polymorphic loci ( $\mathrm{E}$ and $\mathrm{H}$ blood groups, Ada, Pgd, Phi, Hpx and $\mathrm{Tf}$ ) has been summarized by FRANCESCHI \& OLlivier (1981). Incidence of halothane sensitivity has also been extensively studied and the frequency of $\mathrm{Hal}^{\mathrm{s}}$ gene varies to a large extent in domestic pig breeds, as reviewed by Franceschi \& Ollivier (1981) and WebB et al. (1982). Particular attention has been given to breed differences in gene and haplotype frequencies for the linkage group containing the Hal, Phi, H and Pgd loci : e.g. Guérin et al. (1978, 1980), Andresen (1979 c), Jørgensen \& Hyldgand-Jensen (1981), Cepica et al. (1981, 1982), Andresen et al. (1981 b), and Vögel \& SChwörer (1982). As regards the pig major histocompatibility complex, present evidence on SLA haplotype frequencies in various breeds has been reviewed by RENARD et al. (1982).

Some studies have dealt with gene frequencies (especially for blood group systems) in pig populations such as native breeds or strains of miniature pigs (e.g. GRUHN \& Dinklage, 1971 ; Tikhonov \& Ratiany, 1973 ; Oishi \& Tomita, 1976 ; and Oishi et al., 1980 a) and populations of wild pigs (subspecies of Sus scrofa) distributed throughout the Eurasian continent (e.g. Buschmann, 1965 b ; Wiatroszak, 1970 ; TiKHONOV et al., 1972, 1974 ; and Kurosawa et al., 1979) or the North-American continent (e.g. Sмiтн et al., 1980).

\section{Performance traits}

Pig is primarily, if not exclusively, used as a source of animal proteins in human food and has a great economic importance in agriculture. As a consequence much attention has been devoted to the genetic control of the components of the overall efficiency of pigmeat production and, since LuSH (1937), to the application of genetics to the improvement of traits such as prolificacy, viability, growth rate or lean meat content of the carcass (e.g. Legault \& Ollivier, 1974 ; Jonsson, 1975 ; Cunningham, 1976 ; Fowler et al., 1976 ; FredeEn, 1980). Most of these traits show a continuous variation and the genetically controlled part of this variation depends on gene differences at many loci, the effects of which are not individually distinguishable. The methods of quantitative genetics (FALCONER, 1981; Ollivier, 1981) are relevant to the study of the polygenic inheritance of performance traits and have been extensively used. In the present review, no attempt will be made to give an exhaustive survey of this vast field of research. Our aim is only to summarize the current views on the nature of the genetic variation of quantitative traits and to guide the reader towards pertinent literature through a list of papers and reviews. Particular attention will be drawn to the respective importance of additive gene effects, as statistically assessed by heri- 
tability $\left(\mathrm{h}^{2}\right)$, and of non-additive gene effects (mainly dominance), as assessed by inbreeding depression and heterosis effect which respectively correspond to decreased and increased heterozygosity. Special emphasis will be put on the known influences of marker genes on performance traits (SPooner, 1974 ; Gahne, 1979 ; Oishi, 1979).

\section{A. Reproductive traits}

Prolificacy is a major component of reproductive performance of the pig. Additive genetic variance of number of youngs per litter, at farrowing or at weaning, is of low magnitude and heritability estimates are generally comprised between 5 and 15 p. 100 for litter size : e.g. Urban et al. (1966), Legault (1970), Strang \& King (1970), Revelle \& Robison (1973), Strang \& Smith (1979), Alsing et al. (1980), Johansson (1981), Johansson \& Kennedy (1982), and review by Bolet \& Legault (1982). In contrast, litter size is one of the traits which are the most affected by inbreeding depression (e.g. BERESKIN et al., 1968, 1973) and by heterosis in breed crosses, as reviewed by SELLIER $(1970,1976)$ and JOHNSON $(1981)$, these effects arising from the modified heterozygosity of the genotypes of both mother and youngs of the litter. Non-additive gene effects appear to be mainly responsible for the genetic variation of litter size or at least of prenatal and postnatal survival rate. Indeed ovulation rate, which is an entirely maternal component of litter size, has a moderately high heritability (30-40 p. 100 : e.g. Young et al., 1978 ; Legault \& Gruand, 1981) and has been successfully selected for (Cunningham et al., 1979 ; Pumfrey et al., 1980). On the other hand, ovulation rate does not exhibit heterosis to a significant extent (e.g. Johnson et al., 1978 ; Legault \& Gruand, 1981). Several specific genetic causes of prenatal mortality have been recognized. According to MC FEELY (1967), chromosomal abnormalities may explain about one third of the early embryonic mortality which itself affects one third of the fertilized eggs. Various immunogenetic incompatibilities and lethal factors also play a role in determining litter size through their incidence on fertilization rate and embryonic or neonatal loss (HANLY, 1961 ; ANDRESEN \& BAKER, 1963 ; Bishop, 1964 ; MatouŠEK, 1970 ; IMlah, 1970 a ; DunNe, 1975 ; GahNe, 1979). Lowered fertility and sterility of adult breeding animals, in some cases, result from aberrant chromosome complements : see FECHHEIMER (1981) for review.

The relationships between marker loci and reproductive traits have often been investigated. At least two studies (JENSEN et al., 1968 ; RASMUSEN \& HAGEN, 1973) support the hypothesis that genes at the $\mathrm{H}$ blood group locus significantly influence litter size, with a detrimental effect associated with the $H^{a}$ allele. The A blood group system, possibly because of the interrelationships between the $A$ and $H$ systems (see above), seems to be also involved, as well as other blood group factors to a lesser extent : e.g. Dinklage \& Hohenbrik (1970), Imlah (1972 b), Kennedy et al. (1973), HAGEN \& RASMUSEN (1974), and RASMUSEN (1975 b). Some authors have found associations between litter size or fertility of females and genes at the Tf locus for serum transferrin : e.g. Kristjansson (1964), Kuzmenko (1968 a, 1968 b), Imlah (1970 a), Tripathi \& Howell (1974), and RADOvic (1974); however, such associations have not been detected in other studies : e.g. Jensen et al. (1968), Fésüs \& Rasmusen (1971), KaWECKI et al. (1974), and HuANG \& RaSmusen (1982). Associations have also been reported between reproductive traits and the SLA complex (KRISTENSEN et al., 1980 ; VAIMAN \& RENARD, 1980 ; RENARD et al., 1982) or the monogenic halothane sensitivity (see WEBB et al., 1982). 
The genetic control of other characters conditioning the reproductive ability of breedings animals has also been investigated. Several aspects, such as intersexuality and other defects of the reproductive tract, the occurrence of abnormal teats and leg weakness, have been dealt with in previous sections. Age at puberty in gilts has a moderate heritability (around 30 p. 100) and generally exhibits heterosis in breed crosses : see Reutzel \& Sumption (1968), Young et al. (1978), Legault \& Gruand (1981), Hutchens et al. (1981), and the reviews of heterosis estimates by SEllier (1976) and JOHNSON (1981). Measurements of fertility of the breeding sow, such as conception rate or weaning to fertile mating interval, appear to be much more affected by nonadditive than by additive genetic effects : e.g. LeGault et al. (1975), Aumartre et al. (1976), JoHNSON et al. (1978), and FAHMY et al. (1979). Estimates of heritability for teat number range from 10 to 40 p. 100 and average approximately 30 p. 100, while heterosis effect is unimportant for this trait : e.g. Enfield \& Rempel (1961), SkJervold (1963), Hanset \& Camerlynck (1974), Pumfrey et al. (1980), and Clayton et al. (1981). Gestation length is moderately to highly heritable : e.g. Cox (1964), Fahmy \& Bernard (1972), and GARNETT \& RAHNEFELD (1979). Quantitative and qualitative aspects of semen production, as well as fertility, sexual precocity and libido of the boar, are affected, to some extent, both by additive and non-additive genetic effects : e.g. CLEM et al. (1967), Huhn (1970), du Mesnil du Buisson et al. (1974), Fahmy \& Holtmann (1977), Courot \& Legault (1977), Wilson et al. (1977), Conlon \& Kennedy (1978), Legault et al. (1979), and NeELy et al. (1980). Genetic aspects of specific causes of postnatal mortality, namely diseases and stress-induced sudden death (malignant hyperthermia syndrome), have been reviewed above.

\section{B. Growth and body composition traits}

Since the pioneer work of LuSH (1936) on the Danish Landrace breed, additive genetic variation of growth traits (average daily gain, efficiency of food utilization, age at slaughter) and body composition traits has been studied in a large variety of breeds, especially by analysing data of central testing stations : e.g. JoHANsson \& Korkman (1950), Osterhoff (1956), Smith et al. (1962), Smith \& Ross (1965), Langholz (1966), Jonsson (1963, 1965, 1974), Flock (1970), Ollivier (1970), Siers \& Thomson (1972), Hanset \& V V S S al. (1979), Kintaba et al. (1981), Ollivier et al. (1981), Ollivier \& Derrien (1981), and Kennedy et al. (1982). The heritability of postweaning growth rate and food conversion ratio is around $30 \mathrm{p} .100$. Daily food consumption (appetite) under ad libitum feeding is moderately to highly heritable: e.g. Mc PHEE et al. (1979) and WyLLIE et al. (1979). Estimates of heritability for carcass composition traits such as lean and fat percentages, lean to fat ratio, backfat thickness and loin eye area are generally in the neighbourhood of $50 \mathrm{p}$. 100. Heritability of carcass length is somewhat higher (about 60 p. 100), as well as that of number of vertebrae (e.g. Berge, 1948 ; FredeEn \& Newman, 1962). Additive gene effects are therefore a major source of variation of growth and carcass traits and large genetic gains for these two groups of traits have been achieved in several one-trait or multiple-trait selection experiments, as reviewed by GlodEK (1982). However, while carcass composition traits are not significantly influenced by inbreeding and heterosis, growth rate and feed efficiency are detrimentally affected by inbreeding and generally exhibit heterosis in breed crosses, indicating that non-additive gene effects are involved in the genetic control of the latter traits : see, for instance, KING \& RoBERTS (1959), BERESKIN et al. (1968), Mikami et al. (1977) and Leymaster \& Swiger (1981) for inbreeding effects and 
the surveys of heterosis estimates given by Seldier $(1970,1976)$ and Johnson (1981). Overall feed efficiency of the growing pig depends on several components (digestive utilization of nutrients, maintenance requirements, growth requirements) : available evidence on genetic influences on each of these components has been reviewed by Ollivier \& Henry (1978). Additive genetic variation appears to be of low to moderate magnitude for type, size and number of muscle fibres : e.g. STAun (1972) and Miller et al. (1975). Intramuscular fat content is highly heritable (Malmfors \& NiLsson, 1979), as well as the lipid content of the muscle (Duniec et al., 1961). There is limited evidence that fatty acid composition and content of adipose tissue are influenced by additive genetic factors (KellogG et al., 1977).

The phenomenon of muscular hypertrophy, which first appeared in the Belgian Piétrain breed, is a major feature of the genetic variation of body tissue composition in the pig and, as stated earlier, its hereditary determination is likely to be monogenic. A strong genetic association exists between halothane sensitivity and most carcass characters, especially those related to muscular development and muscle to bone ratio. At a given slaughter liveweight, halothane reactors give a significantly heavier, shorter and leaner carcass than non-reactors : e.g. Eikelenboom \& Minkema (1974), Monin et al. (1976, 1981), Eikelenboom et al. (1978), Ollivier et al. (1978), WebB \& JoRdan (1978), CARLSON et al. (1980), LAMPO (1981 b), and other reports reviewed by WEBB et al. (1982). In addition, there are indications that the heterozygote at the Hal locus may be intermediate between the two homozygotes with respect to killing out percentage and carcass lean content: see EIKELENBOOM et al. (1980), JENSEN \& ANDRESEN (1980), SCHNEIDER et al. (1980), JENSEN (1981), and WEBB (1981). The halothane gene, which is recessive for halothane sensitivity, would therefore be approximately additive for its effect on muscular development and body composition traits. Relationships between the latter traits and genotypes at the $\mathrm{H}$ and Phi loci, closely linked to Hal, have also been reported (e.g. Ansay \& Ollivier, 1978 ; Andresen \& Jensen, 1979 ; Guérin et al., 1979) : they may be explained by strong linkage disequilibria between the $\mathrm{H}$ or Phi locus and the Hal locus in the breeds involved.

As to other marker loci, no association with growth and body composition traits has been repeatedly found. Slight influences of various genetic systems have occasionally been reported but other authors have failed to detect any significant relationship : see Baltzer (1964), Jensen et al. (1968), Tripathi \& Howell (1969), Kraeling et al. (1971), Gavalier (1972), Kennedy et al. (1973), Ebermann et al. (1973), Wiatroszak (1974), Lengerken \& Pfeiffer (1974), Berndt et al. (1978), and CAPY et al. (1981).

\section{Meat quality traits}

Since 20 years, an increasing attention has been paid to a problem of great concern to the pork industry, namely the occurrence of abnormal meat quality, either PSE (pale, soft and exudative) meat (Briskey, 1964 ; Bendall \& Lawrie, 1964) or, to a lesser extent, DFD (dark, firm and dry) meat. As stated by Christian (1972), Cassens et al. (1975) and Sybesma \& Eikelenboom (1978), the changes which occur in the post mortem conversion of muscle to meat reflect the ante mortem condition of the musculature and are partly genetically determined. Since the first studies of JoNSSON (1963) and Ollivier \& MESLE (1963), additive genetic variances of such traits as $\mathrm{pH}$, colour and water binding capacity of meat have been estimated by several authors : e.g. Pease \& Smith (1965), Langholz (1966), Jensen et al. (1967), Flock (1968), WENiger et al. (1970), Walstra et al. (1972), Jonsson et al. (1972), StAun \& JENSEN (1974), 
Mc Gloughlin \& Mc Loughlin (1975), Lundström (1975), Scheper (1979), Malmfors \& Nilsson (1979), Schwörer et al. (1980), Lundeheim et al. (1980), and Ollivier et al. (1981). Heritability estimates for meat quality criteria are around 20-30 p. 100 . Effects of inbreeding and heterosis on the same traits are in general unimportant : e.g. Molenaar (1976), Young et al. (1976), Schneider et al. (1982), and earlier reports reviewed by SELLIER (1974).

There is no doubt that PSE meat condition and porcine stress syndrome (PSS) are associated phenomena, even though the relationship is not as simple as formerly anticipated (CASSENS et al., 1975). There is strong evidence that pigs which are susceptible to malignant hyperthermia syndrome, as detected by halothane sensitivity, are more likely to develop PSE meat condition: e.g. Eikelenboom \& Minkema (1974), Eikelenboom et al. (1978), Webb \& Jordan (1978), Mc Phee et al. (1979), Carlson et al. (1980), Mc Gloughlin et al. (1980), Jensen \& ANDRESEn (1980), Monin et al. (1981), and other reports reviewed by WEBв et al. (1982). Available comparisons between the three genotypes at the Hal locus with respect to meat colour are rather controversial as far as the exact position of the heterozygote is concerned : e.g. ANDRESEN \& Jensen (1978 b), Eikelenboom et al. (1980), Jensen \& Andresen (1980), SChneider et al. (1980), ANDRESEN et al. (1981 a), and WeBB (1981). On the other hand, higher incidences of the PSE condition of meat in animals possessing the $H^{a}$ allele at the $\mathrm{H}$ blood group locus and (or) the $P h^{B}$ allele at the locus for PHI enzyme have been found in several studies: Barton et al. (1977), ANDRESEN (1979 b), ANDrESEN \& Jensen (1979), Imlah \& Thomson (1979), Watanabe et al. (1979), Vögeli et al. (1980), JøRGENSEN (1981), FrøYstein et al. (1981), and Oishi et al. (1981). These findings are to be related to the associations observed between either $\mathrm{H}$ or PHI systems and halothane sensitivity (e.g. Rasmusen \& Christian, 1976 ; JøRgensen et al., 1976 ; JøRgensen, 1978 , 1979 ; Guérin et al., 1978 ; Hojny et al., 1979 c ; ANDRESEn, 1979 c, 1980 ; VöGeli \& SCHWÖRER, 1982) and can be explained by linkage disequilibria between loci of this chromosomal region in the breeds where the halothane sensitivity gene $\left(\mathrm{Hals}^{\mathrm{s}}\right)$ is preferentially associated with the $P h^{B}$ and $H^{a}$ genes.

With respect to the organoleptic quality of pigmeat, JonsSON \& WiSMER-PEDERSEN (1974), JoNSSON \& ANDRESEN (1979) and WILLEKE et al. (1980) have presented evidence for appreciable additive gene effects on the intensity of "sex odour " of meat from entire males, a defect (the so-called «boar taint») which is mainly due to a high concentration of a testicular steroid (androstenone) in the fatty tissue.

\section{Metabolic traits}

In recent years, a number of studies have dealt with the mode of inheritance of specific metabolic measurements, in an attempt to find new selection criteria which, in terms of potential genetic improvement, would be more efficient than the traditional " gross" measurements of performance. Examples of such genetic studies are given below.

Genetic differences have been reported for total plasma cholesterol concentration, which presents a moderate heritability : HeIdenreich et al. (1964), ReETZ et al. (1975), Rothschild \& Chapman (1976), Wegger (1978). Soluble protein content of fat tissue is moderately to highly heritable according to RogDakis \& STRUTZ (1978). A lipid mobilizing factor might be genetically controlled, as suggested by STANDAL et al. (1973). Heritability estimates for hemoglobin level have been provided by GABRIS (1974), 
ReEtz et al. (1975) and Fahmy \& Bernard (1978). Additive genetic effects have been reported for ceruloplasmin, copper and iron contents in blood plasma (REETZ \& FEDER, 1974) and for various blood cell counts in the young piglet (GABRIS, 1974). Blood glutathione content appears to be genetically controlled according to HYLDGAARD-JENSEN (1980). There is some evidence of genetic differences in the capacity for ascorbic acid synthesis according to Lund et al. (1980) and Palludan et al. (1982).

The quantitative activity of several enzymes has been studied from a genetic point of view. The arylesterase activity in blood serum shows a discontinuous variation which has been shown to be under the control of a set of multiple alleles by Augustinsson \& Olsson (1961), Gahne (1970) and Gahne et al. (1972). Activities of lipogenic enzymes (NADPH-generating dehydrogenases) in porcine adipose tissue are affected to a significant extent by additive gene effects (STRUTZ \& RoGDakIS, 1979). Evidence of genetic differences in glutathione peroxidase (GSH-Px) activity has been presented by JøRGENSEN et al. (1977). In the case of the adenosine deaminase (ADA) enzyme, which exhibits electrophoretic variants controlled by the Ada locus, as indicated earlier, it is worth mentioning that its erythrocytic quantitative activity seems to depend on the Ada genotype (WIDAR et al., 1974 ; HYLdgGaARD-JENSEN \& WEgGer, 1977) and also to be associated with susceptibility to lung infections (HYLDGAARD-JENSEN, 1978). Activity of serum alkaline phosphatase is influenced by genetic effects (IMLAH, 1970 b ; Locniskar et al., 1975), and PRZYTULSKI et al. (1982) have recently shown that the activity of this enzyme is related to the genotype at the Akp locus. In the same way, it has been suggested by BATRA et al. (1981) that serum amylase activity level could differ according to the Am phenotype based on electrophoresis. Several studies have shown that the activity level of creatine phosphokinase (CPK) enzyme in blood serum is influenced by additive gene effects, with heritability estimates generally falling in the range 20-50 p. 100 : e.g. Richter et al. (1973), Bickhardt et al. (1977), LAMPO (1980), Schworer et al. (1980), Schmitten et al. (1981), and review by BickhardT (1981). The halothane locus plays a major role in these genetic influences as halothane reactors present elevated serum $\mathrm{CPK}$ activities, as compared to non-reactors : see Bickhardt (1981) and WebB (1981) for review. Genetic influences, in particular those involving the Hal locus, have also been reported for blood serum activity levels of enzymes such as lactate dehydrogenase and aldolase, which like CPK mainly originate from skeletal muscle (e.g. LAMPO, 1981 a ; SCHMitTen et al., 1981), and for other quantitative blood parameters such as lactic acid content (e.g. Monin et al., 1979).

Reçu pour publication en septembre 1982

\section{Acknowledgments}

During the preparation of several sections of this review, the authors have benefited from the generous and competent advice of their colleagues G. GuÉRIN, J.-J. LAUVERGNE, C.-P. POPESCU (I.N.R.A., Génétique animale, Jouy-en-Josas) and M. VAIMAN (C.E.A., Radiobiologie appliquée, Jouy-en-Josas). Thanks are also due to $\mathrm{D}^{\text {rs }}$ E. ANDRESEN (Copenhagen, Denmark), V. HRuBan (Liběchov, Czechoslovakia), R.K. JUNEJA (Uppsala, Sweden) and B.A. RASmuSEN (Urbana, Illinois, U.S.A.) who have kindly provided us with up-to-date information on biochemical polymorphism and linkage groups in pigs. The help of Françoise Bouchain, Irène Cabourdin, Josette Delavault, Claire Mesnigé, Annie PECH and Marie-Reine Perretant in preparing the manuscript is gratefully acknowledged. 


\section{Résumé \\ La génétique du porc : mise au point}

Une mise au point générale sur la génétique du porc est faite. Les principaux domaines couverts sont : caryotype et anomalies chromosomiques, couleur de la robe, anomalies héréditaires, résistance aux maladies, immunogénétique, polymorphismes biochimiques, "linkages " et synténies, caractères quantitatifs d'importance économique. Sur ce dernier point, une attention particulière est accordée aux influences connues de gènes marqueurs sur les caractères zootechniques. Des listes de gènes gouvernant la couleur de la robe, les groupes sanguins (antigènes érythrocytaires) et les variants électrophorétiques de protéines sériques et d'enzymes des cellules sanguines sont présentées dans des tableaux. Une liste de 29 anomalies génétiques qui peuvent être considérées comme probablement monogéniques chez le porc est également donnée. Le nombre total de locus actuellement identifiés avoisine 100.

\section{References}

AAmDAl J., Nes N., 1958. Persistent frenulum praeputii as a cause of mating impotence in boars (in Norwegian). Nord. Vet.-Med., 10, 444-446.

Agergaard N., Hyldgaard-Jensen J., Jøŕgensen P.F., Nielsen P.B., Moustgaard J., 1976. Biochemical-genetic constitution of Danish Landrace pigs : an immunogenetic and biochemical study. Acta Agric. scand., 26, 255-263.

Agergaard N., Hyldgaard-Jensen J., Nielsen P.B., Moustgaard J., 1977. Blood groups and breed differences in pigs. A comparative immunogenetic and biocheminal-genetic study (in Danish). Aarsberetn. Inst. Sterelitetsforsk. 1977, 81-92.

Agergatidd N., Nielsen P.B., 1978. Pig blood groups. A survey of the occurrence, determination and application (in Danish). Aarsberetn. Inst. Sterelitetsforsk. 1978, 67-84.

Alsing I., KRIPPL J., Pirchner F., 1980. Maternal effects on the heritability of litter traits of pigs. Z. Tierzücht. ZüchtBiol., 97, 241-249.

Althen T.G., Gerrits R.J., 1972. Polymorphism of whey ${ }_{2}$ protein of sow's milk. J. Dairy Sci., 55, 331-332.

ANANTHAKRISHNAN R., WALTER H., 1973. Electrophoretic variation of adenosine deaminase (ADA) in pigs. Z. Saügetierk., 38, 318-320.

ANDERSEN K., FIlSETh O., 1976. The occurrence of a « SME »-defect-like abnormality in the head of spermatozoa from a Nonvegian Landrace boar. Nord Vet.-Med., 28, 511-514.

ANDRESEN E., 1957. Investigations on blood groups of the pig. Nord Vet.-Med., 9, 274-284.

ANDRESEN E., 1962. Blood groups in pigs. Ann. N.Y. Acad. Sci., 97, 205-225.

ANDRESEN E., 1964. The inheritance of the blood factors $I_{a}$ and $I_{b}$ in pigs of the Duroc and Hampshire breeds. Vox Sang., 9, 617-621.

ANDRESEN E., 1966 a. Additional linkage data involving the $\mathrm{C}$ and $\mathrm{J}$ blood group loci in pigs. Vox Sang., 11, 120-123.

ANDRESEN E., $1966 \mathrm{~b}$. Linkage between the K blood group locus and the Hp locus for hematinbinding globulins in pigs. Genetics, 54, 805-812.

ANDRESEN E., $1966 \mathrm{c}$. Blood groups of the I system in pigs : association with variants of serum amylase. Science, 153, 1660-1661.

ANDRESEN E., 1968. Sequential analysis of genetic linkage in pigs. K. Vet.-og. Landbohøjsk Aarsskr., 1968, 1-11.

ANDRESEN E., 1970 a. Linkage between the $\mathrm{H}$ and 6-PGD loci in pigs. Acta vet. scand., 11, 136-137.

ANDRESEN E., $1970 \mathrm{~b}$. Close linkage between the locus for phosphohexose isomerase (PHI) and the $\mathrm{H}$ blood group locus in pigs. Anim. Blood Grps biochem. Genet., 1, 171-172.

ANDRESEN E., 1971. Linear sequence of the autosomal loci PHI, H and 6-PGD in pigs. Anim. Blood Grps biochem. Genet., 2, 119-120. 
ANDRESEN E., 1979 a. Evidence indicating the sequence Phi, Hal, $\mathrm{H}$ of the three closely linked loci in pigs. Nord. Vet.-Med., 31, 443-444.

ANDRESEN E., $1979 \mathrm{~b}$. Associative additive effects of alleles of the $\mathrm{H}$ and PHI loci on the quality of meat from Danish Landrace pigs. Acta Agric. scand., 29, 321-325.

ANDRESEN E., 1979 c. Linkage disequilibrium responsible for association between susceptibility to the malignant hyperthermia syndrome (MHS) and PHI types in Danish Landrace pigs. Acta Agric. scand., 29, 369-373.

ANDRESEN E., 1980. Association between susceptibility to the malignant hyperthermia syndrome (MHS) and $\mathrm{H}$ blood types in Danish Landrace pigs explained by linkage disequilibrium. Livest. Prod. Sci., 7, 155-162.

ANDRESEN E., 1981. Evidence for a five-locus linkage group involving direct and associative interactions with the $A-O$ blood group locus in pigs. In : BRUMMERSTEDT E. (Ed.), Papers dedicated to Professor Johannes Moustgaard on the occasion of his 70th birthday, 208-212, Royal Danish Agricultural Society, Copenhagen.

ANDResen E., BAKer L.N., 1963. Hemolytic disease in pigs caused by anti-Ba. J. Anim. Sci., 22, 720-725.

ANDRESEN E., BAKER L.N., 1964. The C blood group system in pigs and the detection and estimation of linkage between the $\mathrm{C}$ and $\mathrm{J}$ systems. Genetics, 49, 379-386.

ANDRESEN E., IRWIN M.R., 1959. The K blood group system of the pig. Acta Agric. scand., 9, 253-260.

ANDRESEN E., JENSEN P., 1977. Close linkage established between the HAL locus for halothane sensitivity and the PHI (phosphohexose isomerase) locus in pigs of the Danish Landrace breed. Nord. Vet.-Med., 29, 502-504.

ANDRESEN E., JENSEN, 1978 a. The HAL-PHI linkage demonstrated by segregation among paternal sibs of Danish Landrace pigs. Nord. Vet.-Med., 30, 37-38.

ANDRESEN E., JENSEN P., 1978 b. Evidence of an additive effect of alleles of the HAL locus on the KK index for porcine meat quality. Nord. Vet.-Med., 30, 286-288.

ANDRESEN E., JENSEN P., 1979. Functional additive effect of $\mathrm{H}$ blood group alleles on carcass length in Danish Landrace pigs. Nord. Vet.-Med., 31, 229-232.

ANDRESEn E., Jensen P., Barton-Gade P., 1981 a. The porcine Hal locus : a major locus exhibiting overdominance, Z. Tierzücht, ZüchtBiol., 98, 170-175.

Andresen E., Jensen P., Jonsson P., 1981 b. Population studies of Phi, Hal, $H$ haplotype frequencies and linkage disequilibria in Danish Landrace pigs. Z. Tierzücht. ZüchtBiol., 98, 45-54.

ANDRESEn E., Rapacz J., Hasler-RapaCz J., 1976. Low-density $\beta$-lipoproteins (LDL) in swine : investigations of linkage relationships. Anim. Blood Grps biochem. Genet., 7, 185-186.

ANDResen E., Wroblewski A., 1961. The $\mathrm{G}$ and $\mathrm{H}$ blood group systems of the pig. Acta vet. scand., 3, 267-280.

ANNETt H.E., 1938. A new ear-defect in pigs. J. Hered., 29, 469-470.

ANonymous, 1981. Pig blood group comparison test 1980. Anim. Blood Grps biochem. Genet., 12, 219-224.

Ansay M. Ollivier L., 1978. Créatinine plasmatique et sensibilité du porc au syndrome d'hyperthermie maligne. Relations avec deux enzymes du globule rouge (PHI et 6-PGD). Ann. Génét. Sél. anim., 10, 9-16.

Ashton G.C., 1957. Zone electrophoresis of mammalian sera in starch gels. Nature, Lond., 179, 824-825.

AsHTON G.C., 1960. Thread protein and $\beta$-globulin polymorphism in the serum proteins of pigs. Nature, Lond., 186, 991-992.

Asten P.H.F.M. Van, Buis R.C., 1977. Gene frequencies of blood groups in Dutch swine breeds. Anim. Blood Grps biochem. Genet., 8, 39-43.

Augustinsson K.B., Olsson B., 1961. Genetic control of arylesterase in the pig. Hereditas, 47, 1-22.

Aumaitre A., Dagorn J., Legault C., Le Denmat M., 1976. Influence of farm management and breed type on sow's conception-weaning interval and productivity in France. Livest. Prod. Sci., 3, 75-83. 
Backström L., Henricson B., 1971. Intersexuality in the pig. Acta vet. scand., 12, $257-273$.

BAKER L.N., 1968. Serum protein variation in Duroc and Hampshire pigs. Vox Sang., 15 , 154-158.

BAKER L.N., 1971. E red cell system in pigs: irregular genetic transmission, Vox Sang., 21, $57-64$.

Baker L.N., Andresen E., 1962. The B blood groups in swine. Genetics, 47, 940 (Abstr.). BAKer L.N., Andresen E., 1964. The $B_{b}$ blood group factor in pigs. Vox Sang., 9, 359-362.

BALTZER J., 1964. Untersuchungen über das Bestehen von Beziehungen zwischen Blutgruppenfaktoren und Daten des Schlachtkörperwertes und der Mastleistung des Schweines. Züchtungskunde, 36, 317-326.

BARANOV O.K., 1970. An immunoelectrophoretic study of protein polymorphism in hemolysates of pigs and cattle. Biochem. Genet., 4, 549-563.

Barton P., Jørgensen P.F., Nielsen P.B., Moustgaard J., 1977. Blood types and meat quality in swine (in Danish). Aarsberetn. Inst. Sterelitetsforsk. 1977, 93-100.

Batra T.S., KhanNa N.D., 1981. Note on the genetic polymorphism of alkaline phosphatase in pigs. Indian J. Anim. Sci., 51, 111-112.

Batra T.S., Khanna N.D., Tandon S.N., EAPEN K.J., 1981. Genetic study on the serumamylase system of pigs. Indian J. Anim. Sci., 51, 720-723.

BEER J., 1962. Ein Erbfehler mit multiplen Anomalien beim Schwein und sein aussergewöhnlicher Erbgang. Zuchthyg. FortpflStör. Besam. Haustiere, 6, 353-370.

Bell K., MC Kenzie H.A., Shaw D.C., 1981 a. Porcine $\beta$-lactoglobin A and C. Occurrence, isolation and chemical properties. Molec. Cell. Biochem., 35, 103-111.

Bell K., MC Kenzie H.A., Shaw D.C., 1981 b. Porcine $\alpha$-lactalbumin A and B. Molec. Cell. Biochem., 35, 113-119.

Bendall J.R., Lawrie R.A., 1964. Watery pork. Anim. Breed. Abstr., 32, 1-8.

Bereskin B., 1979. Genetic aspects of feet and legs soundness in swine. J. Anim. Sci., 48, 1322-1328.

Bereskin B., Shelby C.E., Cox D.F., 1973. Some factors affecting pig survival. J. Anim. Sci., 36, 821-827.

Bereskin B., Shelby C.E., Rowe K.E., Urban W.E. Jr, Blunn C.T., Chapman A.B., Garwood V.A., Hazel L.N., Lasley J.F., Magee W.T., MC Carty J.W., Whatley J.A. Jr, 1968. Inbreeding and swine productivity traits. J. Anim. Sci., 27, 339-350.

BERGE S., 1941. Three hereditary anomalies in pigs. Hereditas, 27, 176-192.

BERGE S., 1948. Genetical researches on the number of vertebrae in the pig. J. Anim. Sci., 7, 233-238.

BERGE S., 1961. Heredity of colour in pigs (in Norwegian). Tidsskr. norske Landbr., 68, 159-188.

Berndt W., Pilz J., BlüMel J., 1978. Untersuchugensergebnisse über Beziehungen zwischen Blutgruppenfaktoren bzw. Allelen und Leistungsmerkmalen beim Schwein. Arch. Tierz., 21, 349-358.

Berruecos J.M., Robinson O.W., 1972. Inheritance of gastric ulcers in swine. J. Anim. Sci., 35, 20-24.

BERTHA B., 1975. Occurrence of tremor and splayleg in piglets. Magy. Allatorv. Lap., 30, 413-416.

BickhardT K., 1981. Blood enzyme test. In : Frøystein T., Slinde E. and Standal N. (Eds), Porcine stress and meat quality: causes and possible solutions to the problems, 125-134, Agricultural Food Research Society, Ås, Norway.

BickhardT K., Chevalier H.J., Tuch K., 1975. Zur Ätiologie und Pathogenese der Akuten Ruckenmuskelnekrose des Schweines. Dt. tierärztl. Wsch., 82, 475-479.

BickhardT K., Flock D.K., Richter L., 1977. Creatine-kinase test (CK test) as a selection criterion to estimate stress resistance and meat quality in pigs. Vet. Sci. Commun., 1, 225-233.

Bishop M.W.H., 1964. Paternal contribution to embryonic death. J. Reprod. Fert., 7, 383-396.

Bishop M.W.H., 1972. Genetically determined abnormalities of the reproductive system. J. Reprod. Fert., suppl., 15, 51-78. 
BLom E., 1973. Studies on boar semen. I. A new major defect in the sperm head, the SME defect. Acta vet. scand., 14, 633-635.

Blom E., JenSEN P., 1977. Study of the inheritance of the SME seminal defect in the boar. Nord. Vet.-Med., 29, 194-198.

BlunN C.T., Hughes E.H., 1938. Hydrocephalus in swine. J. Hered., 29, 203-208.

Bogart R., Muhrer M.E., 1942. The inheritance of a hemophilia-like condition in swine. J. Hered., 33, 59-64.

Bolet G., Legault C., 1982. Nuevas consideraciones sobre la mejora genética de la prolificidad en el cerdo. In : 2nd World Congress on Genetics applied to Livestock Production, V, 548-567, Editorial Garsi, Madrid.

Bosma A.A., 1976. Chromosomal polymorphism and G-banding patterns in the wild boar (Sus scrofa L.) from the Netherlands. Genetica, 46, 391-399.

Bosma A.A., Colenbrander B., Wensing C.J.G., 1975. Studies on phenotypically female pigs with hernia inguinalis and ovarian aplasia. II. Cytogenetical aspects. Proc. Kon. Ned. Akad. Wet. C $78,1,43-46$.

Bouw J., Osterlee C.C., 1969. Bloodgroups in animals (in Dutch). Tijdschr. Diergeneesk., 94, 109-137.

Bradley B.A., White D.J., Edwards J.M., 1974. Restriction of polymorphisms defined by mixed lymphocyte reactions in the pig. Tissue Antigens, 4, 283-290.

Bradley R., Wells G.A.H., 1978. Developmental muscle disorders in the pig. Vet. A., 18, 144-157.

Bradley R., Wells G.A.H., Gray L.J., 1979. Back muscle necrosis of the pig. Vet. Rec., 104, 183-187.

BreeuwSma A.J., 1970. Studies on intersexuality in pigs. Doktorate thesis, Univ. of Utrecht.

Bring-Larsson K., Sundgren P.E., 1977. Studies on locomotory disturbances in pigs (in Swedish). LantbrHögsk. Meddn A. 284, 30 p.

BRISKEY E.J., 1964. Etiological status and associated studies of pale, soft, exudative porcine musculature. Adv. Fd Res., 13, 89-94.

Britt B.A., Kalow W., Endrenyl L., 1978. Malignant hyperthermia. Pattern of inheritance in swine. In : ALDRETE J.A. and BRITT B.A. (Eds), Second International Symposium on Malignant Hyperthermia, 195-211, Grune and Stratton, New York.

Brooksbank N.H., 1958. Congenital deformity of the tail in pigs. Br. vet. J., 114, 50-55.

Brucks R., 1966. A study of the K blood group system of swine. In : Polymorphismes Biochimiques des Animaux, 167-170, Institut National de la Recherche Agronomique, Paris.

BuschmanN H., 1965 a. Uber erbliche biochemische Systeme bei den Haustieren. Z. Tierzücht. ZüchtBiol., 81, 370-388.

BuschmanN H., 1965 b. Blood group studies in pigs. In : MAtoušEK J. (Ed.), Blood Groups of Animals, 129-136, Publishing House of the Czechoslovak Academy of Sciences, Prague.

Buschmann H., Schmid D.O., 1968. Serumgruppen bei Tieren, Paul Parey, Berlin and Hamburg.

BUSHNELL R.L., 1943. Linked color factors in Hampshire swine. Linkage of black and the basic white of the white belt pattern. J. Hered., 34, 303-306.

BUTZ H., MEYER H., 1960. Uber einen Zuchtversuch bei Schweinen mit Lippenkiefergaumenspalten. Dt. tierärztl. Wschr., 67, 522-525.

Butz H., Schnelle W., 1951. Angeborene Lähmung der Hinterextremitäten beim Ferkel. Dt tierärztl. Wschr., 58, 206-207.

Cameron H.S., Gregory P.W., Hugues E.H., 1943. Inherited resistance to brucellosis in inbred Berkshire swine. Am. J. vet. Res., 4, 387-389.

Capy P., Renard C., Sellier P., Vaiman M., 1981. Etude préliminaire des relations entre le complexe majeur d'histocompatibilité (SLA) et des caractères de production chez le porc. Ann. Génét. Sél. anim., 13, 441-446.

Carlson J.P., Christian L.L., Kuhlers D.L., Rasmusen B.A., 1980. Influence of the porcine stress syndrome on production and carcass traits. J. Anim. Sci., 50, 21-28. 
Carr-Saunders A.M., 1922. Note on inheritance in swine. Science, 55, 19.

Cassens R.G., Marple D.N., Eikelenboom G., 1975. Animal physiology and meat quality. Adv. Fd Res., 21, 71-155.

CASTlE W.E., 1940. Mammalian Genetics, Harvard University Press, Cambridge, Mass., U.S.A.

Cela M., Colombani B., 1972. Cytogenetic and radiographic observations on pigs with skeletal malformations (in Italian). Annali Fac. Med. vet. Univ. Pisa, 25, 81-88.

Cepica S., Hojný J., Hradecky J., Klaudy J., 1982. A study on the sensitivity to halothane and associations between $\mathrm{Hal}$ and $\mathrm{Phi}, \mathrm{H}, \mathrm{A}$ and $\mathrm{S}$ loci in the pigs of Prestitzer Black-Pied breed (in Czech.) Zivoc. Vyroba, 27, 587-593.

CePiCa S., Hojný J., Linhardt J., 1981. Frequencies of alleles of phosphohexose isomerase and of $\mathrm{H}$ and $\mathrm{A}$ blood group systems with regard to the possibility of utilizing them for the selection against the porcine stress syndrome (in Czech.). Zivoc. Vyroba, 26, 641-646.

ChARDON P., RENARD C., VAIMAN M., 1981. Characterization of class II histocompatibility antigens in pigs. Anim. Blood Grps biochem. Genet., 12, 59-65.

Christensen K., SMEdegÅrd K., 1978. Chromosome marker in domestic pigs. C-band polymorphism. Hereditas, 88, 269-272.

Christensen K., SMEdegård K., 1979. Chromosome markers in domestic pigs. A new C-band polymorphism. Hereditas, 90, 303-304.

Christian L.L., 1972. A review of the role of genetics in animal stress susceptibility and meat quality. In : Cassens R., Giesler F. and Kolb Q. (Eds), The Proceedings of the Pork Quality Symposium, 91-115, University of Wisconsin, Madison, U.S.A.

Clayton G.A., Powell J.C., Hiley P.G., 1981. Inheritance of teat number and teat inversion in pigs. Anim. Prod., 33, 299-304.

Clem D.R., Plotka E.D., Garwood V.A., Foley C.W., 1967. Heritabilities and correlations among boar semen traits. J. Anim. Sci., 26, 1464-1465.

Cohrs P., Comberg G., Meyer H., Trautwein G., 1963. Erbliche Meningocele cerebralis beim Schwein. Dt. tierärztl. Wschr., 70, 437-440.

Colenbrander B., Wensing C.J.G., 1975. Studies on phenotypically female pigs with hernia inguinalis and ovarian aplasia. I. Morphological aspects. Proc. Kon. Ned. Akad. Wet. C 78, 1, 33-42.

CONLON P.D., KENNEDY B.W., 1978. A comparison of crossbred and purebred boars for semen and reproductive characteristics. Can. J. Anim. Sci., 58, 63-70.

CONSTANTINESCU G.K., 1933. Vererbungsversuche an Schweinen unter besonderer Berücksichtigung des Mangalitza Schweines. Z. Zücht. B, 26, 395-427.

CONSTANTinesCU G.K., 1934. Recherches sur le croisement de la race Mangalitza avec la race Large Black. Anal. Inst. natn. zooteh., 3, 13-34.

CONSTANTINESCU G.K., 1935. Neue Untersuchugen über die Vererbung bei Schweinen. Kreuzungen Zwischen Mangalitza und Lincoln. Anal. Inst. natn. zooteh., 4, 93-116.

CorCoran C.J., 1964. Pityriasis rosea in pigs. Vet. Rec., 76, 1407-1409.

Cordes D.O., Dodd D.C., 1965. Bilateral renal hypoplasia of the pig. Pathologia Vet., 2, 37-48.

Courot M., Legault C., 1977. Analyse génétique de la production spermatique du jeune verrat de race Large White : résultats préliminaires. In : Journées de la Recherche Porcine en France 1977, 75-78, Institut Technique du Porc, Paris.

Cox D.F., 1964. Genetic variation in the gestation period of swine. J. Anim. Sci., 23, 746-751.

Cunningham E.P., 1976. Current developments in the genetics of livestock improvement. Anim. Blood Grps biochem. Genet., 7, 191-200.

Cunningham P.J., England M.E., Young L.D., Zimmerman R.D., 1979. Selection for ovulation rate in swine: correlated response in litter size and weight. J. Anim. Sci., 48, 509-516.

CWIK S., Weber-OeChSNer K., SChmid O.D., 1981. B-lymphozytenantigene beim Schwein und ihr Nachweis. Zentbl. Vet.-Med., 28, 310-318.

DabCZEwSKI Z., 1949. Studies on a teratological form of the newly born Pulawska swine (in Polish). Bull. int. Acad. Pol. Sci. Lett., Cl. Sci. math. nat., B II Zool., 241-260.

Dechambre P., 1925. L'hybridation du sanglier et du porc. Revue Hist. nat. appl., 6, 207-212. 
Dechambre P., 1929. Etudes génétiques sur les porcs et les sangliers. Recl Méd. vét. Ec. Alfort, 105, 129-184.

Detlefson J.A., Carmichael W.J., 1921. Inheritance of syndactylism, black and dilution in swine. J. agric. Res., 20, 595-604.

DinKLAGE H., 1969. 6-phosphogluconat-dehydrogenase-polymorphismus beim Schwein. Züchtungskunde, 41, 326-330.

DiNKLAGE H., 1970 a. Results of the third pig blood grouping comparison test. In : XIth European Conference on Animal Blood Groups and Biochemical Polymorphism, 359-361, Polish Scientific Publishers, Warsaw.

DinKLAGE H., 1970 b. The alkaline phosphatase system in the pig. In : XIth European Conference on Animal Blood Groups and Biochemical Polymorphism, 329-330, Polish Scientific Publishers, Warsaw.

Dinklage H., GruHn R., 1969. Blutgruppen- und Serumproteinpolymorphismus bei verschiedenen in Deutschland vorhandenen Schweinerassen. Z. Tierzücht. ZüchtBiol., 86, 136-146.

DiNKLAGE H., HoHENBRIK R., 1970. Untersuchung über den Einfluss heterozygoter Blutgruppengenorte auf Merkmale der Zuchtleistung bei der Deutschen Landrasse. Züchtungskunde, 42, 284-293.

DONALD H.P., 1949. The inheritance of a tail abnormality associated with urogenital disorders in pigs. J. agric. Sci., Camb., 39, 164-173.

Donald H.P., 1951. Genetic variation in colour pattern of Wessex Saddleback pigs. J. agric. Sci., Camb., 41, 214-221.

DONE J.T., 1968. Congenital nervous diseases of pigs : a review. Lab. Anim., 2, 207-217.

DONE J.T., 1976 a. The congenital tremor syndrome in pigs. Vet. A., 16, 98-102.

DONE J.T., 1976 b. Development disorders of the nervous system in animals. Adv. vet. Sci. comp. Med., 20, 69-114.

DONE J.T., 1977. Facial deformity in pigs. Vet. A., 17, 96-102.

DONE J.T., 1978. Congenital motor defect ("spastic") in pigs (Personal communication).

Done J.T., Allen W.M., Bailey J., Gruchy P.H. de, CurRan M.K., 1975. Asymmetric hindquarter syndrom (AHQS) in the pig. Vet. Rec., 96, 482-488.

DONE J.T., LOOSMORE R.M., SAunders C.N., 1967. Dermatosis vegetans in pigs. Vet. Rec., 80, 292-297.

Done J.T., Wijeratne W.V.S., 1972. Genetic disease in pigs. In : Cole D.J.A. (Ed.), Pig Production, 53-67, Butterworths, London.

Dostál J., 1968. A study on polymorphic proteins of seminal vesicle fluid and seminal plasma in boars. Immunogenetics Letter, 5, 117-119.

Dostál J., 1970. Protein polymorphism in boar seminal plasma. In : XIth European Conference on Animal Blood Groups and Biochemical Polymorphism, 297-300, Polish Scientific Publishers, Warsaw.

Dostál J., Veselsky L., Jílek F., 1976. Properties of the boar prostatic polymorphic protein. In : VIIIth International Congress on Animal Reproduction and Artifical Insemination, vol. I, 71 (Abstr.).

DRY F.W., COOPER M. MC G., 1945. Colour inheritance in crossbred pigs of Large WhiteTamworth origin. N.Z. Jl Sci. Technol., 27, 64-71.

Duniec H., KIElanowski J., OSINSKa Z., 1961. Heritability of chemical fat content in the loin muscle of baconers. Anim. Prod., 3, 195-198.

DUNIEC M., 1972. Preliminary investigations on two blood serum antigens in pigs. In : Kovács G. and PAPP M. (Eds), XIIth European Conference on Animal Blood Groups and Biochemical Polymorphism, 285-287, Akadémiai Kiadó, Budapest.

DUNNE H.W., 1975. Abortion, stillbirth, fetal death and infectious infertility. In : DUNNE H.W. and Leman A.D. (Eds), Diseases of Swine, Iowa State University Press, Ames, Iowa, U.S.A.

DuRHAM G.B., 1921. Inheritance of belting spotting in cattle and swine. Am. Nat., 55, 476-477. DürR M., 1937. Die Vererbung der Glasäugigkeit beim Schwein. Z. Zücht. B, 37, 129-158.

Ebermann R., Barna J., Kutscha-Lissberg P., Leitgeb R., 1973. Der Einfluss der polymorphen Präalbumine im Schweineserum auf Futterverwertung und Schlachtkörperzusammensetzung von Osterreichischen Edel- und Landrasse- Schweinen. Züchtungskunde, 45, 133-139. 
Edfors-Lilja I., Gahne B., Morein B., Petersson H., 1982. Immune response to some E. coli antigens in swine. Ann. Génét. Sél. anim., 14, $97-98$ (Abstr.).

Eikelendoom G., Minkema D., 1974. Prediction of pale, soft, exudative muscle with a non-lethal test for the halothane-induced porcine malignant hyperthermia syndrome. Tijdschr. Diergeneesk., 99, 421-426.

Eikelenboom G., Minkema D., Van Eldik P., Sybesma W., 1978. Production characteristics of Dutch Landrace and Dutch Yorkshire pigs as related to their susceptibility for the halothane-induced malignant hyperthermia syndrome. Livest. Prod. Sci., 5, 277-284.

Eikelenboom G., Minkema D., Van Eldik P., SYbesma W., 1980. Performance of Dutch Landrace pigs with different genotypes for the halothane-induced malignant hyperthermia syndrome. Livest. Prod. Sci., 7, 317-324.

ELY R., LEIPOLD H.W., 1979. Arthrogryposis in Yorkshire piglets. Z. Tierzücht. ZüchtBiol., 96, 241-252.

ENFIELD F.D., REMPEL W.E., 1961. Inheritance of teat number and relationship of teat number to various maternal traits in swine. J. Anim. Sci., 20, 876-879.

ENGElHARDT R., 1951. Erblichkeit und Ferkelruhr, Z. Tierzücht. ZüchtBiol., 59, 482-483.

EPSTEIN H., 1969. Domestic animals of China, Commonwealth Agricultural Bureaux, Farnham Royal, U.K.

FAHMY M.H., BERnaRd C.S., 1972. Reproductive performance of gilts from lines selected for feed utilization and carcass score. Can. J. Anim. Sci., 52, 267-271.

FAHMY M.H., BERNARD C.S., 1978. Selection for high haemoglobin level in piglets to develop an anemic-resistant line of swine. Livest. Prod. Sci., 5, 225-230.

Fahmy M.H., HoltmanN W.B., 1977. Evaluation of three- and four-breed cross litters and pigs sired by purebred and crossbred boars. Anim. Prod., 24, 261-270.

Fahmy M.H., HoltmanN W.B., Baker R.D., 1979. Failure to recycle after weaning, and weaning to oestrus interval in crossbred sows. Anim. Prod., 29, 193-202.

FALCONER D.S., 1965. The inheritance of liability to certain diseases, estimated from the incidence among relatives. Ann. hum. Genet., 29, 51-76.

FALCONER D.S., 1981. Introduction to Quantitative Genetics (2nd ed.), Longman, London.

Fass D.N., Bowie E.J.W., OWen C.A., Zollman P.E., 1979. Inheritance of porcine von Willebrand's disease : study of a kindred of over 700 pigs. Blood, 53, 712-719.

FechHeimer N.S., 1981. Cytogenetics in pig production. Pig News and Information, 2, 387-391.

FÉsüs L. Rasmusen B.A., 1971. Transferrin types and litter size in the pig. Anim. Blood Grps biochem. Genet., 2, 57.58.

FisCHER H., 1957. Inverted nipple, an inherited defect in swine. Hemera Zoa, 64, 237-238.

FISCHER H., 1960. Crooked tail, an inherited defect in swine. Hemera Zoa, 67, 33-37.

Flatla J.L., Hansen M.A., Slagsvold P., 1958. Pityriasis rosea in swine (in Norwegian). Proc. 8th Nordic Vet. Cong., 78-84.

Flatla J.L., Hansen M.A., Slagsvold P., 1961. Dermatosis vegetans in pigs. Symptomatology and genetics. Zentbl. Vet.-Med., 8, 25-42.

FLoCK D.K., 1968. Farbhelligkeit im musculus longissimus dorsi als selektionsmerkmal beim Schwein. Fleischwirtschaft, 48, 1362-1365.

FLock D.K., 1970. Genetic parameters of German Landrace pigs estimated from different relationships. J. Anim. Sci., 30, 839-843.

Förster M., Stranzinger G., Hellkuhl B., 1980. X-chromosome gene assignment of swine and cattle. Naturwissenschaften, 67, 48.

Fowler V.R., Bichard M., Pease A., 1976. Objectives in pig breeding. Anim. Prod., 23, 365-387.

FranCESCHI P.F., Ollivier L., 1981. Fréquences de quelques gènes importants dans les populations porcines. Z. Tierzücht. ZüchtBiol., 98, 176-186.

FREDEEN H.T., 1980. Pig breeding : current programs vs. future production requirements. Can. J. Anim. Sci., 60, 241-251.

Fredeen H.T., Jarmoluk L., 1963. Skeletal anomalies in swine. Can. J. Anim. Sci., 43, 143-149. 
FredeEn H.T., Newman J.A., 1962. Rib and vertebral numbers in swine. II. Genetic aspects. Can. J. Anim. Sci., 42, 240-251.

Fries R., Stranzinger G., Vögeli P., Dolf G., 1982. Provisional assignment of the G-blood group locus to chromosome $\mathbf{n}^{0} 15$ in swine. Second World Congress on Genetics applied to Livestock Production (Madrid), Symposium VI d, 10 pp. (mimeograph).

FröHLICH G., 1913. Uber die Ergebnisse experimenteller Vererbungstudien beim Schwein. $J$. Landwirt., 61, 217-235.

Frøystein T., Nøstvold S.O., Braend M., Storseth A., SChie K.A., 1981. Halothane sensitivity and blood types in the Norwegian pig breeding stock and the associations with production and meat quality traits. In : Frøystein T., Slinde E. and Standal N. (Eds), Porcine stress and meat quality: causes and possible solutions to the problems, 161-176, Agricultural Food Research Society, Ås, Norway.

FUnKQuIST H., 1929. Erblibche Begattungsunfähigkeit bei Zuchtebern. Hereditas, 13, 107-120.

GabRIS J., 1973. Genetisch bedingter Anteil and der Bildung des Blutbildes bei Ferkeln. Z. Tierzücht. Züchtbiol., 90, 41-55.

Gabris J., 1974. Die Heritabilitaet der Roten und Weissen Komponenten des Blutbildes beim Schwein. In : Ist World Congress on Genetics applied to Livestock Production., III, 1121-1124, Editorial Garsi, Madrid.

GAHNE B., 1970. The genetic control of arylesterase activity in pig serum. Anim. Blood Grps biochem. Genet., 1, 33-42.

GAHNE B., 1979. Immunogenetics and biochemical genetics as a tool in pig breeding programmes. Acta Agric. scand., Suppl. 21, 185-197.

Gahne B., 1980. Immunogenetics: a review and future prospects. Livest. Prod. Sci., 7, 1-12.

Gahne B., BengtSSON S., KLePPENES O., 1972. At least eight alleles controlling the arylesterase activity in pig serum. In : KovÁCS G. and PAPP M. (Eds), XIIth European Conference on Animal Blood Groups and Biochemical Polymorphism, 379-382. Akadémiai Kiadó, Budapest.

GAHNE B., JUNETA R.K., 1982. Genetic polymorphisms of postalbumins in pigs and close linkage with $\alpha_{1}$-protease inhibitor. In: Proceedings of the 18th International Conference on Animal Blood Groups and Biochemical Polymorphisms, Ottawa, 111 (Abstr.).

GaRnetT I., RahNefeld G.W., 1979. Factors affecting gestation length in the pig. Can. J. Anim. Sci., 59, 83-87.

GavaliER M., 1972. Relationship between blood groups and performance characters in pigs (in Czech.). Acta Zootech., Nitra, 24, 105-120.

Gavalier M., Hojný J., HradeckÝ J., Linhart J., Schröffel J., 1966. Blood groups and serum proteins in pigs. In : Polymorphismes Biochimiques des Animaux, 159-164, Institut National de la Recherche Agronomique, Paris.

Gedde-Dahl T.W., Standal N., 1970. A note on a tremor condition in adolescent pigs. Anim. Prod., 12, 665-668.

Gedymin J., Alexandrowicz S., Folejewski W., Ratajszczak M., 1964. Inheritance of TBresistance in swine. Genet. pol., 5, 57-61.

GeE D.M., NoltmanN E.A., 1981. Effect of isolation methods and of possible genetic factors on the muscle isoenzymic forms of pig muscle phosphoglucose isomerase. Comp. Biochem. Physiol., 70 B, 295-304.

Gelati K.N., Rempel W.E., Makambera T.P.E., Anderson J.F., 1973. Heterochromia irides in miniature swine. J. Hered., 64, 343-347.

Gellin J., Benne F., Hors-Cayla M.C., Gillois M., 1980. Carte génique du Porc (Sus scrofa L.). I. Etude de deux groupes synténiques G6PD, PGK, HPRT et PKM2, MPI. Ann. Génét., 23, 15-21.

Gellin J., Echard G., BenNe F., Gillois M., 1981. Pig gene mapping : PKM2-MPI-NP synteny. Cytogenet. Cell Genet., 30, 59-62.

GerRits R.J., KRaeling R.R., KinCaid C.M., 1969. Polymorphism in a casein fraction of sow's milk. Biochem. Genet., 3, 355-358.

Gibbons R.A., Sellwood R., Burrows M., Hunter P.A., 1977. Inheritance of resistance to neonatal E. Coli diarrhoea in the pig: examination of the genetic system. Theor. Appl. Genet., 51, 65-70. 
Gibson E.A., Blackmore R.J.J., Wijeratne W.V.S., Wrathall A.E., 1976. The "barker» (neonatal respiratory distress) syndrome in the pig: its occurrence in the field. Vet. Rec., 98, 476-479.

Gilman J.P.W., 1956. Congenital hydrocephalus in domestic animals. Cornell Vet., 46, 487-499.

GlasNák V., 1966. Protein polymorphism in sow's milk. In : Polymorphismes Biochimiques des Animaux, 433-435, Institut National de la Recherche Agronomique, Paris.

Glasnák V., 1968 a. Polymorphism of $\beta_{1}$-caseins in sow's milk. Folia biol., Praha, 14, 70-73.

GLASNÁK V., 1968 b. Inter- and intraspecific differences in milk proteins of cattle and swine. Comp. Biochem. Physiol., 25, 355-357.

Glasnák V., Stratil A., Schleger W., 1976. A transferrin variant Tf 1 in crosses of the wild and domestic pigs. Anim. Blood Groups biochem. Genet., 7, 59-64.

Glawischnig E., Swoboda R., Schlecht H., 1974. Zum Vorkommen der Dermatosis Vegetans des Schweines in Osterreich. Dt. tierärztl. Wschr., 81, 5-9.

Gligor V., IORDANESCU I., Frum M., 1959. $\mathrm{F}_{1}$ Large Black $\times$ Large White crossbreds (in Rumanian). Lucr. stiint. Inst. Cerc. zooteh., 17, 227-242.

Gligor V., IORDANESCU I., Frum M., 1960. Morpho-productive characters of $F_{2}$ crossbreds compared with $\mathrm{F}_{1}$ from Large Black and Large White crosses (in Rumanian). Lucr. stiint. Inst. Cerc. zooteh., 18, 395-409.

GlodeK P., 1982. Selection responses in pigs : results and implications. In : 2nd World Congress on Genetics applied to Livestock Production, V, 568-577, Editorial Garsi, Madrid.

Gluhovschi N., Bistriceanu M., Calangui M., Bratu M., 1969. Les dysgénésies gonadales chez les porcins. Recl Méd. vét. Ec. Alfort, 145, 1127-1140.

Gluhovschi N., Bistriceanu M., Nafornita M., Iusco V., Bratu M., 1967. Identification d'une anomalie héréditaire chez les porcins caractérisée par l'abréviation de la colonne vertébrale et la réduction du nombre des vertèbres. Recl Méd. vét. Ec. Alfort, 143, 827-839.

Griggs T.R., Webster W.P., CoOper H.A., Wagner R.H., Brinkhous K.M., 1974. Von Willebrand factor : gene dosage relationships and transfusion response in bleeder swine - a new bioassay. Proc. natn. Acad. Sci. U.S.A., 71, 2087-2090.

GRÖNDALEN T., 1974. Leg weakness in pigs. II. Litter differences in leg weakness, skeletal lesions, joint shape and exterior conformation. Acta vet. scand., 15, 574-586.

Gruhn R.. DinkLaGE H., 1971. Blutgruppen- und proteinpolymorphismus beim Göttinger miniaturschwein. Z. Versuchst., 13, 179-187.

GRUnder A.A., KRISTJAnSSON F.K., 1974. Genetic control of serum esterases in day-old pigs. Anim. Blood Grps. biochem. Genet., 5, 143-151.

Guérin G., Ollivier L., Sellier P., 1978. Déséquilibres de linkage entre les locus Hal (Hyperthermie maligne), PHI et 6-PGD dans deux lignées Piétrain. Ann. Génét. Sél. anim., 10, 125-129.

Guérin G., Ollivier L., Sellier P., 1979. Effet d'entraînement d'un gène sélectionné et association gamétique (déséquilibre de "linkage ") : l'exemple de deux locus étroitement liés chez le porc, Hal (sensibilité à l'halothane) et PHI (phosphohexose isomérase). $C$. $R$. hebd. séances Acad. Sci., Paris, 289, 153-156.

Guérin G., Ollivier L., Sellier P., 1980. Fréquences géniques et déséquilibres de "linkage " aux locus Hal, PHI et 6-PGD dans quelques races porcines françaises (résultats préliminaires). Ann. Génét. Sél. anim., 12, 407 (Abstr.).

Guérin G., Ollivier L., Sellier P., 1983. Etude du groupe de liaison Hal, Phi et Pgd chez le porc. Disposition relative des trois locus et estimation des taux de recombinaison. Génét. Sél. Evol., 15 (sous presse).

GUSTAvSSON I., 1980. Chromosome aberrations and their influence on the reproductive performance of domestic animals. A review. Z. Tierzücht. Züchtbiol., 97, 176-195.

Hagen K.L., Rasmusen B.A., 1974. Segregation and sex ratios in the B blood-group system in pigs. Genetics, 77, s28 (Abstr.).

Hagen K.L., Rasmusen B.A., Mittal K.K., 1968. Further investigations on linkage between the loci for heme-binding globulins and $\mathrm{K}$ blood groups in pigs. Vox Sang., 15, 147-151.

HÁLA K., 1967. Occurrence of erythrocyte antigens on cells from various tissues of the pig. Folia biol., Praha, 13, 189-192. 
HÁla K., HojnÝ J., 1964. Blood groups of the N system in pigs. Folia biol., Praha, 10, 239-244.

Hall L.W., WoOlF N., Bradley J.W.P., Jolly D.W., 1966. Unusual reaction to suxamethonium chloride. Br. med. J., 2, 1305.

Hallovist C., 1933. Ein Fall von letalfaktoren beim Schwein. Hereditas, 18, 215-224.

HAMORI D., 1962 a. Kraterförmige Zitzen bei Sauen. Zuchthyg. FortpflStör. Besam. Haustiere, 6, 91-94.

HAMORI D., 1962 b. Uber die Anlage für Brüche bei Schweinen. Zuchthyg. FortpflStör. Besam. Haustiere, 6, 80-84.

HAMORI D., 1965. Vererbung des Fehlens des Anus-Sphinkter bei Ferkeln. Fortpfl. Besam. Haustiere, 1, 129-132.

HANCOCK J., 1950. Lethal and other inherited factors causing abnormalities in New Zealand stock. Proc. N. Z. Soc. Anim. Prod. 10th Ann. Conf. 1950, 91-104.

HANCOCK J.L., DAKER M.G., 1981. Testicular hypoplasia in a boar with abnormal sex chromosome constitution (39 XXY). J. Reprod. Fert., 61, 395-397.

Hanly S., 1961. Prenatal mortality in farm animals. J. Reprod. Fert., 2, 182-194.

HANSEN K.M., 1980. The relative length of pig chromosomes, and a suggestion for a karyotype system. Ann. Génét. Sél. anim., 12, 313-320.

Hansen-Melander E., Melander Y., 1974. The karyotype of the pig. Hereditas, 77, 149-157.

HANSET R., 1959. Un aperçu de la génétique des robes chez le porc. Ann. Méd. vét., 103, 53-66.

Hanset R., Camerlynck R., 1974. L'héritabilité du nombre de mamelles chez le porc Piétrain et le porc Landrace Belge. Ann. Génét. Sél. anim., 6, 91-102.

HANSET R., VAN SNick G., 1972. Les paramètres génétiques des caractères d'engraissement et de carcasse chez le porc de Piétrain. Ann. Génét. Sél. anim., 4, 451-467.

HANSET R., VAN SNICK G., 1973. Les paramètres génétiques des caractères d'engraissement et de carcasse chez le porc Landrace Belge. Ann. Génét. Sél. anim., 5, 369-379.

Harding J.D.J., Done J.T., Harbourne J.F., Randall C.J., Gilbert F.R., 1973. Congenital tremor type A III in pigs : an hereditary sex-linked cerebrospinal hypomyelinogenesis. Vet. Rec., 92, 527-529.

HARMEYER J., 1982. Inherited disturbance of vitamin D metabolism in pigs. In : 2nd World Congress on Genetics applied to Livestock Production, VII, 64-75, Editorial Garsi, Madrid.

Heidenreich C.J., Garwood V.A., Harrington R.B., 1964. Swine growth and composition as associated with total serum cholesterol. J. Anim. Sci., 23, 496-498.

HENRICSON B., BACKSTRÖM L., 1964. Translocation heterozygosity in a boar. Hereditas, 52, $166-170$.

HENRY Y., 1977. Développement morphologique et métabolique du tissu adipeux chez le porc: influence de la sélection, de l'alimentation et du mode d'élevage. Ann. Biol. anim. Biochim. Biophys., 17, 923-952.

Hesselholt M., 1970. Additional studies into serum amylase in swine. In: XIth European Conference on Animal Blood Groups and Biochemical Polymorphism, 347-353, Polish Scientific Publishers, Warsaw.

Hesselholt M., Hristic V., 1966. Haemopexin polymorphism in pigs. Acta vet. scand., 7 , 187-188.

Hesselholt M., Nielsen P.B., 1966. Studies on the genetic relationship between the haemopexin system and other blood group systems in pigs. In : Polymorphismes Biochimiques des Animaux, 445-448, Institut National de la Recherche Agronomique, Paris.

HETZER H.O., 1945 a. Inheritance of coat color in swine. I. General survey of major color variations in swine. J. Hered., 36, 121-128.

HETZER H.O., 1945 b. Inheritance of coat color in swine. II. Results of Landrace by Poland China crosses. J. Hered., 36, 187-192.

HETZER H.O., 1945 c. Inheritance of coat color in swine. III. Results of Landrace by Berkshire crosses. J. Hered., 36, 255-256. 
HetZer H.O., 1945 d. Inheritance of coat color in swine. IV. Analysis of hybrids of Landrace and Large Black. J. Hered., 36, 309-312.

HETZER H.O., 1946. Inheritance of coat color in swine. V. Results of Landrace by DurocJersey crosses. J. Hered., 37, 217-224.

HeTZER H.O., 1947. Inheritance of coat color in swine. VI. Results of Yorkshire by DurocJersey crosses. J. Hered., 38, 121-124.

HETZER H.O., 1948. Inheritance of coat color in swine. VII. Results of Landrace by Hampshire crosses. J. Hered., 39, 123-128.

HETZER H.O., 1954. Effectiveness of selection for extension of black-spotting in Beltsville $n^{0} 1$ swine. J. Hered., 45, 215-223.

Heuner F., 1957. Weitere Beobachtungen über das Auftreten der Bauchflechte (Pityriasis rosea) der Ferkel. Tierärztl. Umsch., 12, 354-355.

Himeno K., Nagano R., Mogi K., Abe T., Hosoda T., 1969. Studies on haemolytic disease of new-born piglets. VII. Genetic study on the red cell antigen involved in haemolytic disease (in Japanese). Jap. J. zootech. Sci., 40, 212-219.

HOJNÝ J., 1973. Further contribution to the $\mathrm{H}$ blood system in pigs. Anim. Blood Grps biochem. Genet., 4, 161-168.

HOJNÝ J., 1974. $\mathrm{H}$ blood group genotypes and expression of $\mathrm{A}$ and $\mathrm{O}$ antigens in pigs. Anim. Blood Grps biochem. Genet., 5, 3-10.

HoJnÝ J., Duniec M., 1980. Genetic studies of allotypes in pigs. Anim. Blood Grps biochem. Genet., 11 (suppl. 1), 60 (Abstr.).

Hojný J., Gavalier M., Hradecký J., Linhart J., 1966. New blood factors in pigs. In Polymorphismes Biochimiques des Animaux, 151-158, Institut National de la Recherche Agronomique, Paris.

HOJNÝ J., HÁla K., 1965 a. A contribution to the study of the blood group system A in pigs. In : Matoušek J. (Ed.), Blood Groups of Animals, 155-161, Publishing House of the Czechoslovak Academy of Sciences, Prague.

HojnÝ J., Hála K., 1965 b. Blood group system O in pigs. In : MatoušEK J. (Ed.), Blood Groups of Animals, 163-168, Publishing House of the Czechoslovak Academy of Sciences, Prague.

HoJnÝ J., HRadeckÝ J., 1972. A contribution to the study on $\mathrm{H}, \mathrm{J}$ and $\mathbf{M}$ blood group systems in pigs. In : KovÁCS G. and PAPP M. (Eds), XIIth European Conference on Animal Blood Groups and Biochemical Polymorphism, 299-303, Akadémiai Kiadó, Budapest.

HojnÝ J., HradeckÝ J., Camacho A., 1979 a. Further factors and alleles of the M blood groups system in pigs. In : Pavlichenko V.P. (Ed.), Proceedings of the XVIth International Conference on Animal Blood Groups and Biochemical Polymorphism, III, 114-120.

Hojný J., Hradecký J., Pazdera J., 1979 b. The blood group factor Kf and allele $K^{a e}$ in the pig. Anim. Blood Grps biochem. Genet., 10, 175-180.

HOJNÝ J., Stratil A., 1978. Report on the pig and sheep blood group and polymorphic protein workshops (Liběchov, 9 to 11 August 1978). Anim. Blood Grps biochem. Genet., 9, 245-251.

Hojný J., Valenta M., Cepica S., Hruban V., Hradecký J., 1979 c. The relationship between halothane sensitivity and blood group systems in pigs. Acta Agric. scand., suppl. 21, 463-468.

HolmQvist L., 1971. Inverted teats (in Swedish). Svinskötsel, 61, 7-11.

HoLST S.J., 1949. Sterility in boars. Nord. Vet.-Med., 1, 87-120.

Holz K., FortuIN V., 1956. Multiple Missbildungen bei einem Schwein. Dt. tierärztl. Wschr., 63, 339-342.

Hook R.R. Jr., Aultman M.D., Adelstein E.H., Oxenhandler R.W., Millikan L.E., MIDDLETON C.C., 1979. Influence of selective breeding on the incidence of melanomas in Sinclair miniature swine. Int. J. Cancer, 24, 668-672.

HORNEFF W., 1967. Das Auftreten von Schrumpfohren beim Schwein. Schweinezucht Schweinemast, 15, 231-232.

HRADECKÝ J., HoJnÝ J., 1970. Blood factor Fb in pigs. Anim. Blood Grps biochem. Genet., 1, $125-126$.

Hradecký J., Hruban V., Pazdera J., Klaudy J., 1980. Inheritance of sensitivity to halothane in pigs. Züchthygiene, 15, 219-225. 
Hradecký J., Hruban V., Pazdera J., Klaudy J., 1982. Map arrangement of the Sla chromosomal region and the $\mathbf{J}$ and $\mathrm{C}$ blood group loci in the pig. Anim. Blood Grps biochem. Genet., 13, 223-224.

HRadecký J., Linhart J., 1970. Db, next blood factor of the D system in pigs. Anim. Blood Grps biochem. Genet., 1, 65-66.

HRUBAN V., 1981. Immunogenetics of pigs with partial reference to the major histocompatibility complex. In : LundSTRÖM K., GAHNE B., EDFORS-LILJA I. (Eds), Immunogenetics in Animal Breeding, Report 47, 70-83, The Swedish University of Agricultural Sciences, Uppsala, Sweden.

Hruban V., Hradecký J., Pazdera J., Simon M., Veselský L., 1978. SlB, a new alloantigenic system of the pig. J. Immunogenetics, 5, 173-178.

Hruban V., Simon M., HŔadeckÝ J., 1972. Alloantigens common to erythrocytes and leucocytes in pigs. Anim. Blood Grps biochem. Genet., 3, 157-161.

Hruban V., Simon M., HradeckÝ J., 1974. Histocompatibility studies in pigs from outbred and semi-inbred families. Anim. Blood Grps biochem. Genet., 5, 171-176.

Hruban V., Simon M., HradeckÝ J., Jílek F., 1976. Linkage of the pig main histocompatibility complex and the $\mathrm{J}$ blood group system. Tissue Antigens, 7, 267-271.

Hruban V., Simon M., Hradecký J., Pazdera J., 1977. Serologically defined specificities of the pig main histocompatibility complex (SL-A), Anim. Blood Grps biochem. Genet., 8, 85-92.

HUANG J.Y., 1978. Quantitative inheritance of immunological response in swine. Diss. Abstr., 38, 4057-B.

Huang M.Y., Rasmusen B.A., 1982. Parental transferrin types and litter size in pigs. J. Anim. Sci., 54, 757-762.

HUhN U., 1970. Hoden- und Samencharakteristika männlicher Schweine in Abhängigkeit von Jungendentwicklung und Vererbung. Fortpfl. Besam. Haustiere, 6, 350-364.

Hulot F., 1969. Les chromosomes des suiformes. Ann. Génét. Sél. anim., 1, 315-336.

Huston R., Saperstein G., Schoneweis D., Leipold H.W., 1978. Congenital defects in pigs. Vet. Bull., 48, 645-675.

HUTCHENS L.K., HiNTZ R.L., JOHNSON R.K., 1981. Genetic and phenotypic relationships between pubertal and growth characteristics of gilts. J. Anim. Sci., 53, 946-951.

HyldgaARD-Jensen J., 1978. Adenosine deaminase and disease resistance in pigs (in Danish). Aarsberetn. Inst. Sterelitetsforsk. 1978, 49-56.

HyldgaARD-Jensen J., 1979. Immune response in pigs. 1. - Genetic variations in specific antibody production and serum total immunoglobin (in Danish). Aarsberetn. Inst. Sterelitetsforsk. 1979, 99-112.

HYLDGAARD-JENSEN J., 1980. The glutathione content in pig blood (in Danish). Aarsberetn. Inst. Sterelitetsforsk. 1980, 61-68.

HYLDGaARD-JEnSEN J., 1981. Adenosine deaminase polymorphism in pig leucocytes (in Danish). Aarsberetn. Inst. Sterelitetsforsk. 1981, 103-109.

HYLDGAARD-JENSEN J., JøRGENSEN P.F., 1978. Serum protein and enzyme type polymorphism in pigs (in Danish). Aarsberetn. Inst. Sterelitetsforsk. 1978, 85-100.

HyLDGAARD-JEnSEN J., ThORUP I., 1981. Esterase D polymorphism in Danish Landrace pigs (in Danish). Aarsberetn. Inst. Sterelitetsforsk. 1981, 110-117.

HyldgaARd-JenSEn J., Wegger I., 1977. Adenosine deaminase in pigs. II. - Qualitative and quantitative genetic variation (in Danish). Aarsberetn. Inst. Sterelitetsforsk. 1977, 131-139.

IDVALL S., 1952. A striking instance of abnormalities in the Large White breed (in Swedish). Svenska Svinavelsför. Tidskr., 4, 67-70.

IMLAH P., 1964. Inherited variants in serum ceruloplasmins of the pig. Nature, Lond., 203, 658-659.

IMLAH P., 1965. A study of blood groups in pigs. In : MATOUŠEK J. (Ed.), Blood Groups of Animals, 109-122, Publishing House of the Czechoslovak Academy of Sciences, Prague.

IMLAH P., 1970 a. Evidence for the Tf locus being associated with an early lethal factor in a strain of pigs. Anim. Blood Grps biochem. Genet., 1, 5-13. 
IMLAH P., $1970 \mathrm{~b}$. Ontogenic and familial variation in serum alkaline phosphatase of pigs. In : XIth European Conference on Animal Blood Groups and Biochemical Polymorphism, 331-338, Polish Scientific Publishers, Warsaw.

IMLAH P., 1972 a. The fourth comparison test of pig blood groups. In : Kovács G. and PAPP M. (Eds), XIIth European Conference on Animal Blood Groups and Biochemical Polymorphism, 409-410, Akadémiai Kiadó, Budapest.

IMLAH P., 1972 b. Application of blood group loci in studies on pre-natal and post-natal survival of piglets. Anim. Blood Grps biochem. Genet., 3 (suppl. 1), 80 (Abstr.).

IMLAH P., 1980. Linkage studies on the A-O, H and Gpi loci and the Hal (halothane) locus in pigs. Anim. Blood Grps biochem. Genet., 11 (suppl. 1), 47 (Abstr.).

ImL.AH P., Thomson S.R.M., 1979. The H blood group locus and meat colour, and using blood groups to predict halothane reactors. Acta Agric. scand., suppl. 21, 403-410.

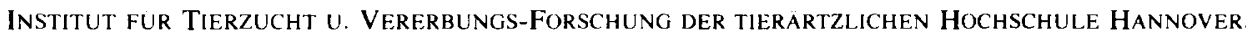
1975. Hinterschenkelatrophie beim Schwein : ein Zuchtexperiment. Dt. Tierärztl. Wschr., 82, 33.

IVANYI P., 1977. The major histocompatibility system of pig. In : GötZE D. (Ed.), The Major Histocompatibility System in Man and Animals, 168-174, Springer-Verlag, Berlin.

Jensen E.L., Smith C., Baker L.N., Cox D.F., 1968. Quantitative studies on blood group and serum protein systems in pigs. II. - Effects on production and reproduction. J. Anim. Sci., 27, 856-862.

JENSEN P., 1981. Carcass and meat quality of pigs with known genotypes for halothane susceptibility. In : Frøystein T., SLINDE E. and STANDal N. (Eds), Porcine stress and meat quality : causes and possible solutions to the problems, 267-273, Agricultural Food Research Society, As, Norway.

JENSEN P., ANDRESEN E., 1980. Testing methods for PSE syndrome : current research in Denmark. Livest. Prod. Sci., 7, 325-335.

Jensen P., Craig H.B., Robison O.W., 1967. Phenotypic and genetic associations among carcass traits of swine. J. Anim. Sci., 26, 1252-1260.

JERICHO K.W.F., 1974. Dermatosis vegetans- giant cell pneumonitis in pigs : further observations and interpretations. Res. vet. Sci., 16, 176-181.

JOHANSSON I., 1964. Hereditary defects in pigs (in Swedish). LantbrHögsk. Meddn, 14.

JOHANSSON I., KORKMAN N., 1950. A study of the variation in production traits of bacon pigs. Acta Agric. scand., 1, 62-96.

JOHANSSON K., 1981. Some notes concerning the genetic possibilities of improving sow fertility. Livest. Prod. Sci., 8, 43!-447.

JOHANSSON K., KENNEDY B.W., 1982. Estimation of genetic parameters of fertility traits in pigs. In : 2nd World Congress on Genetics applied to Livestock Production, VII, 503-508, Editorial Garsi, Madrid.

JOHNSON D.H., LUSH J.L., 1939. "Legless », a new lethal in swine. Genetics, 24, 79.

JOHNSON R.K., 1981. Crossbreeding in swine: experimental results. J. Anim. Sci., 52, 906-923.

JOHNSON R.K., OMTVEDT I.T., WALTERS L.E., 1978. Comparison of productivity and performance for two-breed and three-breed crosses in swine. J. Anim. Sci., 46, 69-82.

JONSSON P., 1963. Danish pig progeny testing results. Z. Tierzücht. ZüchtBiol., 78, 205-252.

JONSSON P., 1965. Analysis of characters in the Danish Landrace pig with a historical introduction (in Danish). 350. beretning fra forsogslaboratoriet, Copenhagen.

JONSSON P., 1974. Applied aspects of pig selection. In : Ist World Congress on Genetics applied to Livestock Production, I, 837-847, Editorial Garsi, Madrid.

JONSSON P., 1975. Methods of pig improvement through breeding in European countries : a review. Livest. Prod. Sci., 2, 1-28.

JONSSON P., ANDRESEN $\emptyset$., 1979. Experience during two generations of within lines boar performance testing, using $5 \alpha$-androst-16-ene-3-one ( $5 \alpha$-androstenone) and an olfactory judgement of boar taint. Ann. Génét. Sél. anim., 11, 241-250.

Jonsson P., JENSEN P., PEDersen O.K., 1972. Genetic aspects of meat quality in pigs. Ann. Génét. Sél. anim., 4, 99-116. 
Jonsson P., Wismer-Pedersen J., 1974. Genetics of sex odour in boars. Livest. Prod. Sci., 1, 53-66.

JøRGENSEN P.F., 1978. Halothane sensitivity, the $H$ blood group system and phosphohexose isomerase (PHI) in pigs. A linkage study of physiological importance. Acta vet. scand., 19, 458-460.

JøRGensen P.F., 1979. Polymorphic systems in blood. Associations with porcine halothane sensitivity and meat quality. Acta Agric. scand., suppl. 21, 386-395.

JøRGENSEN P.F., 1981. Blood types and other biochemical markers for stress-susceptibility and meat quality in pigs. In : Frøystein T., Slinde E. and Standal N. (Eds), Porcine stress and meat quality: causes and possible solutions to the problems, 146-159, Agricultural Food Research Society, Ås, Norway.

Jørgensen P.F., Hyldgaard-Jensen J., 1981. Blood parameters and meat quality. Pig News and Information, 2, 9-15.

Jørgensen P.F., Hyldgaard-Jensen J., Moustgaard J., 1977. Glutathione peroxidase activity in porcine blood. Acta vet. scand., 18, 323-334.

Jørgensen P.F., Hyldgaard-Jensen J., Moustgaard J., Eikelenboom G., 1976. Phosphohexose isomerase (PHI) and porcine halothane sensitivity. Acta vet. scand., 17, 370-372.

JøRGENSEN S.K., 1959. Congenital porphyria in pigs. Br. vet. J., 115, 160-175.

Jumkov V.A., Nikonchik L.I., 1977. Serum amylase-2 polymorphism in pigs. Anim. Blood Grps biochem. Genet., 8, 247-250.

Juneja R.K., GahNe B., 1978. Post albumin variants in pig plasma detected by polyacrylamide gel electrophoresis. Ann. Génét. Sél. anim., 10, 603 (Abstr.).

Juneja R.K., Gahne B., 1981. Polymorphic serum prealbumin $(\mathrm{Pa})$ of pig, identified as an $\alpha_{1}$-protease inhibitor. Anim. Blood Grps biochem. Genet., 12, 47-51.

Juneja R.K., Gahne B., Edfors-Lilja I., ANdresen E., 1982. Genetic variation at a pig serum protein locus, Po-2, and its assignment to the Phi, Hal, S, H, Pgd linkage group. Anim. Blood Grps biochem. Genet., 13, in press.

KaempFFer A., 1932. Uber die Vererbung der Blutgruppen des Schweines. Z. indukt. Abstamm. u. VererbLehre, 61, 261-300.

Kawecki A.M., Klemke A., Przytul.skı T., 1974. Polymorphism of prealbumins, transferrins in blood serum of pigs of Polish Large White breed. Theor. Appl. Genet., 45, 59-63.

Keller K., 1941. Verschiedenartige Missbildungen in einem Wurf beim Schwein. Wien. tierärztl. Mschr., 28, 177-182.

Kellogg T.F.. Rogers R.W., Mil.l.er H.W., 1977. Differences in tissue fatty acids and cholesterol of swine from different genetic backgrounds. J. Anim. Sci., 44, 47-52.

Kemmer B., 1969. $\beta$-Laktoglobulin-Typen in der Sauenmilch. Züchtungskunde, 41, 331-334.

Kemmer B., Gruhn R., Dinklage H., 1972. Studies on protein polymorphism in sow's milk. In : KovÁCS G. and PAPP M. (Eds), XIIth European Conference on Animal Blood Groups and Biochemical Polymorphism, 393-396, Akadémiai Kiadó, Budapest.

KenNedy B.W., Johansson K., SchatFFer L.R., 1982. Heritabilities and genetic correlations for growth rate and backfat in performance tested pigs. In : Proc. Ann. Meet. Amer. Soc. Anim. Sci. Can. Soc. Anim. Sci., August 8-11, 1982, Guelph, $151-152$ (Abstr.).

KENNEDY B.W., MOXLEY J.E., 1980. Genetic factors influencing atrophic rhinitis in the pig. Anim. Prod., 30, 277-283.

KENNEdY B.W., Moxl.ey J.E., SAISON R., 1973. Some relationships between blood group factors and economic traits in swine. Can. J. Anim. Sci., 53, 389-397.

Kierek-Jaszcuk D., Zurkowski M., Skladanowska-Krzyzanowska E., Tomaszewska-GuszkieWICZ K.. 1978. Serum alkaline phosphatase polymorphism in pigs. Anim. Blood Grps biochem. Genet., 9, 15-18.

KING J.W.B., RoBERTS R.C., 1959. The effects of inbreeding on carcass traits in the bacon pig. Anim. Prod., 1, 123-127.

KING W.A., Linares T., 1980. Three cases of segmental aplasia of the uterus in inbred gilts. Acta vet. scand., 21, 149-152.

Kintaba N.K., Hanset R., Leroy P., Michaux C., 1981. Paramètres génétiques des caractères d'engraissement et de carcasse chez le porc de Piétrain et le porc Landrace Belge. Ann. Méd. vét., 125, 123-142. 
Kloster G., Larsen B., Nielsen P.B., 1970. Carbonic anhydrase polymorphism in cattle and swine. Acta vet. scand., 11, 318-321.

KLUCINSKI W., 1973. Current views on the polymorphism of proteins and enzymes in pig blood (in Polish). Postepy Biochem., 19, 123-140.

Косh P., Fischer H., Schumann H., 1957. Erbpathologie der Landwirtschaftlichen Haustiere, Paul Parey, Berlin and Hamburg.

KöNiG H., Weber W., KupfersChmied H., 1972. Zur Nebenhodenaplasie beim Stier und Eber. (a) Darstellung von 18 Fallen mit rezessivem Erbgang beim Simmentaler Fleckvieh. (b) Auftreten der Anomalie bei einem Eber und drei Sohnen. Schweizer Arch. Tierheilk., 114, 73-82.

Kosswig C., Ossent H.P., 1931. Die Vererbung der Haarfarben beim Schwein. Z. Zücht. B, 22, 297-381.

Kosswig C., Ossent H.P., 1932. Ein Beitrag zur Vererbung der Haarfarben beim Schwein. Züchter, 4, 225-230.

Kosswig C., OSsent H.P., 1934. Weitere Ergebnisse über die Vererbung der Haarfarben beim Schwein. Züchter, 6, 306-308.

Kraeling R.R., Gerrits R.J., 1969. Polymorphism of a protein of sow's whey. J. Dairy Sci., 52, 2036-2038.

Kraeling R.R., GerRITS R.J., YOUNG E.P., 1971. Transferrin and pre-albumin polymorphisms in swine selected for backfat thickness. J. Anim. Sci., 32, 174-178.

KRISTENSEN B., Wäfler P., DE WECK A.L., 1980. Histocompatibility antigens (SLA) in swine. Possible correlation between SLA haplotypes and performances of piglets. Anim. Blood Grps biochem. Genet., 11 (suppl. 1), 58-59 (Abstr.).

KRISTJANSSON F.K., 1960 a. Inheritance of a serum protein in swine. Science, 131, 1681.

KRISTJANSSON F.K., 1960 b. Genetic control of two blood serum proteins in swine. Can. J. Genet. Cytol., 2, 295-300.

Kristjansson F.K., 1961. Genetic control of three haptoglobins in pigs. Genetics, 46, 907-910.

KRISTJANSSON F.K., 1963. Genetic control of two pre-albumins in pigs. Genetics, 48, 1059-1063.

KRISTJANSSON F.K., 1964. Transferrin types and reproductive performance in the pig. J. Reprod. Fert., 8, 311-317.

KRISTJANSSON F.K., 1966. Fractionation of serum albumin and genetic control of two albumin fractions in pigs. Genetics, 53, 675-679.

KRONACHER C., 1924. Vererbungsversuche und Beobachtungen an Schweinen. Z. indukt. Abstamm. - $u$. VererbLehre, 34, 1-120.

KRONACHER C., OGRIZEK A., 1932. Vererbungsversuche und Beobachtungen an Schweinen. Z. Zücht. B, 25, 3-43.

Kruger G., 1965. Agnathia inferior bei Ferkeln. Tierärztl. Umsch., 20, 32.

KUвEK A., 1970. Electrophoretical study of the esterases in pigs serum. In : XIth European Conference on Animal Blood Groups and Biochemical Polymorphism, 355-358, Polish Scientific Publishers, Warsaw.

Kubek A., Dinklage H., 1971. Phosphohexose isomerase polymorphism of pigs. Anim. Blood Grps biochem. Genet., 2, 35-38.

Kubek A., Matouśek J., 1970. Polymorphism of postalbumins in the serum of pigs and the ovarian follicle fluids of sows. Anim. Blood Grps biochem. Genet., 1, 163-167.

Kurosawa Y., Oishi T., Tanaka K., Suzuki S., 1979. Immunogenetic studies on wild pigs in Japan. Anim. Blood Grps biochem. Genet., 10, 227-233.

Kuzmenko L.G., 1968 a. Genetic polymorphism of transferrins in connection with fertility in pigs (in Russian). Tsitol. Genet., 2, 270-273.

KUZMENKo L.G., 1968 b. Fertilizing capacity in pigs depending on their matings in homo- and heterozygous combinations of transferrin types (in Russian). Tsitol. Genet., 2, 469-471.

LABIK K., 1972. Hereditarily conditioned anomalies of the facial part of the animal head. Acta vet., Brno, 41, 167-176.

LAMPO P., 1980. La sensibilité au stress étudiée au moyen d'enzymes du sérum sanguin chez le porc Landrace belge. 1. - Paramètres phénotypiques et génétiques. Revue Agric., Brux., 33, 225-234. 
Lampo P., 1981 a. La sensibilité au stress chez le Landrace belge. Corrélation entre le test à l'halothane et le test des enzymes du sérum sanguin. Revue Agric., Brux., 34, 205-211.

LAMPO P., 1981 b. La sensibilité au stress chez le Landrace belge. La relation entre le test d'anesthésie à l'halothane, les caractéristiques d'engraissement et de carcasse. Revue Agric., Brux., 34, 213-220.

LANG B.G., 1970. Globulin allotyping in pigs using iso-precipitins. In : XIth European Conference on Animal Blood Groups and Biochemical Polymorphism, 301-306, Polish Scientific Publishers, Warsaw.

LANGHOLZ H.J., 1966. Das züchterische Hilfsmittel der stationären Nachkommenprüfung beim Schwein. III. - Heritabilitäten und genetische Korrelationen beim norwegischen Landschwein. Acta Agric. scand., 16, 97-114.

LARSEN B., 1971. Blood groups and polymorphic proteins in cattle and swine. Ann Génét. Sél. anim., 3, 59-70.

LARSSON E.L., 1953. "Club-footed » pigs. Svenska Svinavelsför. Tidskr., 1, 7-21.

LARSSON E.L., 1961. Ringworm ("belly scurf") in piglets (in Swedish). Svenska Svinavelsför. Tidskr., 11, 212-221.

Lauvergne J.J., CanOPE I., 1979. Etude de quelques variants colorés du porc Créole de la Guadeloupe. Ann. Génét. Sél. anim., 11, 381-390.

Lauvergne J.J., Malynicz G.L., Quartermain A.R., 1982. Coat colour variants of village pigs in Papua New Guinea. Ann. Génét. Sél. anim., 14, 29-42.

LAUVergne J.J., Ollivier L., 1966. A propos de colorations observées lors de croisements entre porcs de Piétrain et porcs Large White. Ann. Génét., 9, 39-41.

LAX T., 1971. Hereditary splayleg in pigs. J. Hered., 62, 250-251.

Legault C., 1970. Etude statistique et génétique des performances d'élevage des truies de race Large White. II. - Effet direct du verrat, héritabilité, répétabilité, corrélations. Ann. Génét. Sél. anim., 2, 209-227.

Legault C., Aumaitre A., du Mesnil du Buisson F., 1975. The improvement of sow productivity, a review of recent experiments in France. Livest. Prod. Sci., 2, 235-246.

Legault C., Gruand J., 1981. Effets additifs et non additifs des gènes sur la précocité sexuelle, le taux d'ovulation et la mortalité embryonnaire chez la jeune truie. In : Journées de la Recherche Porcine en France 1981, 247-254, Institut Technique du Porc, Paris.

Legault C., Gruand J., Oulion F., 1979. Mise au point et intérêt génétique d'une méthode d'appréciation sur le vivant du poids des testicules chez le jeune verrat. In:Journées de la Recherche Porcine en France 1979, 313-322, Institut Technique du Porc, Paris.

Legault C., Ollivier L., 1974. Plans de sélection porcine. In : Ist World Congress on Genetics applied to Livestock Production, I, 823-835, Editorial Garsi, Madrid.

Lengerken G., Pfeiffer H., 1974. Der Transferrinpolymorphismus im Blutserum beim Schwein und dessen Beziehung zu Merkmalen der Mastleistung und Schlachtkörperqualität. Arch. Tierz., 17, 345-354.

LEONG M.M., LiN C.C., RUTH R.F., 1982 a. The localization of HPRT, G6PD and GLA on the $\mathrm{X}$ chromosome of the domestic pig. Cytogenet. Cell Genet. (Human Gene Mapping 6), 32, 295 (Abstr.).

LEONG M.M., LIN C.C., RUTH R.F., 1982 b. Assignment of superoxide dismutase (SODI) gene to pig chromosome 9. Cytogenet. Cell Genet. (Human Gene Mapping 6), 32, 294 (Abstr.).

Leveziel H., 1979. Le complexe d'histocompatibilité majeur chez l'homme et chez les animaux. Ann. Génét. Sél. anim., 11, 281-356.

Leymaster K.A., Swiger L.A., 1981. Selection for increased leanness of Yorkshire swine. III. - Inbreeding effects on secondary traits. J. Anim. Sci., 53, 620-628.

Lin C.C., Biederman B.M., Jamro H.K., Hawthorne A.B., Church R.B., 1980. Porcine (Sus scrofa domestica) chromosome identification and suggested nomenclature. Can. J. Genet. Cytol., 22, 103-116.

LinharT J., 1971. Lm, a new blood group factor of the L system in pigs. Anim. Blood Grps biochem. Genet., 2, 243-245.

LinhaRT J., Romanov J.D., 1975. Eabgmnop $\left(=E^{15}\right)$, a new allele in the E blood-group system of the pig. Anim. Blood Grps biochem. Genet., 6, 57-59. 
Locniskar F.. Pen A., Salehar A., Urbas J., Zagozen F., 1975. Alkaline phosphatase activity as a selection criterion in pigs (in Serbo-croat). Stocarstvo, 29, 15-23.

LOJDA L., 1975. The cytogenetic pattern in pigs with hereditary intersexuality similar to the syndrome of testicular feminization in man. Docum. vet., Brno, 8, 71-82.

Ludvigien J., Basse A.. Clausen Hj., Jonsson P., 1963. Congenital paralysis of hindquarter in pigs (in Danish). In: Landøkonomisk Forsøgslaboratoriums efterårsmøde, Arbog 1963, 414-417, Danish National Institute of Animal Science, Copenhagen.

LUKaS J., 1953. Three-day sickness of baby pigs. J. Am. vet. med. Ass., 123, 214-216.

Lund C., Christensen I.D., WegGer I., 1980. Ascorbic acid metabolism in swine. Studies on ascorbic acid content in blood, milk and tissues (in Danish). Aarsberetn. Inst. Sterelitetsforsk., 1980, 48-60.

LUNDEHEIM M., 1979. Genetic analysis of respiratory diseases in pigs. Acta Agric. scand., 29, 209-215.

LUNDEHEIM N., JOHANSSON K., ANDERSSON K., 1980. Estimated phenotypic and genetic parameters based on data from the Swedish pig progeny testing stations. Acta Agric. scand. 30, $183-188$.

LUNDSTRÖM K., 1975. Genetic parameters estimated on data from the Swedish pig progeny testing with special emphasis on meat colour. Swedish J. agric. Res., 5, 209-221.

LUNNEY J.K., SACHS D.H., 1979. Transplantation in miniature swine. V. - Characterization of la antigens. J. Immun., 122, 623-627.

LUSH I.E., 1966. The biochemical genetics of vertebrates except man, 64-69. North-Holland Publishing Company, Amsterdam.

LUSH J.L., 1921. Inheritance in swine. J. Hered., 12, 57-71.

LUSH J.L., 1936. Genetic aspects of the Danish system of progeny-testing swine. Iowa Agr. Exp. Sta. Res. Bull., 204.

Lush J.L., 1937. Animal Breeding Plans. Lowa State College Press. Ames, Iowa, U.S.A.

LYSTER R.L.J., 1972. Reviews of the progress of dairy science. Section C. Chemistry of milk proteins. J. Dairy Res., 39, 279-318.

Mabry J.W., Christian L.L., Kuhlers D.L., 1981. Inheritance of porcine stress syndrome. J. Hered., 72, 429-430.

MC Dermid E.M., Agar N.S., Chal C.K., 1975. Electrophoretic variation of red cell enzyme systems in farm animals. Anim. Blood Grps biochem. Genet., 6, 127-174.

MC FeE A.F., Banner M.W., 1969. Inheritance of chromosome number in pigs. J. Reprod. Fert., 18, 9-14.

MC FEe A.F., Banner M.W., RaRy J.M., 1966. Variation in chromosome number among european wild pigs. Cytogenetics, 5, 75-81.

MC Feely R.A., 1967. Chromosome abnormalities in early embryo of the pig. J. Reprod. Fert., 13, 579-581.

MC Gloughlin P., Ahern C.P., Butler M., MC Loughlin J.V., 1980. Halothane-induced malignant hyperthermia in Irish pigs. Livest. Prod. Sci., 7, 147-154.

MC Gloughlin P., MC Loughlin J.V., 1975. The heritability of $\mathrm{pH}_{\mid}$in Longissimus dorsi muscle in Landrace and Large White pigs. Livest. Prod. Sci., 2, 271-280.

MC LEAN J.A., 1914. The sapphire hog. J. Hered., 5, 301-304.

Mc Phee C.P., Brennan P.J., Duncalfe F., 1979. Genetic and phenotypic parameters of Australian Large White and Landrace boars performance-tested when offered food ad libitum. Anim. Prod., 28, 79-85.

MC Phee C.P., TakKen A., D'ARCy K.J., 1979. Genetic variation in meat quality and the incidence of the malignant hyperthermia syndrome in Large White and Landrace boars. Aust. J. exp. Agric. Anim. Husb., 19, 43-47.

MC Phee H.C., Russel E.Z., Zeller J., 1931. An inbreeding experiment with PolandChina swine. J. Hered., 22, 393-403.

McTaggart H.S., Laing A.H., Imlah P., Head K.W., Brownlie S.E., 1979. The genetics of hereditary lymphosarcoma of pigs. Vet. Rec., 105, 36. 
MAGEE W.T., 1951. Inheritance of scrotal hernia in swine. J. Anim. Sci., 10, 516-522.

Major F., Dinklage H., Gruhn R., 1970. Gene frequency of blood groups from different European Landrace pigs. In : XIth European Conference on Animal Blood Groups and Biochemical Polymorphism, 271-274, Polish Scientific Publishers, Warsaw.

Malmfors B., Nilsson R., 1979. Meat quality traits in Swedish Landrace and Yorkshire pigs with special emphasis on genetics. Acta Agric. scand., suppl. 21, 81-90.

MaLYNiCZ G.L., 1982. Complete polydactylism in Papua New Guinea village pig, with otocephalic homozygous monsters. Ann. Génét. Sél. anim., 14, 415-420.

MarTIN C.E., MC Dowell W.S., 1975. Lactation failure (mastitis-metritis-agalactia). In : DunNe H.W. and Leman A.D. (Eds), Diseases of Swine, Iowa State University Press, Ames, Iowa. U.S.A.

Martin R.H., Gobbl.e J.L., Harstock T.H., Graves H.B., Ziegler J.M., 1973. Characterization of an obese syndrome in the pig. Proc. Soc. exp. Biol. Med., 143, 198-203.

MASON I.L., 1969. A world dictionary of livestock breeds, types and varieties (2nd ed.), 149-177, Commonwealth Agricultural Bureaux, Farnham Royal, U.K.

Matoušek J., 1970. Polymorphic and antigenic substances in the fertility of farm animals (Review). Anim. Blood Grps biochem. Genet., 1, 213-228.

Mesnil du Buisson F. du. Millanvoye B., Bariteau F., Legault C., 1974. Facteurs de variation de la production et de la qualité de la semence du verrat : effets saisonniers, héritabilité, corrélations entre variables. In : Journées de la Recherche Porcine en France, 1974, 63-70, Institut Technique du Porc, Paris.

Meyer H., Drommer W., 1968. Erbliche Hypotrichie beim Schwein. Dt. tierärztl. Wschr., 75, 13-17.

Meyer H., Plonalt H., 1968. Uber eine erbliche Kalziumstoffwechselstörung beim Schwein (erbliche Rachitis). Zentbl. Vet.-Med., 15, 481-493.

Meyer H., Trautwein G., 1966. Experimentelle Untersuchungen über erbliche Meningocele cerebralis beim Schwein. Pathol. Veterin., Basel, 3, 529-542.

Meyer J., Buschmann H., Kräusslich H., 1982. Selection on antibody response in pigs. Ann. Génét. Sél. anim., 14, 96 (Abstr.).

MEYER J.N., 1973. Blood group and serum protein polymorphism in the Slovakian Large White pig. Anim. Blood Grps biochem. Genet., 4, 63-64.

MEYER J.N., VERHORST D., 1973. The evidence of erythrocyte acid phosphatase by starch gel electrophoresis in the pig. Anim. Blood Grps biochem. Genet., 4, 129-131.

Mikami H., Fredeen H.T., 1979. A genetic study of cryptorchidism and scrotal hernia in pigs. Can. J. Genet. Cytol., 21, 9-19.

Mikami H.,'Fredeen H.T., Sather A.P., 1977. Mass selection in a pig population. 2. - The effects of inbreeding within the selected populations. Can. J. Anim. Sci., 57, 627-634.

MILLER L.R., GaRwoOd V.A., JUDGE M.D., 1975. Factors affecting porcine muscle fiber type, diameter and number. J. Anim. Sci., 41, 66-77.

MiLOJIC M., 1966. Color inheritance when crossing certain pig breeds (in Serbo-croat). Zborn. Rad. pol'opriv. Fak. Univ. Beogr., 14, 1-13.

Minkema D., Eikelenboom G., van Eldik P., 1977. Inheritance of M.H.S.-susceptibility in pigs. In : Proceedings of the Third International Conference on Production Disease in Farm Animals, 203-207, Pudoc, Wageningen, The Netherlands.

MOLEnAar B.A.J., 1976. The relationship between inbreeding and meat quality in Piétrain pigs (in Dutch). Tijdschr. Diergeneesk., 101, 1380-1381.

Molénat M., Thibault B., 1977. Héritabilité du nombre de fausses tétines chez la truie. In: Journées de la Recherche Porcine en France 1977, 69-73, Institut Technique du Porc, Paris.

Monin G., Ollivier L., Sellier P., 1976. Etude du syndrome d'hyperthermie maligne chez le porc de Piétrain : premiers résultats. In : Journées de la Recherche Porcine en France 1976, 229-238, Institut Technique du Porc, Paris.

Monin G., Sellier P., Ollivier L., 1979. Etude de quelques caractéristiques sanguines de populations porcines françaises. Relations avec le syndrome d'hyperthermie maligne. Ann. Rech. vét., 10, 535-547. 
Monin G., Selilifr P., Ot.livier L., Goutefongea R., Girard J.P., 1981. Carcass characteristics and meat quality of halothane negative and halothane positive Pietrain pigs. Meat Sci., 5, 41.3-423.

Muir W.M., Rasmusen B.A., 1974. A combined estimate of recombination between the genes for $\mathrm{C}$ and $\mathrm{J}$ blood groups in pigs. Anim. Blood Grps biochem. Genet., 5, 133-135.

NAGEL E., SEIFERT H.. 1980. Zur Heritabilität röntgendiagnostich erfassbarer Osteochondropathien des Fleischschweines. Mh. Vet.-Med., 35, 698-699.

NeEly J.D., JOHNSON B.H., RoBISON O.W., 1980. Heterosis estimates for measures of reproductive traits in crossbred boars. J. Anim. Sci., 51, 1070-1077.

NEeTESON F.A., 1964. Some congenital defects in pigs (in Dutch). Tijdschr. Diergeneesk., 89, $1003-1010$.

Nielsen P.B., 1961. The M blood group system of the pig. Acta vet. scand., 2, $246-253$.

Nielsen P.B., 1966. Studies on the genetic relationship between the serum amylase system and other blood group systems in pigs. In : Polymorphismes Biochimiques des Animaux, 449-452. Institut National de la Recherche Agronomique, Paris.

NiElSEN P.B., 1972. Isoantigens of the immunoglobulins in pigs. Acta vet. scand., 13, $143-145$.

NiElsen P.B., Vogel.1 P., 1982. A new $\mathrm{Kd}$ subgroup designated $\mathrm{Kg}$ in the porcine $\mathrm{K}$ blood group system. Anim. Blood Grps biochem. Genet., 13, 65-66.

Nordby J.E., 1929. Congenital skin, ear and skull defects in a pig. Anat. Rec., 42, 267-280.

NordBy J.E., 1930. Congenital ear and skull defect in swine. J. Herẹ., 21, 499-501.

NORDBY J.E., 1932. Inheritance of whorls in the hair of swine. J. Hered., 23, 397-404.

NORDBY J.E., 1933. Congenital melanotic skin tumors in swine. J. Hered., 24, 361-364.

Nordby J.E., 1934 a. Congenital defects in the mammae of swine. J. Hered., 25, $499-502$.

NordBY J.E., 1934 b. Kinky tail in swine. J. Hered., 25, 171-174.

NordBy J.E., 1939. Inegalities in the digits of swine. J. Hered., 30, 307-310.

NORODD N., 1958. Hereditary abnormalities of the tongue, cleft palate and harelip in pigs (in Norwegian). Nord. Vet.-Med., 10, 625-643.

OGden A.L., 1961. Biochemical polymorphism in farm animals. Anim. Breed. Abstr., 29, $127-138$.

OISHI T., 1979. Blood groups and biochemical polymorphism in pigs and their application as genetic markers (in Japanese). Jap. J. zootech. Sci., 50, 345-355.

OIshi T., ABE T., 1979. Polymorphism of PHI, 6 PGD, PGM and ADA enzymes in porcine red cells. Bull. Nat. Inst. Anim. Ind., 35, 9-18.

Oishi T., AвE T., Komatsu T., 1979 a. Three serum allotypic antigens detected in pigs. Jap. J. zootech. Sci., 50, 173-181.

Oıshı T., EsAKı K., TOMiTA T., 1980 a. Genetic relationship among Göttingen miniature, European and East Asian pigs investigated from blood groups and biochemical polymorphism. Jap. J. zootech. Sci., 51, 226-228.

Oishi T., Kоматsu M., АвE T., 1979 b. Breed variations of gene frequencies in pig red cell PHI, 6 PGD, PGM and ADA enzyme systems and their availability for paternity test. Jap. J. zootech. Sci., 50, 879-884.

Oishi T., Nishoj H., Horiuchi A., Hyodo I., 1981. Practical values of the halothane, H, PHI and 6PGD loci for exclusion of PSE pork in Japanese Landrace pigs. Jap. J. zootech. Sci., 52, 586-594.

Oishi T., Tanaka K.. Noguchi H., 1978. Blood group and serum protein variations in Duroc breed and comparison of variations among several pig breeds in Japan (in Japanese). Jap. J. zootech. Sci., 49, 768-774.

OIshi T.,TомітA T., 1976. Blood groups and serum protein polymorphisms in the PitmanMoore and Ohmini strains of miniature pigs. Anim. Blood Grps biochem. Genet., 7, 27-32.

Oishi T.,Tomita T., Komatsu M., 1980 b. New genetic variants detected in the haemopexin and ceruloplasmin systems of Ohmini miniature pigs. Anim. Blood Grps biochem. Genet., 11, 59-62.

OLBRyCht T.M., 1941. Statistical analysis of black colour in Wessex Saddleback breed. Ann. Eugen., 11, 80-88. 
OlBRyCht T.M., 1944. Behaviour of some external characteristics in Essex pigs. J. agric. Sci., Camb., 34, 16-21.

Ollivier L., 1970. L'épreuve de la descendance chez le porc Large White français de 1953 à 1966. I. - Analyse de la variation. Ann. Génét. Sél. anim., 2, 311-324.

Ollivier L., 1980. Le déterminisme génétique de l'hypertrophie musculaire chez le porc. Ann. Génét. Sél. anim., 12, 383-394.

Ollivier L., 1981. Eléments de génétique quantitative, Masson, Paris.

Ollivier L., Derrien A., 1981. Une méthode générale d'estimation des paramètres génétiques dans un échantillon sélectionné, avec une application à une sélection sur un indice à 3 caractères. Ann. Génét. Sél. anim., 13, 281-292.

Ollivier L., Derrien A., Molenat M., 1981. Paramètres génétiques des femelles Large White et Landrace Français du contrôle de descendance sur la période 1970-1978. In : Journées de la Recherche Porcine en France 1981, 293-298, Institut Technique du Porc, Paris.

Ollivier L., Henry Y., 1978. Variation génétique de l'efficacité alimentaire chez le porc en croissance. Interactions avec les conditions nutritionnelles. Ann. Génét. Sél. anim., 10, 99-124.

Ollivier L., Mesle L., 1963. Résultats d'un contrôle de descendance portant sur la qualité de la viande chez le porc. Ann. Zootech., 12, 173-179.

Ollivier L., Sellier P., Monin G., 1975. Déterminisme génétique du syndrome d’hyperthermie maligne chez le porc de Piétrain. Ann. Génét. Sél. anim., 7, 159-166.

Ollivier L., Sellier P., Monin G., 1978. Fréquence du syndrome d'hyperthermie maligne dans des populations porcines françaises : relations avec le développement musculaire. Ann. Génét. Sél. anim., 10, 191-208.

OP'T HOF J., OsterhofF D.R., DE BEeR G., 1972. Polymorphism of sorbitol dehydrogenase and 6-phosphogluconate dehydrogenase in swine (Sus Scrofa). Anim. Blood Grps biochem. Genet., 3, 237-238.

Ossent H.P., 1929. Rezessives Weiss und Frischlingsstreifung der Mangalitza Schweine. Züchter, 1, 11-13.

OSTERHOFF D., 1956. Erblichkeitsuntersuchungen und Nachkommenprüfungen auf Grund der Ergebnisse der Schweinemastleistungsprüfungen. Z. Tierzücht. ZüchtBiol., 68, 199-240.

Palludan B., Wegger I., Moustgaard J., 1982. Quantitative biochemical genetics in swine. A study of ascorbic acid and some trace elements. In : 2nd World Congress on Genetics applied to Livestock Production, VIII, 498-504, Editorial Garsi, Madrid.

Parizek M., Kudelka E., Groch L., 1965. Heredity of defective nipples in sows and their transmission by breeding. Sb. vys. Sk. zemed. Brne Rada B, 13, 301-312.

Patterson D.S.P., Done J.T., 1977. Neuro-chemistry as a diagnostic aid in the congenital tremor syndrome of piglets. Br. vet. J., 133, $111-119$.

Patterson D.S.P., Sweasey D., Brush P.J., Harding J.D.J., 1973. Neurochemistry of the spinal cord in British Saddleback piglets affected with congenital tremor, type A IV, a second form of hereditary cerebrospinal hypomyelinogenesis. J. Neurochem., 21, 397-406.

Pazdera J., Hruban V., Hradecký J., Fortýn K., Staněk R., Pospišll M., Jílek M., 1981. Immunogenetic studies in semi-inbred pigs. Folia biol., Praha, 27, 96-106.

Pease A.H.R., Smith C., 1965. A note on the heritability of muscle colour in pigs. Anim. Prod., 7, 273-274.

Pennington L.R., Flye M.W., Kirkman R.L., Thistlethwaite J.R. Jr., Williams G.M., SACHS D.H., 1981 a. Transplantation in miniature swine. X. - Evidence for non-SLA-linked immune response gene(s) controlling rejection of SLA-matched kidney allografts. Transplantation, 32, 315-320.

Pennington L.R., Lunney J.K., SaChs D.H., 1981 b. Transplantation in miniature swine. VIII. - Recombination within the major histocompatibility complex of miniature swine. Transplantation, 31, 66-71.

Petrov A., 1974. A little known lethal character in pigs (in Bulgarian). Zhivotnovdni Nauki, 11, 75-79. 
Pfleiderer U.E., 1973. Genetische Parameter der wichtigsten Mastleistungs- und Schlachtkörpermerkmale aus der Stationsprüfung von Schweinen der Deutschen Landrasse. I. - Heritabilitätsschätzungen, Züchtungskunde, 45, 215-223.

Phillips R.W., Panepinto L.M., Will D.H., 1979. Genetic selection for diabetogenic traits in Yucatan miniature swine. Diabetes, 28, 1102-1107.

Planchenault D., Sellier P., Ollivier L., 1978. Le développement des cornets nasaux chez le Porc. Son appréciation, aspects génétiques. Ann. Biol. anim. Biochim. Biophys., 18, 211-218.

POND W.G., Houpt K.A., 1978. The Biology of the Pig, Comstock Publishing Associates, Ithaca, New York, U.S.A.

POPESCU C.P., 1982. Reciprocal translocations in pigs and their effects on performance. Pig News and Information, 3, 255-257.

Popescu C.P., Legault C., 1979. Une nouvelle translocation réciproque $t(4 q+; 14 q-)$ chez le porc domestique (Sus scrofa domestica). Ann. Génét. Sél. anim., 11, 361-369.

POPESCU C.P., QUÉRÉ J.P., FRANCESChI P., 1980. Observations chromosomiques chez le sanglier français (Sus scrofa scrofa). Ann. Génét. Sél. anim., 12, 395-400.

Pretorius A.M.G., Schmid D.O., Cwik S., Meyer J., Albert E.D., 1977. PGM 3 locus and its genetic polymorphism in lymphocytes of the pig. J. Immunogenetics, 4, 363-365.

Przytulski T., Kocwin-Podsiadly M., Klemke A., 1982. Relationship between serum alkaline phosphatase genetic polymorphism and activity of the enzyme in Large White pigs. Ann. Génét. Sél. anim., 14, 43-48.

Przytulski T., Porzeczkowska D., 1976. Polymorphism of blood serum amylase and leptospirosis of pigs of Large White Polish breed. Theor. Appl. Genet., 48, 237-242.

Przytulski T., Porzeczkowska D., 1979. Serum proteins and enzyme polymorphism and leptospirosis of pigs of Polish Large White breed. Ann. Génét. Sél. anim., 11, 121-125.

PRZyTUlski T., PORzeczkowska D., 1980. Studies on genetic resistance to leptospirosis in pigs. Br. vet. J., 136, 25-32.

PufF H., 1975. Genetische parameter wichtiger Mast- und Schlachtleistungskriterien bei der Zuchtpopulation der Deutschen Landrasse in Niederbayern. Bayer. landw. Jb., 52, 956-975.

Pumfrey R.A., Johnson R.K., Cunningham P.J., Zimmerman D.R., 1980. Inheritance of teat number and its relationship to maternal traits in swine. J. Anim. Sci., 50, 1057-1060.

RADOVIC B.M., 1974. Polymorphism of transferrin and some productive properties of white swine (in Serbo-croat). Acta vet., Beogr., 24, 175-182.

Radzikowsky A., Meyer J., Buschmann H., Averdunk G., Blendl H.M., Osterkorn K., 1974. Zur Variation der Immunantwort bei mehreren Schweinerassen. I. - Mitteilung: variation der Immunantwort gegenüber Schaferythrozyten. Z. Tierzücht. ZüchtBiol., 91, 59-74.

RAPACZ J., 1974. Immunogenic polymorphism and genetic control of low density beta-lipoprotein in swine. In : Ist World Congress on Genetics applied to Livestock Production, I, 291-298, Editorial Garsi, Madrid.

RAPACZ J., 1982. Current status of lipoprotein genetics applied to livestock production in swine and other domestic species. In : 2nd World Congress on Genetics applied to Livestock Production, VI, 365-374, Editorial Garsi, Madrid.

Rapacz J., Grummer R.H., Hasler J., Shackelford R.M., 1970. Allotype polymorphism of low density $\beta$-lipoproteins in pig serum (LDLpp1, LDLpp2). Nature, Lond., 5236, 941-942.

RAPACZ J., HaSLER-RaPACZ J., 1974. Linkage between genes for different heavy-chain immunoglobulin allotypes in swine and cattle. Anim. Blood Grps biochem. Genet., 5 (suppl. 1), 33-34.

RaPaCz J., Hasler-Rapacz J., 1980. Allotypic polymorphism and genetic relation of five lipoprotein systems in swine. Anim. Blood Grps biochem. Genet., 11 (suppl. 1), 59 (Abstr.).

RAPACZ J., HASLER-RAPACZ J., 1982. Immunogenetic studies on polymorphism, postnatal passive acquisition and development of immunoglobulin gamma (IgG) in swine. In : 2nd World Congress on Genetics applied to Livestock Production, VIII, 601-606, Editorial Garsi, Madrid.

Rapacz J., Hasler-Rapacz J., KuO W.H., 1978. Immunogenetic polymorphism of lipoproteins in swine. 2. - Five new allotypic specificities (Lpp6, Lpp11, Lpp12, Lpp13 and Lpp14) in the Lpp system. Immunogenetics, 6, 405-424. 
RaPaCz J., HaSler-RapaCz J., Kuo W.H., L D., 1976. Immunogenetic polymorphism of lipoproteins in swine. 1. - Four additional serum $\beta$-lipoprotein allotypes (Lpp2, Lpp4, Lpp5 and Lpp 15) in the Lpp system. Anim. Blood Grps biochem. Genet., 7, 157-177.

RASMUSEN B.A., 1963. Irregularities in transmission of $\mathrm{E}$ alleles in pigs. Immunogenetics Letter, 3, 31-32.

RASMUSEN B.A., 1964. Gene interaction and the A-O blood group system in pigs. Genetics, 50, $191-198$.

RASMUSEN B.A., 1965 a. Isoantigens of gamma globulin in pigs. Science, 148, 1742-1743.

RASMUSEN B.A., 1965 b. Linkage between the loci for C and J blood groups in pigs. Vox Sang., 10, 239-241.

RASMUSEN B.A., 1972. Gene interaction and the A-O and $\mathrm{H}$ blood-group systems in pigs. Anim. Blood Grps biochem. Genet., 3, 169-172.

RASMUSEN B.A., 1975 a. Blood-group alleles of domesticated animals. In : KING R.C. (Ed.), Handbook of Genetics, 4 : Vertebrates of genetic interest, 447-457, Plenum Press, New York and London.

RASmuSEn B.A., 1975 b. A and O blood types and reproduction in pigs. J. Anim. Sci., 41, 256 (Abstr.).

RASMUSEN B.A., 1981. Linkage of genes for PHI, halothane sensitivity, A-O inhibition, H red blood cell antigens and 6-PGD variants in pigs. Anim. Blood Grps biochem. Genet., 12, 207-209.

RASMUSEN B.A., 1982. Linkage between genes at the $\mathrm{H}$ blood group locus and the loci for $\mathrm{C}$ and $\mathrm{J}$ blood groups in pigs. Anim. Blood Grps biochem. Genet., 13, in press.

Rasmusen B.A., Beece C.K., Christian L.L., 1980. Halothane sensitivity and linkage of genes for $\mathrm{H}$ red blood cell antigens, phosphohexose isomerase (PHI) and 6-phosphogluconate dehydrogenase (6-PGD) variants in pigs. Anim. Blood Grps biochem. Genet., 11, 93-107.

Rasmusen B.A., Christian L.L., 1976. H blood types in pigs as predictors of stress susceptibility. Science, 191, 947-948.

RASMUSEN B.A., HAGEN K.L., 1973. The H blood-group system and reproduction in pigs. J. Anim. Sci., 37, 568-573.

REED H.C.B., 1976. Pig artificial insemination and its future. In : Proceedings of the meeting and joint refresher course on pig reproduction, Aberdeen, october 1976, 67-75.

ReETz I., Feder H., 1974. Ceruloplasmin, Kupfer- und Eisengehalt im Blutplasma beim Schwein und ihre Beziehungen zu Leistungseigenschaften. In : Ist World Congress on Genetics applied to Livestock Production, III, 1159-1 164, Editorial Garsi, Madrid.

Reetz I., Wegner W., Feder H., 1975. Statistik, Erblichkeit und Korrelative Bindung einiger Merkmale des Kreislaufsystems bei weiblichen Mastschweinen der Deutschen Landrasse. II. - Erblichkeitsgrade und Genfrequenzen. Zentbl. Vet.-Met., 22, 741-755.

Renard C., Vaiman M., Capy P., Sellier P., 1982. Sla markers and characters of production in the pig. In : 2nd World Congress on Genetics applied to Livestock Production, VIII, 570-583, Editorial Garsi, Madrid.

Reutzel L.E., Sumption L.J., 1968. Genetic and phenotypic relationships involving age at puberty and growth rate in gilts. J. Anim. Sci., 27, 27-30.

REvelle T.J., RoBison O.W., 1973. An explanation for the low heritability of litter size in swine. J. Anim. Sci., 37, 668-675.

RHOAD A.O., 1934. Woolly hair in swine. J. Hered., 25, 371-375.

RiChTER F., SChARRER G., 1959. Auftreten von Knickschwanz beim Schwein. LandbForsch.Völkenrode, 9, 21-22.

RichTER L., Flock D.K., BiCKhardT K., 1973. Creatin-Kinase-test als Selektionsmerkmal zur Schätzung der Fleischbeschaffenheit im Rahmen der Eigenleistungsprüfung beim Schwein. Züchtungskunde, 45, 429-438.

RIMAILA-PÄRNäNEN E., 1982. Recessive mode of inheritance in progressive ataxia and incoordination in Yorkshire pigs. Hereditas, 97, 305-306.

RINGARP N., 1960. Clinical and experimental investigation into a post-parturient syndrome with agalactia in sows. Acta Agric. scand., 10, suppl. 7, 166 p. 
Roberts E., CARroll W.E., 1931. The inheritance of "hairlessness " in swine. Hypotrichosis II. J. Hered., 22, 125-132.

RobertS E., KRIDER J.L., 1949. Inheritance of red-eye in swine. J. Hered., 40, 306.

Roberts E., MorriLl C.C., 1944. Inheritance and histology of wattles in swine. J. Hered., 35, 149-151.

Rogdakis E., Strutz C., 1978. Phänotypische und genetische Parameter für den löstichen Proteingehalt im Schweinefettgewebe. Züchtungskunde, 50, 312-316.

RothsChild M.F., Chapman A.B., 1976. Factors influencing serum cholesterol levels in swine. J. Hered., 67, 47-48.

Rutter J.M., Burrows M.R., Sellwood R., Gibbons R.A., 1975. A genetic basis for resistance to enteric disease caused by E. Coli. Nature, Lond., 257, 135-136.

Ryley J.W., Melville E.L., Barker J.S.F., 1955. Foetal maldevelopment in a litter of Large White pigs. Queensland J. agric. Sci., 12, 61-68.

Safarova P., Karadjole I., Hyldgaard-Jensen J., Nielsen P.B., Lyeik G., 1972. Phosphoglucomutase polymorphism in porcine red cells. Acta vet. scand., 13, 134-136.

SAILER J., 1955. Epitheliogenesis imperfecta neonatorum sui beim Schwein. Tierärztl. Umsch., 10, 215-216.

SAISON R., 1967. Two new antibodies, anti- $\mathrm{N}_{\mathrm{b}}$ and anti- $\mathrm{N}_{\mathrm{c}}$, in the $\mathrm{N}$ blood group system in pigs. Vox Sang., 12, 215-220.

SAISON R., 1973. Red cell peptidase polymorphism in pigs, cattle, dogs and mink. Vox Sang., 25, $173-181$.

SAISON R., GibletT E.R., 1969. 6-Phosphogluconate dehydrogenase polymorphism in the pig. Vox Sang., 16, 514-516.

Saison R., Ingram D.G., 1962. A report on blood group in pigs. Ann. N.Y. Acad. Sci., 97, 226-232.

Saison R., O'Reilly M., 1971. Phosphohexose isomerase variants in pigs. Vox Sang., 20, 274-276.

SAISON R., Rasmusen B.A., HRadeckÝ J., 1967. Da, a factor in a new blood group system in pigs. Can. J. Genet. Cytol., 9, 794-798.

SCHEPER P., 1979. Influence of environmental and genetic factors on meat quality. Acta Agric. scand., suppl. 21, 20-31.

Schmid D.O., Buschmann H., 1966. A new blood group antigen in pigs. In : Polymorphismes Biochimiques des Animaux, 165, Institut National de la Recherche Agronomique, Paris.

SCHmid D.O., CwIK S., 1972. Soluble leukocyte antigens in serum of pigs. Tissue Antigens, 2, 255-261.

SCHMiDT D.V., EBNER K.E., 1972. Multiple forms of pig, sheep and goat $\alpha$-lactalbumin. Biochim. Biophys. Acta, 263, 714-720.

SChMidT J., LAUPRECht E., 1936. Beitrag zur Vererbung der Schweinefarben. Züchtungskunde, $11,1-21$.

Schmitten F., Schepers K.H., Wagner E., Trappmann W., 1981. Untersuchungen zur Diagnose der Stressanfälligkeit und ihrer Beziehungen zu Leistungseigenschaften beim Schwein. 4. - Schätzgung genetischer Parameter für Fleischqualitätsmerkmale und Stresskriteria bei Schweinen der Deutschen Landrasse. Züchtungskunde, 53, 245-252.

SChneIder A., Schwörer D., Blum J., 1980. Beziehung des Halothan-genotyps zu den Produktions- und Reproduktionsmerkmalen der Schweizerischen Landrasse. Ann. Génét. Sél. anim., 12, 417 (Abstr.).

SChneider J.F., Christian L.L., Kuhlers D.L., 1982. Crossbreeding in swine : genetic effects on pig growth and carcass merit. J. Anim. Sci., 54, 747-756.

SCHROFFEL J., 1965. Genetic determination of the serum "thread proteins " and the slow $\alpha_{2}$ globulin polymorphism in pigs. In : MATOUŠEK J. (Ed.), Blood Groups of Animals, 321-329, Publishing House of the Czechoslovak Academy of Sciences, Prague.

SCHWÖRER D., Blum J., 1977. Blasses, wässeriges Schweinefleisch : Voraussage mangelhafter Fleischbeschaffenheit bereits am lebenden Tier. Der Kleinviehzüchter, 25, 641-650. 
Schwörer D., Blum J., Rebsamen A., 1980. Parameters of meat quality and stress resistance of pigs. Livest. Prod. Sci., 7, 337-348.

SEARLE A.G.. 1968. Comparative genetics of coat colour in mammals, Logos Press, London.

SEibold H.R., Davis C.L., 1967. Generalized myositis ossificans (familial) in pigs. Pathologia Vet., 4, 79-88.

Seifert H.. SChONmUth G., NAGEl E., 1971. Ergebnisse experimenteller Untersuchungen auf Wirkung genetischer Faktoren bei der Rhinitis atrophicans suum. Wiss. Z. Humboldt-Univ. Berlin, 20, 371-387.

Sellier P., 1970. Hétérosis et croisement chez le porc (revue bibliographique). Ann. Génét. Sél. anim., 2, 145-207.

Sellier P., 1974. Le croisement dans l'espèce porcine. In : Ist World Congress on Genetics applied to Livestock Production, I, 859-87I, Editorial Garsi, Madrid.

Sellier P., 1976. The basis of crossbreeding in pigs ; a review. Livest. Prod. Sci., 3, 203-226.

Sellier P., Ollivier L., 1982. Etude génétique du syndrome de l'abduction des membres (splayleg) chez le porcelet nouveau-né. I. - Modèle multifactoriel à un seuil. Ann. Génét. Sél. anim., 14, 77-92.

SIfRS D.G., ThOMSON G.M., 1972. Heritabilities and genetic correlations of carcass and growth traits in swine. J. Anim. Sci., 35, 311-316.

SIMON M., HOJNY J., 1972. A study of lymphocyte antigens in pigs by means of anti-erythrocyte reagents. In : Kovács G. and PAPP M. (Eds), XIIth European Conference on Animal Blood Groups and Biochemical Polymorphism, 369-374, Akadémiai Kiadó, Budapest.

Simon M., Hruban V., 1971. Lymphocyte typing in pigs : evidence for antigen L1. Anim. Blood Grps biochem. Genet., 2, 95-100.

Simon M.. Hruban V., 1972. Cytotoxic action of pig anti-A erythrocyte antibodies. Vox Sang., 23, 208-211.

SIMPSON Q.I., SiMPSON J.P., 1908. Genetics in swine hybrids. Science, 27, 941.

SitTMAn K.. 1973. Scrotal hernia in boars, a sex-limited trait with sex-modified fitness. Genetics, 74 (2, Pt 2), 257-258.

Sittman K.. Breeuwsma A.J., te Brake J.H.A., 1980. On the inheritance of intersexuality in swine. Can. J. Genet. Cytol., 22, 507-527.

Sittman K., Woodhouse H., 1977. Sex-limited and sex-modified genetic defects in swine - Cryptorchidism. Can. J. Genet. Cytol., 19, 487-502.

SKJERVOLD H., 1963. Inheritance of teat number in swine and the relationship to performance. Acta Agric. scand., 13, 323-333.

Skladanowska E., Zurkowski M., Wiatroszak I., Filipiak W., 1979. Polymorphism of the serum proteins of wild pigs. Anim. Blood Grps biochem. Genet., 10, 151-154.

Smith A.D. Buchanan, Robinson O.J., BRYANT D.M., 1938. The genetics of the pig. Bibliogr. genet., 12, $1-160$.

Sмiтн C., 1966. A note on the heritability of leg weakness scores in pigs. Anim. Prod., 8, 345-348.

Smith C., Bampton P.R., 1977. Inheritance of reaction to halothane anaesthesia in pigs. Genet. Res., 29, 287-292.

Smith C., Jensen E.L., Baker L.N., Cox D.F., 1968. Quantitative studies on blood group and serum protein systems in pigs. I. - Segregation ratios and gene frequencies. J. Anim. Sci., 27, 848-855.

Smith C., King J.W.B., Gilbert N., 1962. Genetic parameters of British Large White bacon pigs. Anim. Prod., 4, 128-143.

SMITH C., Ross G.J.S., 1965. Genetic parameters of British Landrace bacon pigs. Anim. Prod., 7, 291-301.

Smith H.J., Stevenson R.G., 1973. Congenital hydrocephalus in swine. Can. vet. J., 14, 311-312.

SMITH M.W., SMith M.H., Brisbin I.I. Jr., 1980. Genetic variability and domestication in swine. J. Mammal., 61, 39-45. 
SMithies O., 1955. Zone electrophoresis in starch gels : group variations in the serum proteins of normal human adults. Biochem. J., 61, 629-641.

Sonnenbrodt A., 1944. Untersuchungen über Epilepsie bei Schweinen. Dt. tierärztl. Wschr., 52, 250-255.

SPILlmaN W.J., 1906. Inheritance of coat colour in swine. Science, 24, 441-443.

Spillman W.J., 1907. Inheritance of the belt in Hampshire swine. Science, 25, 541-543.

SPOONER R.L., 1974. The relationships between marker genes and production characters in cattle, sheep and pigs. In : Ist World Congress on Genetics applied to Livestock Production, I, 267-271, Editorial Garsi, Madrid.

Standal N., Vold E., Trygstad O., Foss I., 1973. Lipid mobilization in pigs selected for leanness or fatness. Anim. Prod., 16, 37-42.

STAUN H., 1972. The nutritional and genetic influence on number and size of muscle fibres and their response to carcass quality in pigs. Wld Rev. Anim. Prod., 8 (3), 18-25.

Staun H., Jensen P., 1974. Genetic aspects of meat quality in pigs. In : Ist World Congress on Genetics applied to Livestock Production, I, 885-892, Editorial Garsi, Madrid.

Steinicke O., Nielsen A., 1959. Histological changes of the myenteric plexus of stomach in «baby pig disease ». Nord. Vet.-Med., 11, 399-429.

Stewart R.W., Selby L.A., Edmonds L.D., 1972. A survey of cranium bifidum : an inherited defect in swine. Vet. Med. small Anim. Clinician, 67, 677-678-681.

Stormont C.J., 1970. Isozyme polymorphism of the blood. In: XIth European Conference on Animal Blood Groups and Biochemical Polymorphism, 53-66, Polish Scientific Publishers, Warsaw.

Stormorken H., Svenkerud R., Slagsvold P., Lie H., Lundevall J., 1963. Thrombocytopenic bleedings in young pigs due to maternal isoimmunization. Nature, Lond., 198, 1116-1117.

STRANG G.S., KING J.W.B., 1970. Litter productivity in Large White pigs. II. - Heritability and repeatability estimates. Anim. Prod., 12, 235-243.

Strang G.S., Smith C., 1979. A note on the heritability of litter traits in pigs. Anim. Prod., 28, 403-406.

Stratil A., Glasnak V., Skladanowska E., Fésus l., Palovics Á., 1982. A comparison of the fastest-moving transferrin variants of the pig. Anim. Blood. Grps biochem. Genet., 13, 59.

Stromberg M.W., 1975. Myoclonia congenita. In : Dunne M.W. and Leman A.D. (Eds), Diseases of Swine, Iowa State University Press, Ames, Iowa, U.S.A.

StruTz C., Rogdakis E., 1979. Phenotypic and genetic parameters of NADPH-generating enzymes in porcine adipose tissue. Z. Tierzücht. ZüchtBiol., 96, 170-185.

Swatland H.J., 1974. Developmental disorders of skeletal muscle in cattle, pigs and sheep. Vet. Bull., 44, 179-202.

SWiger L.A., 1981. Personal communication.

SWIGer L.A., ISL.ER G.A., Harvey W.R., 1979. Postweaning genetic parameters and indexes for swine. J. Anim. Sci., 48, 1096-1100.

SYbesma W., EikelenboOm G., 1978. Methods of predicting pale, soft, exudative pork and their application in breeding programmes. A review. Meat. Sci., 2, 79-90.

SYSA P.S., 1980. Polymorphism of metaphase chromosomes in swine (Sus scrofa L.). Genetica, 52/53, 312-315.

Szent-IVanyi I.T., Szabo S., 1953. Untersuchungen über die Ursache der hämolytischen Gelbsucht der neugeborenen Ferkel. Acta vet. hung., 3, 75-80.

Szymanowski Z., Stetkiewicz S., Wachler B., 1926. Les groupes sérologiques dans le sang du porc et leur relation avec les groupes du sang humain. C. r. Séanc. Soc. Biol., 94, 204-205.

Takahashi A., Tanaka H., Tamada S., Shibata H., Inagaki J., 1974. Genetic variations of pancreatic proteinase in pigs (in Japanese). Research Bulletin of the Aichi-Ken Agricultural Research Center, series E, 4, 27-32.

Tanaka K., Kurosawa Y., Kurosawa K., Oishi T., 1980. Genetic polymorphism of erythrocyte esterase-D in pigs. Anim. Blood Grps biochem. Genet., 11, 193-197. 
Tariverdian G., 1970. Zur Populationsgenetik der Phosphohexoseisomerase (E.C. : 5.3.1.9) beim Schwein. Humangenetik, 9, 110-112.

TeOdoreanU N.I., 1935. Vererbungsbeobachtungen über die Farbe des roten und des schwarzen Mangaliczaschweines. Anal. Acad. Române (Men. Sect. Stiint.), 10, Men. 11, 20 p.

Tikhonov V.N., Gorelov I.G., Troshina A.I., 1972. Immunogenetic studies of wild European, Asian and American Suiformes in connection with the origin of some antigens in Sus Scrofa domestica. Anim. Blood Grps biochem. Genet., 3, 173-177.

Tikhonov V.N., Ratiany D., 1973. Blood group gene frequency differences between European and Asian pigs and their hybrids. Anim. Blood. Grps biochem. Genet., 4, 181-182.

Tikhonov V.N., Troshina A.I., 1975. Chromosome translocations in the karyotypes of wild boars Sus scrofa L. of the european and asian areas of U.S.S.R. Theor. Appl. Genet., 45, 304-308.

Tikhonov V.N., Troshina A.I., Gorelov I.G., 1974. Immunogenetical studies of European, Asian and American wild suiformes in connection with phylogenesis of domestic pigs. In : Ist World Congress on Genetics applied to Livestock Production, III, 197-202, Editorial Garsi, Madrid.

TiKhonov V.N., VAldman S.M., SAVina M.A., 1970. Immunogenetic study of allotypes of pig serum proteins using isoprecipitins. In : XIth European Conference on Animal Blood Groups and Biochemical Polymorphism, 307-309, Polish Scientific Publishers, Warsaw.

Triebler G., Engelman U., Kempe W., Kirchrof H., 1974. Die züchterisch-ökonomische Bedeutung von Erbfehlern und genetisch bedingten Defekten beim Schwein. Wiss. $Z$. Humboldt-Univ. Berlin, 23, 399-407.

Tripathi V.N., Howell W.E., 1969. Association of serum hemopexin, transferrin, prealbumin and albumin ${ }_{1}$ types with productive traits of Yorkshire and Lacombe breeds of pigs. Can. J. Anim. Sci., 49, 223-229.

Tripathi V.N., Howell W.E., 1974. The relationship of transferrin types with reproductive traits of Lacombe pigs. Indian vet. J., 51, 315-322.

Trolldenier H., 1964. Multiple Missbildungen mit Gesichtsspalten beim Deutschen Veredelten Landschwein. Fortpfl. Besam. Haustiere, 1, 55-72.

Urban W.E., Shelby C.E., Chapman A.B., Whatley J.A., Garwood V.A., 1966. Genetic and environmental aspects of litter size in swine. J. Anim. Sci., 25, 1148-1153.

VAIMAN M., 1974. Le complexe d'histocompatibilité majeur SL-A du porc. In : 1 st World Congress on Genetics applied to Livestock Production, I, 273-290, Editorial Garsi, Madrid.

Vaiman M., Chardon P., Renard C., 1979. Genetic organization of the pig SLA complex. Studies on nine recombinants and biochemical and lysostrip analysis. Immunogenetics, 9, 353-361.

Vaiman M., Fellous M., Wiels J., Renard C., Lecointre J., Mesnil du Buisson F. du, DAUSSET J., 1978 a. Presence of SLA and Ia-like antigen on boar spermatozoa. J. Immunogenetics, 5, 135-142.

Vaiman M., Haag J., ARnoux A., Nizza P., 1973. The histocompatibility complex SL-A in the pig. Possible recombination between the regions governing MLR and serology respectively. Tissue Antigens, 3, 204-211.

Vaiman M., HauptManN G., Mayer S., 1978 b. Influence of the major histocompatibility complex in the pig (SLA) on serum haemolytic complement levels. J. Immunogenetics, $5,59-65$.

Vaiman M., Metzger J.J., Renard C., Vila J.P., 1978 c. Immune response gene(s) controlling the humoral anti-lysozyme response (Ir-Lys) linked to the major histocompatibility complex SL-A in the pig. Immunogenetics, 7, 231-238.

VAiman M., Renard C., 1980. Deficit of piglets homozygous for the SLA histocompatibility complex in families. Anim. Blood Grps biochem. Genet., 11 (suppl. 1), 57 (Abstr.).

Vaiman M., Renard C., La Fage P., Ameteau J., Nizza P., 1970. Evidence for a histocompatibility system in swine (SL-A). Transplantation, 10, 155-164.

Vaiman M., Renard C., La Fage P., Ameteau J., Nizza P., 1971. Détermination d'un système d'histocompatibilité chez le porc (Sus scrofa): le système SL-A. Ann. Biol. anim. Biochim. Biophys., 11, 41-54. 
Vaiman M., Renard C., Ponceau M., Lecointre J., Villiers P.A., 1975. Alloantigènes sous la dépendance de la région SL-A contrôlant la réaction lymphocytaire mixte chez le porc. C. r. hebd. Séanc. Acad. Sci., Paris, 280, 2809-2812.

Valenta M., HyldgaARd-Jensen J., MoustgaARD J., 1967. Three lactic-dehydrogenase isoenzyme systems in pig spermatozoa and the polymorphism of sub-units controlled by a third locus C. Nature, Lond., 216, 506-507.

Veijalainen P., Rimaila-Parnänen E., 1978. A case of chromosomal polymorphism in an inbred Yorkshire pig. Hereditas, 88, 276-279.

VENEV I., 1977. The incidence and genetic determination of cratered teats in pigs (in Bulgarian). Zhivotnovdni Nauki, 14, 65-71.

Verhorst D., 1973. Polymorphism in glucose-6-phosphate dehydrogenase in the German Large White. Anim. Blood Grps biochem. Genet., 4, 65-68.

Verhorst D., Meyer J.N., Groeneveld E., Glodek P., 1974. Genetische Differenzierung zwischen Schweine-Zuchtlinien an Hand von Blut- und Enzympolymosphismen. In : Ist World Congress on Genetics applied to Livestock Production, III, 275-281, Editorial Garsi, Madrid.

Vögeli P., Nielsen P.B., Schwörer D., 1980. Studies on biochemical genetics in Swiss pig breeds : relation between blood parameters and meat quality traits. Anim. Blood Grps biochem. Genet., 11 (suppl. 1), 10-11 (Abstr.).

VÖgelı P., SCHWÖRER D., 1982. Kopplungsungleichgewicht zwischen dem Malignen Hyperthermie Syndrom (MHD, Halothanempfindlichkeit) und den Phänotypen des H-Blutgruppensystems und des PHI-Enzymsystems beim Schweizerischen Veredelten Landschwein. Züchtungskunde, 54, 124-130.

Vogt D.W., ARaKaki D.S., Brooks C.C., 1974. Reduced litter size associated with aneuploid cell lines in a pair of full-brother Duroc boars. Am. J. vet. Res., 35, 1127.1130.

VoRON P.P., SOKOLENKo N.T., 1971. Further studies on the F-system of blood groups in pigs. Genetika, 7, 58-61.

Walstra P., Minkema D., Sybesma W., van De Pas J.G.C., 1972. Genetic aspects of meat quality and stress resistance in experiments with various breeds and breed crosses. Ann. Génét. Sél. anim., 4, 133 (Abstr.).

Walther A.R., Prüfer J., Carstens P., 1932. Beitrag zur Kenntnis der Vererbungserscheinungen beim Schwein. Züchter, 7, 178-184.

WARD P.S., 1978. The splayleg syndrome in new-born pigs : a review. Vet. Bull., 48, 279-295, 381-399.

WARwick B.L., 1926. A study of hernia in swine. Wisc. Agric. Exp. Sta. Res. Bull., 69, 1-27.

Warwick E.J., Chapman A.B., Ross B., 1943. Some anomalies in pigs. J. Hered., 34, 349-352.

Watanabe S., Akita T., Koishikawa T., Naito M., Himeno K., 1979. Association between halothane reactivity and PHI phenotypes, and its significance for predicting meat quality in Japanese Landrace pigs. Jap. J. zootech. Sci., 50, 574-581.

Webb A.J., 1981. The halothane sensitivity test. In : Frøystein T., Slinde E. and Standal N. (Eds), Porcine stress and meat quality: causes and possible solutions to the problems, 105-124, Agricultural Food Research Society, Ås, Norway.

WeBB A.J., JoRDAN C.H.C., 1978. Halothane sensitivity as a field test for stress-susceptibility in the pig. Anim. Prod., 26, 157-168.

Webb A.J., Carden A.E., SMith C., Imlah P., 1982. Porcine stress syndrome in pig breeding. In : 2nd World Congress on Genetics applied to Livestock Production, V, 588-608, Editorial Garsi, Madrid.

WEBB A.J., RuSSELl W.S., 1981. Genetic association between leg weakness and performance traits in pigs. Anim. Prod., 32, 360 (Abstr.).

Wegger I., 1978. Plasma cholesterol in swine. Genetic variations and relation to alkaline phosphatase. Acta vet. scand., 19, 469-471.

Wellmann G., 1953.. Beobachtungen über die Bauchflechte (Pityriasis rosea) der Ferkel und die Erblichkeit der Disposition dazu. Tierärztl. Umsch., 8, 292-294.

Wells G.A.H., PINSENT P.J.N., Todd J.N., 1980. A progressive, familial myopathy of the Piétrain pig : the clinical syndrome. Vet. Rec., 106, 556-558. 
Weniger J.H., Steinhauf D., Glodek P., 1970. Meat quality as a selection criterion in the pig. Z. Tierzücht. ZüchtBiol., 87, 230-239.

W.ENTWORTH E.N., LUSH J.L., 1923. Inheritance in swine. J. agric. Res., 23, 557-582.

WiatroszaK I., 1970. Studies on blood groups in wild boar. In : XIth European Conference on Animal Blood Groups and Biochemical Polymorphism, 265-270, Polish Scientific Publishers, Warsaw.

WiatroszaK I., 1974. Study on correlation between blood groups and some productive characteristics in pig. Genet. pol., 15, 101-106.

WIDAR J., ANSAY M., 1975. Adenosine deaminase in the pig: tissue specific patterns and expression of the silent $A D A^{o}$ allele in nucleated cells. Anim. Blood Grps biochem. Genet., 6, $109-116$.

Widar J., AnSay M., Hanset R., 1974. Polymorphism of adenosine deaminase in the pig: allelic variation in erythrocytes. Anim. Blood Grps biochem. Genet., 5, 115-124.

WidAR J., ANSAY M., HANSET R., 1975. Allozymic variation as an estimate of heterozygosity in Belgian pig breeds. Anim. Blood Grps biochem. Genet., 6, $221-234$.

WIERZBOWSKI S., 1959. Impotentia of a hereditary nature in boars (in Polish). Medycyna wet., 15, 365.366.

WIESNER E., WILLER S., 1974. Veterinärmedizinische Pathogenetik. Gustav Fisher Verlag, Jena, G.D.R.

Wiggins E.L., Cassida L.E., Grummer R.H., 1950. The incidence of female genital abnormalities in swine. J. Anim. Sci., 9, 269-276.

Wijeratne W.V.S., Beaton D., Cuthbertson J.C., 1974. A field occurrence of congenital meningoencephalocoele in pigs. Vet. Rec., 95, 81-84.

WiJeratNe W.V.S., Wells G.A.H., 1980. Inherited renal cysts in pigs. Results of breeding experiments. Vet. Rec., 107, 484-488.

Willeke H., Claus R., Pirchner F., Alsing W., 1980. A selection experiment against $5 \alpha$ Androst-16-en-3-one, the boar taint steroid, in adipose tissue of boars. Z. Tierzücht. ZüchtBiol., 97, 86-94.

WILler S., NeufFer K., 1970. Phänotyp- und Genfrequenzen polymorpher Serumproteine beim Schwein. Arch. Exp. Vet., 24, 1071-1076.

Williams C.H., Shanklin M.D., Hedrick H.B., Muhrer M.E., Stubbs D.H., Krause G.F., PAYNe C.G., Benedict J.D., Hutcheson D.P., LASLEy J.F., 1978. The fulminant hyperthermia-stress syndrome : genetic aspects, hemodynamic and metabolic measurements in susceptible and normal pigs. In : Aldrete J.A. and BritT B.A. (Eds), Second International Symposium on Malignant Hyperthermia, 113-140, Grune and Stratton, New York.

WILSON E.R., JOHNSON R.K., WETTEMANN R.P., 1977. Reproductive and testicular characteristics of purebred and crossbred boars. J. Anim. Sci., 44, 939-947.

Wohlfarth E., 1961. Beitrag zum Akrosom-Defekt im Ebersperma. Zuchthyg. FortpflStör. Besam. Haustiere, 5, 268-274.

Wohlfarth E., 1964. Der Hodenhypoplasie beim Eber. Mh. Vet.-Med., 19, Sonderh. S 56.

Wohlfarth E., Seffner W., 1968. Die Hodenhypoplasie. Fortpfl. Besam. Haustiere, 4, 309-327.

Wrathall A.E., Bailey J., Wells D.E., Hebert C.N., 1977. Studies on the barker neonatal respiratory distress syndrome in the pig. Cornell Vet., 67, 543-598.

WRIGHT S., 1918. Color inheritance in mammals. VIII. - Swine. J. Hered., 9, 33-38.

Wyllie D., Morton J.R., OWEn J.B., 1979. Genetic aspects of voluntary food intake in the pig and their association with gain and food conversion efficiency. Anim. Prod., 28, 381-390.

Yamashita C., Shimazaki H., Miyake T., Saitoh M., Saheki Y., Ishitani R., 1980. Congenital porphyria in swine. Jap. J. vet. Sci., 42, 353-359.

Young L.D., Johnson R.K., Omtvedt I.T., Walters L.E., 1976. Postweaning performance and carcass merit of purebred and two-breed cross pigs. J. Anim. Sci., 42, 1124-1132.

Young L.D., Pumfrey R.A., Cunningham P.J., Zimmerman D.R., 1978. Heritabilities and genetic and phenotypic correlations for prebreeding traits, reproductive traits and principal components. J. Anim. Sci., 46, 937-949. 